\title{
A review and evaluation of multi-sectoral response services ('one- stop centers') for gender-based violence in Kenya and Zambia
}

\author{
Jill Keesbury \\ Population Council \\ Washington Onyango-Ouma \\ Chi-Chi Undie \\ Population Council \\ Catherine Maternowska \\ Frederick Mugisha
}

See next page for additional authors

Follow this and additional works at: https://knowledgecommons.popcouncil.org/departments_sbsr-rh

Part of the Domestic and Intimate Partner Violence Commons, International Public Health Commons, Maternal and Child Health Commons, and the Women's Health Commons How does access to this work benefit you? Let us know!

\section{Recommended Citation}

Keesbury, Jill, Washington Onyango-Ouma, Chi-Chi Undie, Catherine Maternowska, Frederick Mugisha, Emmy Kageha, and lan Askew. 2012. "A review and evaluation of multi-sectoral response services ('onestop centers') for gender-based violence in Kenya and Zambia." Nairobi: Population Council. 


\section{Authors}

Jill Keesbury, Washington Onyango-Ouma, Chi-Chi Undie, Catherine Maternowska, Frederick Mugisha, Emmy Kageha, and lan Askew 


\section{A REVIEW AND EVALUATION OF MULTI- SECTORAL RESPONSE SERVICES (“ONE-STOP CENTERS") FOR GENDER- BASED VIOLENCE IN KENYA AND ZAMBIA}

JILL KEESBURY, W. ONYANGO-OUMA, CHI-CHI UNDIE, CATHERINE MATERNOWSKA, FREDERICK MUGISHA, EMMY KAGEHA, IAN ASKEW 


\section{(1) Population Council}

The Population Council confronts critical health and development issues-from stopping the spread of HIV to improving reproductive health and ensuring that young people lead full and productive lives. Through biomedical, social science, and public health research in 50 countries, we work with our partners to deliver solutions that lead to more effective policies, programs, and technologies that improve lives around the world. Established in 1952 and headquartered in New York, the Council is a nongovernmental, nonprofit organization governed by an international board of trustees.

Population Council

Nairobi Office

General Accident Insurance House, 2 ${ }^{\text {nd }}$ Floor

Ralph Bunche Road, Upper Hill

P. O. Box 17643-00500

Nairobi

Kenya

Main Tel: +254 $202713480-3$

Fax: +254202713479

www.popcouncil.org

Suggested citation: Jill Keesbury, W. Onyango-Ouma, Chi-Chi Undie, Catherine Maternowska, Frederick Mugisha, Emmy Kageha, Ian Askew. 2012. A Review and Evaluation of Multi-Sectoral Response Services ("One-Stop Centers") for Gender-Based Violence in Kenya and Zambia. Population Council: Nairobi, Kenya.

(C) 2012 The Population Council, Inc. 


\section{A REVIEW AND EVALUATION OF MULTI- SECTORAL RESPONSE SERVICES (“ONE-STOP CENTERS") FOR GENDER- BASED VIOLENCE IN KENYA AND ZAMBIA}

Jill Keesbury, W. Onyango-Ouma, Chi-Chi Undie, Catherine Maternowska, Frederick Mugisha, Emmy Kageha, Ian Askew 


\section{ACKNOWLEDGMENTS}

This report is based on a study funded by the Eastern and Southern Africa Regional Office of the United Nations Children's Fund.

We are indebted to the administration of all the health facilities and one-stop centers that formed a part of this study, as well as to all the study's interviewees. We also gratefully acknowledge the varied contributions of several individuals toward the initiation and/or completion of the study, including: Dr. Felix Masiye, Grace Chiyaba, Dr. Harriet Birungi, Dr. Ian Kanyanya, Lucy Nganga, Winnie Osulah, Janet Munyasya, Memory Sichizuwe, Joseph Simbaya, Stephanie Topp, Christine Munalula, Clara Sommarin, Mendy Marsh, and Leigh Stefanik. 


\section{TABLE OF CONTENTS}

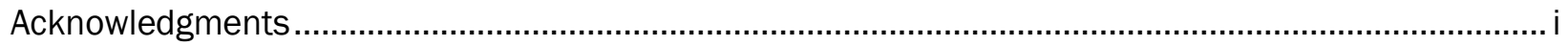

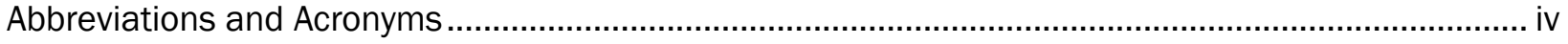

Executive Summary ......................................................................... Error! Bookmark not defined.

Introduction ...................................................................................... Error! Bookmark not defined.

The 'one-stop center' approach to SGBV response.......................................................................

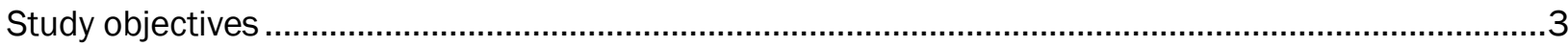

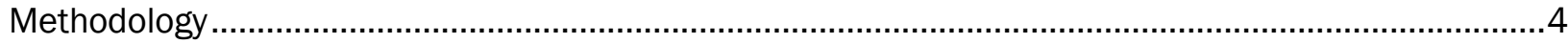

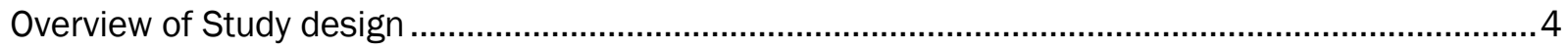

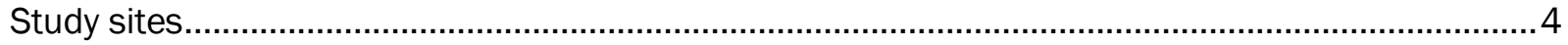

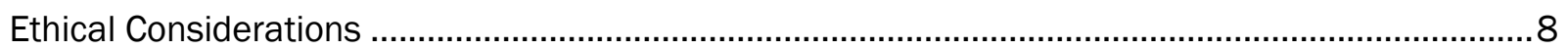

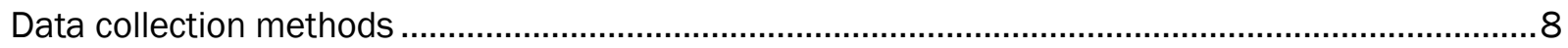

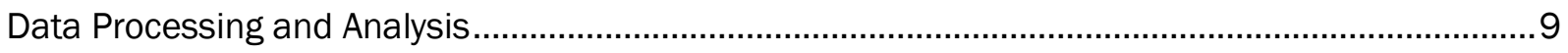

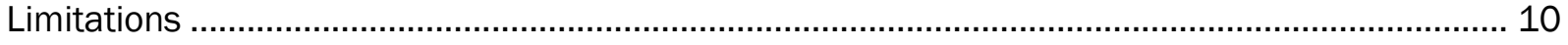

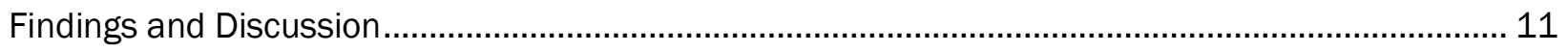

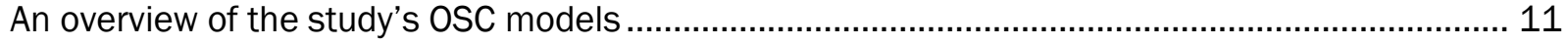

Effectiveness of OSC models in addressing the short and long-term health needs of survivors.... 12

Acceptability and effectiveness of the different OSC models in addressing health outcomes....... 16

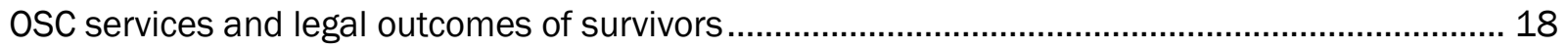

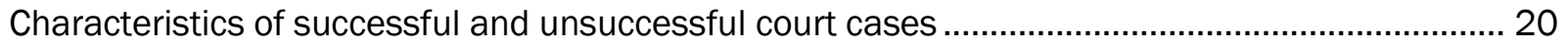

Acceptability of the different OSC models to survivors and caregivers in addressing legal outcomes21

Acceptability of different OSC models to key stakeholders ............................................................ 22

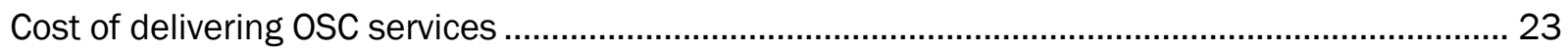

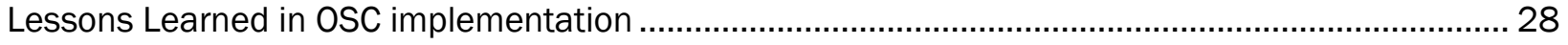

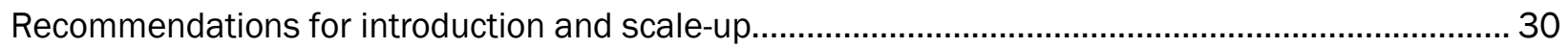

Conclusion ............................................................................................ Error! Bookmark not defined.

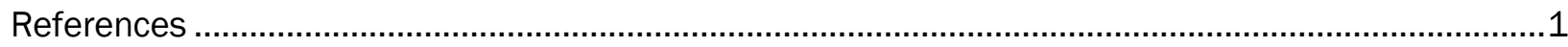

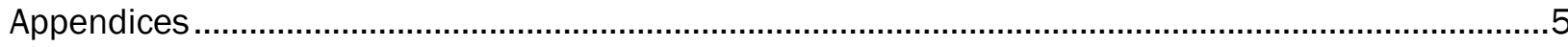

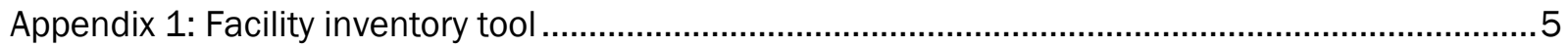

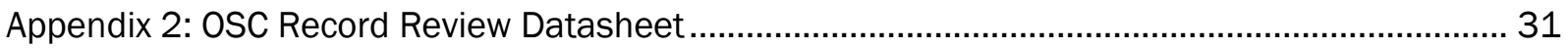

Appendix 3: Guide for Key Informant Interviews with Program Managers and Stakeholders......... 41

Appendix 4: In-depth Interview Guide for Survivors ..................................................................... 44 


\section{ABBREVIATIONS AND ACRONYMS}

AIDS

APHIA

ARV

ASAZA

CAR-E

CARE

CLAN

CRADLE

COVAW

DHS

EC

FIDA

GBV

GBVRC

HIV

HVS

$\mathrm{KNH}$

MSF

MTRH

MUHAS

NGO

OSC

PEP

PMR

RPR

SGBV

UNICEF

USAID

VCT

VSU

YWCA

ZNSA
Acquired Immune Deficiency Syndrome

AIDS, Population, and Health Integrated Assistance

Antiretroviral

A Safer Zambia

Center for Assault Recovery, Eldoret

Cooperative for Assistance and Relief Everywhere

Children's Legal Action

Children's Rights Advisory, Documentation and Legal Centre

Coalition on Violence Against Women

Demographic and Health Survey

Emergency Contraceptive

Federation of Women lawyers

Gender-Based Violence

Gender-Based Violence Recovery Centre

Human Immunodeficiency Virus

High Vaginal Swab

Kenyatta National Hospital

Médicins Sans Frontières

Moi Teaching and Referral Hospital

Muhimbili University of Health and Allied Sciences

Non-Governmental Organization

One-Stop Center

Post-Exposure Prophylaxis

Police Medical Report

Rapid Plasma Reagent

Sexual and Gender-Based Violence

United Nations Children's Fund

United States Agency for International Development

Voluntary Counseling and Testing

Victim Support Unit

Young Women's Christian Association

Zimbabwe National Statistics Agency 
While data are very limited on sexual and gender-based violence (SGBV) in Africa, estimates suggest that SGBV is a major health, human rights, and development issue in the region, as it is globally. Approximately half of the women aged 15-49 (48\%) in Zambia have experienced physical violence, and one in five women have experienced sexual violence (Zambia DHS, 2007). In Kenya, 39\% of women aged 15-49 have ever experienced physical violence since the age of 15, and one in five (21\%) reported sexual violence. Given complicated stigma and reporting issues, it is likely that these national Demographic and Health Surveys (DHS) underestimate the true prevalence and incidence of violence.

Children are not immune to this epidemic. A global school-based survey found that 31\% of girls and $30 \%$ of boys aged 13-15 in Zambia had been forced to have sex (Brown et al., 2009). Results of the study based on responses from males and females aged 18 to 24 indicate that lifetime exposure to childhood violence is exceedingly and unacceptably high in Kenya. Nearly one in three females and one in five males experience at least one episode of sexual violence before reaching age 18 - an experience that can shape their futures in terms of their attitudes towards violence, their adoption of risky behaviors and their emotional health. The figures for physical violence were even more startling, with two in three females and three in four males suffering at least one episode of physical violence. This was defined as slapping, pushing, punching, kicking, whipping, or being beaten with an object (UNICEF et al., 2012).

An increasingly popular strategy for addressing SGBV is through the establishment of 'one-stop centers' (OSCs), which provide integrated, multi-disciplinary services in a single physical location. The basic services of the OSC model in low resource settings in East and Southern Africa comprise health care (including psychosocial support), police and justice sector responses, and ongoing social support (Population Council, 2008; Keesbury \& Askew, 2010). These are often provided within the context of a health facility due to the highly medicalized nature of the initial response services. Although a number of variations exist, at the core of this approach is a system of integrated medicolegal and counseling services. This system can either be physically co-located or can consist of a referral network that links the sectors.

The goals of this assessment were two-fold: First, to assess the effectiveness of different OSC models in terms of health and legal outcomes for survivors, and the cost-effectiveness of these models; and second, to identify lessons learned in OSC implementation with recommendations for both start-up and scale-up. The assessment was conducted in three sites in Zambia and two in Kenya using a comparative case study approach to address the objectives. Three distinct OSC models were examined to determine the core strengths and weaknesses of each. Each OSC was considered as a "case" and multiple data sources were triangulated to assess their individual effectiveness, as well as the comparative effectiveness across sites. Fieldwork took place in Zambia from July-August 2011 and in Kenya from September-December 2011. Data were collected through: 
facility inventories (including cost data); client record reviews; court transcript reviews; and key informant interviews with survivors and local stakeholders. The central findings were as follows:

Three types of OSC models are found in Kenya and Zambia. Kenya and Zambia are among the countries at the forefront of responding to SGBV in Africa through the establishment of OSCs. The assessment found that three OSC models have been implemented in the two countries. The first type is the health facility-based OSC, "owned" by a hospital, implemented by the health facility itself, and working directly with donors to establish and manage OSC functions that are integrated into the health facility's routine activities. The second type is the health facility-based OSC, "owned" by a non-governmental organization (NGO), in which NGOs establish separate centers within existing health facilities to provide "wrap-around" services that strengthen and expand existing clinical services provided by the health facility. This is a common model across African countries. The third type is the stand-alone, NGO-“owned" OSC which provides primarily legal and psychosocial support onsite, while survivors are referred elsewhere for health services.

\section{The health facility-based, hospital-"owned" OSC is best-suited for achieving the broadest} range of health and legal outcomes for survivors. The assessment found that while the health facility-based OSCs "owned" by hospitals offered healthcare services to survivors, the NGO"owned" OSC models did not offer healthcare services to SGBV survivors at their facilities (apart from psychosocial support), but relied on their referral systems. The NGO-owned OSCs did not have the adequate infrastructure, supplies, equipment and, relevant staff to offer clinical management of rape (or other kinds of violence) to survivors, whereas the hospital-owned OSCs did, enabling them to offer essential, clinical services to survivors.

\section{SGBV survivors perceived medical services provided by OSCs as effectively meeting their}

health needs. Acceptability of the medical services provided by health facility-based, hospital“owned" OSCs was high as they addressed survivors' need for privacy and confidentiality while seeking care. All survivors and caregivers who sought services in hospital-"owned" OSCs were satisfied with providers' engagement with them, the type of questions asked, and the empathy shown by providers. The medical care offered was also perceived by survivors and their caregivers as enhancing legal outcomes. Survivors were particularly satisfied with the fact that the services were largely free.

\section{Integration of medico-legal services and police services enhances legal outcomes for}

survivors. The justice and legal components of OSCs remain key in ensuring that the survivors that want to take legal action are able to do so. The findings show that despite many SGBV cases being handled by the OSCs, few are processed through the criminal justice system. Linking medical services with legal/police services in one physical entity would provide an enabling environment for meeting the medical care and legal needs of survivors. A health facility-based, hospital-"owned" OSC emerged as the model in this study with the best legal outcomes for survivors. This may be attributed to the certain medico-legal linkages which facilitated legal processes. 
Despite the establishment of OSCS, the prosecution and conviction of perpetrators remain a major challenge. Perpetrator prosecution and conviction require the cooperation of the police and survivors, but the assessment demonstrates that survivors face challenges in reporting cases to police stations, accessing legal services and representation in court. SGBV stakeholders in Zambia and Kenya reported that both survivors and police played a role in the delay of legal processes. Survivors who make a police report are expected to cooperate and assist the police during investigations, and to be willing to pursue the case up to its conclusion. Although in Kenya there have been efforts to involve the police through SGBV training and the establishment of Gender Desks in police stations, survivors and stakeholders (including donor representatives who fund the OSCs, program managers and staff from each OSC, and external partners who work closely with the OSCs) felt that the effectiveness of these efforts is still limited.

\section{Key stakeholders in Kenya and Zambia consider the existing OSCs as inadequate in} addressing the needs of SGBV survivors holistically. None of the OSC models assessed was considered by key stakeholders as adequately meeting the needs of SGBV survivors because they did not offer the complete range of medico-legal and psychosocial services under one roof. Although the hospital-owned OSCs excelled in the provision of clinical and psychosocial services, linkages to the legal and justice system remained weak. Stakeholders argued that without an integrated system, most clients will continue to receive clinical and psychosocial support, but the prosecution and conviction of perpetrators (for survivors that value this outcome) will not be realized. While the NGO-owned OSC models were perceived to have a strong legal component, their medical and referral systems were weak. Stakeholders argued that this hindered the models from achieving the objective of an OSC, which is to match medical, legal and psychosocial support services. It was noted that medical care is not only crucial for survivors' healing process, but also for adducing evidence so as to ensure the prosecution and conviction of perpetrators.

\section{There is no significant difference in the start-up and operational costs between the two}

NGO-"owned" OSC models. The results suggest that it costs between US\$35,719 and US\$46,069 to start up an NGO-owned one-stop center as a stand-alone structure, or as part of a health facility. Start-up costs for the hospital-owned OSC model could not be derived because services are integrated within the hospital set-up. In terms of operational costs, there is also no significant difference between the two NGO-owned OSC models (stand-alone and health facility-based), while there is a slight difference between them and the health facility-based, hospital-owned models. It costs between US $\$ 24.70$ and US $\$ 26.10$ per client per year for staff salaries to run an NGO-owned OSC (whether stand-alone or health facility-based); and about US $\$ 31.90$ per client per year for staff salaries to run a hospital-owned, health facility-based OSC.

Lessons learned in OSC implementation include: The health facility-based, hospital-owned OSC model is best-suited for achieving the broadest range of health and legal outcomes; a multidisciplinary team of staff ensures the best health outcomes for survivors; psychosocial support 
services should include support groups for SGBV survivors; signing of the police medical report forms should take place within OSCs; collection and storage of forensic evidence by OSCs is critical; provision of legal services, including legal advice and court preparation, enhances legal outcomes; integration of medico-legal, psychosocial support and police services in one physical (but not 'standalone') location should be promoted; the needs of child survivors of SGBV have to be better integrated into all levels of OSC services.

Recommendations for introduction and scale-up of OSCs include: Establishment of OSCs offering a multi-disciplinary staff and comprehensive SGBV services including clinical, psychosocial (comprising child-friendly, child protective services for children), and legal to meet the needs of survivors in one physical location; funding for OSCs should be adequate, sustainable, and part of government budgets; the cost of starting up OSCs could be leveraged by health facilities for OSCs that are established within these contexts; advocacy to operationalize the legal right of trained nurses to conduct forensic examinations and to sign the medical forms necessary for entering the results into evidence; advocacy for the health facility-based, hospital-owned OSCs as the most ideal model for ensuring survivor-centered services, and for promoting sustainability. 


\section{INTRODUCTION}

While data on the existence of Sexual and Gender-Based Violence (SGBV) in Africa are only emerging ${ }^{\text {ii }}$, existing estimates suggest that it is a major health, human rights, and development issue in the region, as it is globally. Approximately half the women aged 15-19 (48\%) in Zambia have experienced physical violence, and one in five women have experienced sexual violence (Zambia DHS, 2007). In Kenya, 39\% of women aged 15-49 have ever experienced physical violence since the age of 15 , and one in five $(21 \%)$ reported sexual violence, which referred to ever being forced to have sexual intercourse or perform any other sexual acts against one's will (KDHS 2008-09).

Large scale surveys in Swaziland, Tanzania, Zimbabwe, and Kenya indicate that levels of violence against children are high, with generally 1 in 3 girls and 1 in 5 boys suffering some form of sexual violence before age 18 (Reza et al., 2009; UNICEF, CDC, \& MUHAS, 2011; ZNSA, 2012). Levels of physical violence tend to be even higher. Given complicated stigma and reporting issues, it is likely that these national household surveys underestimate true prevalence and incidence of violence.

\section{The 'one-stop center' approach to SGBV response}

While the full extent of SGBV may not be known in many countries, rates of violence are high enough to warrant a meaningful response from governments and civil society. To increase access to care and support, many countries in the region have invested in improving the quality and quantity of services offered in public institutions. An increasingly popular strategy for doing this has been through the establishment of 'one-stop centers' (OSCs), which provide integrated, multi-disciplinary services in a single physical location - generally, a medical facility.

The basic services forming the core of the OSC model ${ }^{\mathrm{iii}}$ implemented in East and Southern Africa (Keesbury \& Askew, 2010), and summarized in Table 1, encompass health care, police and justice sector responses, and on-going social support. These are often provided within the context of a health care institution, due to the highly medicalized nature of the initial, emergency response services. Although a number of variations exist, at the core of this approach is a system of integrated medico-legal and counseling services. This system can be physically co-located and/or can consist of a referral network that ensures access to other essential services. As stakeholders in Kenya noted, this "concept refers more to a system than to a single physical entity in Kenya: health and psychological needs are addressed under one roof - judicial and legal services have to be incorporated. ${ }^{\text {,iv }}$ All services are intended to meet the dual objectives of improving care and support for the survivor and increasing prosecution of the perpetrator where this endeavor aligns with the wishes of the survivor. Therefore, OSCs offer the opportunity to assess services offered to survivors from initial contact at the Centers to the medium- and long-term health and legal outcomes. 
Table 1: Key components of a multi-sectoral response provided at an OSC

\begin{tabular}{|l|l|}
\hline Sector & Key components of response provided at an OSC \\
\hline \multirow{5}{*}{ Clinical } & Comprehensive medical examination and treatment \\
Laboratory tests
\end{tabular}

Several studies have documented the relative effectiveness of OSCs in North American and European settings in providing integrated health care, forensic services, counseling, and social services for both children and adults (Newman et al., 2005; Snell, 2003). However, there is limited evidence on the acceptability, effectiveness or cost of this approach as currently applied in the African context (Chomba et al., 2010). In low-resource settings in Africa, many countries have opted to overcome challenges posed by material and human constraints by establishing stand-alone OSCs. While often housed within a public hospital or health center, OSCs are often administered and funded separately and are typically highly dependent on external support for sustainability. Programs report that OSCs have increased access to services in the areas where they operate, but limited data are available to confirm this or guide scale-up efforts (ibid.).

As the OSC approach becomes more widely adapted across Africa, this is an opportune moment to expand the evidence base on the model in the African context. This study is one of the first in Africa to assess the effectiveness of OSCs on health and legal outcomes of survivors, building on previous research from South Africa (Vetten et al., 2008). To our knowledge, it is the only study to date in the region that compares different OSC models using medical and legal data sources from the survivors' first contact with the centers all the way through to court outcomes.

Findings from this study offer the first form of systematic evidence on the effectiveness of OSCs (using a methodology pioneered by the Medical Research Council and Center for the Study of Violence in South Africa (ibid.)), which can guide national-level policymakers and program managers in introducing or adapting the OSC model in their countries. 


\section{STUDY OBJECTIVES}

The overall objectives of the study were to:

- Assess the effectiveness of different OSC models on health and legal outcomes of adult and child survivors, as well as the cost-effectiveness of these models

- Identify lessons learned in OSC implementation and make recommendations for introduction and scale-up.

The specific objectives were to:

- Determine effectiveness of OSC models in addressing the short and long-term health needs of adult and child survivors

- Determine effectiveness of OSC models in impacting legal outcomes of adult and child survivors

- Determine the cost per client of delivering services in each OSC model

- Identify components of each model that are most effective and potentially replicable at the national or regional level.

'Legal outcomes' take several forms. This study took place in a context in which the concept of OSCs is still relatively new, and in which legislation around SGBV is also recent (e.g., Kenya's 2006 Sexual Offences Act). A key interest of this study was, thus, to examine legal action in OSC settings. 'Legal outcomes' is therefore defined here as the prosecution and conviction of perpetrators. 


\section{METHODOLOGY}

\section{Overview of Study design}

This study was conducted in Zambia and Kenya using a comparative case study approach to address the overall and specific objectives. These countries were chosen because they are among the African countries at the forefront of adopting of different approaches to the OSC model as part of SGBV service delivery. Fieldwork took place in Zambia from July-August 2011, and in Kenya from September- December 2011.

The study examined three distinct models to determine the core strengths and weaknesses of each. These were treated as individual cases studies and compared across a set of core indicators (Baxter and Jack, 2008) to respond to the issues noted above. The case study methodology is particularly suited for health services research, program evaluation and intervention development. In this study, each OSC was considered as a "case" and we integrated and triangulated multiple data sources (qualitative and quantitative) to assess the individual effectiveness of each OSC and comparative effectiveness across sites.

Specifically, this study consisted of four components: facility inventories, including cost data; OSC client record reviews; court transcript reviews; and key informant interviews (KIIs) with survivors, caregivers of child survivors, and local stakeholders. The facility inventories and KIIs were the main primary data sources, while the rest were secondary data sources in the form of existing records. The facility inventories and KIIs helped to answer questions of OSC acceptability, effectiveness, and cost, and how this varied between survivors above and below the age of 18 . Analysis of court transcripts and stakeholder interviews helped to answer the question of whether OSC services helped to improve legal outcomes, defined here as prosecutions and convictions. Finally, we conducted a cross-country comparison of relative effectiveness of the OSC models in Kenya and Zambia based on the results obtained. The data show the relative effectiveness of the OSC models and the comparative strengths of the different models as implemented across the countries.

\section{Study sites}

To inform site selection, a mapping of OSCs outlining the services provided and institutional characteristics of each site was undertaken in each country. All sites offered the comprehensive services outlined in Table 1, either through direct service provision or referrals. Three broad categories of OSCs emerged from this mapping. Within health facilities, where most OSCs are based, the centers tend to be "owned" either by NGOs or the facility itself; stand-alone NGO-run centers were also present in both countries. The NGO "owned" model is common across Africa, with externally-funded NGOs establishing separate centers within existing health facilities and providing wrap-around services that strengthen and expand existing clinical services provided by the hospital. The health facility "owned" models in this study are driven the health facility itself, which 
works directly with donors to establish and manage OSC functions that are more integrated into the health facility's routine activities. The stand-alone approach investigated in this study provides primarily legal and psychosocial support onsite, while survivors are referred elsewhere for health services.

Following consultations with partners, review of available data, and site inspections, two OSCs in Kenya and three OSCs in Zambia were chosen for inclusion in this study. Sites were selected based on the following criteria:

- Currently operational, and had been active for at least one year to allow for record reviews.

- Offered medical, legal and psychosocial care services in same location, or actively referred if all services are not offered on site.

- Granted the research team access to their program data and staff.

The five OSCs included in this study represented different approaches to the OSC model. The sites in Zambia consisted of two types of health facility-based OSCs - one that is "owned" by an NGO and one that is "owned" by the health facility itself - in addition to a stand-alone, NGO "owned" site. The sites in Kenya were both health facility-based, hospital "owned” OSC models.

The nature and content of each OSC model differs substantially. To the extent possible, however, this study compared the performance of different types of health facility-based OSCs to stand-alone centers, looking both within and across countries. The indicators examined to assess performance included: clinical and psychosocial support provided; police/legal services offered; legal outcomes of cases handled; and cost per client of delivering services.

Table 2 provides a summary of specific information on all five OSCs between December 2010 and December 2011. 
Table 2: Zambia and Kenya OSC models included in study

\begin{tabular}{|c|c|c|c|c|c|}
\hline \multirow{2}{*}{ Model } & \multirow{2}{*}{ Facility } & \multirow{2}{*}{$\begin{array}{l}24 \text { hour } \\
\text { services? }\end{array}$} & \multicolumn{3}{|l|}{ Services offered } \\
\hline & & & Clinical care & Police/Legal & Psychosocial \\
\hline \multicolumn{6}{|l|}{ Zambia } \\
\hline $\begin{array}{l}\text { Health facility- } \\
\text { based OSC } \\
\text { "owned" by } \\
\text { NGO }\end{array}$ & Mazabuka & No & $\begin{array}{l}\text { Referred within } \\
\text { hospitalv }\end{array}$ & $\begin{array}{l}\text { On-site paralegal } \\
\text { and police Victim } \\
\text { Support Unit (VSU) } \\
\text { officer }\end{array}$ & $\begin{array}{l}\text { Full-time counselors on- } \\
\text { site } \\
\text { Survivors' groups } \\
\text { Referred to safe house }\end{array}$ \\
\hline $\begin{array}{l}\text { Health facility- } \\
\text { based OSC } \\
\text { “owned" by } \\
\text { hospital }\end{array}$ & Mansa & No & $\begin{array}{l}\text { Nurse and clinical } \\
\text { officers on-site, } \\
\text { work with hospital } \\
\text { staff (doctors) }\end{array}$ & $\begin{array}{l}\text { Referred within } \\
\text { Mansa Hospital to } \\
\text { VSU officer }\end{array}$ & $\begin{array}{l}\text { Full-time counselor and } \\
\text { part-time counselors on- } \\
\text { site }\end{array}$ \\
\hline $\begin{array}{l}\text { Stand-alone, } \\
\text { NGO-“owned” } \\
\text { OSC }\end{array}$ & $\begin{array}{l}\text { YWCA } \\
\text { Burma }\end{array}$ & Yes & $\begin{array}{l}\text { Refer to University } \\
\text { Teaching } \\
\text { Hospitalvi }\end{array}$ & $\begin{array}{l}\text { On-site VSU officer } \\
\text { and paralegal }\end{array}$ & $\begin{array}{l}\text { Full-time counselors on- } \\
\text { site } \\
\text { Survivors' groups } \\
\text { Referred to safe house }\end{array}$ \\
\hline \multicolumn{6}{|l|}{ Kenya } \\
\hline $\begin{array}{l}\text { Health facility- } \\
\text { based OSC } \\
\text { "owned" by } \\
\text { hospital }\end{array}$ & $\begin{array}{l}\text { Kenyatta } \\
\text { National } \\
\text { Hospital }\end{array}$ & No & $\begin{array}{l}\text { Doctors } \\
\text { (psychiatrists)and } \\
\text { nurses on site }\end{array}$ & $\begin{array}{l}\text { Referred to legal } \\
\text { NGOs }\end{array}$ & $\begin{array}{l}\text { Full-time nurse } \\
\text { counselors, } \\
\text { psychologists, and } \\
\text { social worker on site } \\
\text { Survivors' groups } \\
\text { Referred to safe houses }\end{array}$ \\
\hline $\begin{array}{l}\text { Health facility- } \\
\text { based OSC } \\
\text { “owned" by } \\
\text { hospital }\end{array}$ & $\begin{array}{l}\text { Moi } \\
\text { Teaching } \\
\text { and } \\
\text { Referral } \\
\text { Hospital }\end{array}$ & Yes & $\begin{array}{l}\text { Doctors and } \\
\text { nurses on site }\end{array}$ & $\begin{array}{l}\text { Referred to legal } \\
\text { NGO }\end{array}$ & $\begin{array}{l}\text { Full-time nurse } \\
\text { counselors, social } \\
\text { worker on site } \\
\text { Survivors' groups }\end{array}$ \\
\hline
\end{tabular}

A more detailed description of the selected one-stop centers follows.

\section{Zambia Sites}

\section{Mazabuka OSC}

Mazabuka is a health facility-based OSC "owned" by an NGO. Established in 2008, it was managed by World Vision under the ASAZA project. ${ }^{\text {vii }}$ The OSC is situated within the premises of Monze District Hospital and is a stand-alone site situated approximately 150 meters from the main hospital building. It is staffed with a paralegal officer, counselors, and a police officer within the Victim Support Unit (VSU). Survivors are referred for clinical care to a different department in the facility. The hours of operation are 8 am to 5 pm on weekdays, with staff counselors being on call outside these hours. All members of staff in the OSC are funded by the ASAZA project.

\section{Mansa OSC}

The Mansa OSC was established in 2009 and differs from other models in Zambia because it is managed by the Mansa General Hospital, while external partners (primarily UNICEF) provide external support, such as office furniture, toys for children, and medical equipment. The OSC is located within the hospital and provides health and counseling services on-site. For police/legal 
services, clients are referred to an off-site VSU officer. MoH staff at the hospital are primarily relied upon to run this OSC, while UNICEF and other partners give technical assistance, such as training. The hours of operation are 8 am to $5 \mathrm{pm}$ from Monday to Friday. Outside of these hours, clients are referred to the Outpatient or Gynecology departments.

\section{YWCA Burma}

YWCA Burma is a stand-alone, NGO-owned OSC. Established in 2006, it is based at the YWCA headquarters. It offers police, legal and counseling services on-site, and survivors are referred to the University Teaching Hospital, located about 800 meters away, for clinical services. The Center provides 24-hour services and all staff are paid under the ASAZA project.

\section{Kenya Sites}

\section{Gender-Based Violence Recovery Centre (GBVRC), Kenyatta National Hospital}

A health facility-based OSC “owned” by a national-level referral hospital, the GBVRC is managed by Kenyatta National Hospital (KNH). It was established in 2006 and re-launched in 2008 with support from Liverpool VCT, Care \& Treatment, the CRADLE, Coalition on Violence against Women (COVAW), American Women's Association, and other partners. The GBVRC is situated within KNH's Patient Support Centre (re-named the 'Mental Health Department' in 2012). Though the clinic is open Monday to Friday from $8.00 \mathrm{am}$ to $5.00 \mathrm{pm}$, after $5.00 \mathrm{pm}$, a trained nurse is stationed in the Outpatient Department at the hospital's Emergency and Casualty Department for night and weekend services. The clinic, being located in the Mental Health Department, is staffed with psychiatrists, nurse counselors, psychologists, and a social worker. Survivors receive trauma counseling and continued psychosocial support through SGBV support groups, and are referred within KNH for medical care. They are also referred outside KNH to various partners for legal aid, social assistance, and police intervention. The GBVRC was supported by the USAID-funded AIDS, Population, and Health Integrated Assistance (APHIA) II project in 2010, and from October 2011 to date, has been supported by APHIA-Plus, the successor of the APHIA II project. Personnel costs are covered by the government, although one psychologist is currently being supported by an NGO (Pathfinder International).

\section{Moi Teaching and Referral Hospital}

The OSC at Moi Teaching and Referral Hospital (MTRH) is health facility-based OSC “owned” by this provincial-level hospital and located within MTRH's Accident and Emergency Out-Patient Department. Known as the Center for Assault Recovery, Eldoret (CAR-E), the OSC at MTRH was established in May 2007. It is managed by the hospital and supported by external partners, including Indiana University and the German Development Corporation. It offers medical and psychosocial services to SGBV survivors and provides off-site referrals to a legal aid center. It is staffed with medical officers, nurse counselors, and a social worker. A total of fifty hospital staff in other 
departments have been trained in SGBV. The clinic is open 24 hours, seven days a week. Staff are paid by the hospital.

\section{Ethical Considerations}

The bulk of this research did not involve human subjects, and the risk of violating confidentiality was minimal due to the coding system that was employed. Survivor interviews posed the greatest potential risk for participants, and extensive measures for mitigating that risk were put in place. The anonymity of participants was protected through the coding system, where each record was assigned a unique identifier. All respondents gave informed consent prior to the interview. No identifiers were collected in the record review. Each data review sheet was given a unique record code to ensure the anonymity of the survivor.

A team of research assistants, each with wide-ranging experience in collecting data under sexual and reproductive health-related research projects (and several of whom were SGBV survivors themselves) was trained over a four-day period. The training session focused on: sensitizing trainees on the issue of SGBV, ethics, informed consent, the project goals, the content and rationale behind each of the study tools and the informed consent forms, and data collection techniques.

This study was reviewed and approved by the University of Zambia Research Ethics Committee and the Kenyatta National Hospital/University of Nairobi Ethics and Research Committee. It was determined as exempt from full ethical review by the Population Council Institutional Review Board (based in New York) as stringent ethical procedures had been developed and therefore the research did not pose more than minimal risks to human subjects.

\section{Data collection methods}

The study collected both qualitative and quantitative data ${ }^{\text {vii }}$ with respondents at facility and national levels in order to generate multi-level perspectives and understandings. Primary data were collected through facility inventories and key-informant interviews to understand service provision, infrastructure of the different OSCs, as well as their acceptability, cost, and effect on health outcomes. Secondary data were collected through review of records, including OSC client medical and court records. Methods and types of data collected are described below.

\section{Facility Inventory}

A facility inventory was conducted in each of the OSCs to document existing infrastructure and human resource capacity, service availability, and the referral system and guidelines. The facility inventory was also used to collect data on cost of services delivered at the OSCs in order to determine the cost-effectiveness of different models. The data collected included start-up and recurrent costs of providing services, identification of specific cost ratios, and incremental cost of expanding services to the national population. 


\section{Record reviews}

Information from on-site OSC records and court transcripts was collected, including OSC client management files, medical, police and paralegal records. Trained data collectors accessed the records for each client and recorded key information from each case onto a standardized datasheet. These standardized datasheets captured client data across the entire treatment and judicial process, including clinical services provided, medico-legal examinations and documentation, counseling and referrals, follow-up care sought, legal actions and court outcomes. This information was compared against service delivery indicators to measure performance of the different OSC models.

\section{Key informant interviews}

Quantitative data (i.e., records review and facility inventory) were triangulated with qualitative data collected through a series of interviews on service establishment and quality with key informants, and through in-depth interviews with survivors who had received services through each OSC model.

A total of 15-20 key informants were interviewed in each country and included key stakeholders such as donor representatives who fund the OSCs, the program managers and staff from each OSC, and external partners who work closely with the OSCs. Interviews focused on the preconditions and requirements for establishing OSCs; challenges associated with set-up and successful strategies for overcoming challenges; overall assessment of OSC functionality (by site); perceived quality of clinical care (by site); barriers to quality care; perceived quality of police/legal services (by site); barriers to prosecution; perceived quality of social services (by site); barriers to social support; strengths and weakness of the OSC model; and its potential for sustainability and replicability at different administrative levels. Interviews were also conducted with SGBV survivors and with caregivers of child survivors to assess the quality of care provided to them at the various OSC models. Five interviews were conducted at each site - a total of 15 in Zambia and 10 in Kenya. Survivors were recruited through existing survivor support groups or counseling sessions that are organized through the OSCs to provide on-going psychosocial support. Interviews were tape recorded and transcribed for analysis.

\section{Data Processing and Analysis}

All data were securely stored in the Population Council's Lusaka and Nairobi offices, and all coding lists stored separately from the data to ensure that individual cases could not be identified. Given the relatively small number of facilities included in the study, facility inventory data were analyzed manually.

Data from the record reviews were entered using EpiData, a quantitative software with built-in and programmable checks that ensure data quality. Data were double-entered and duplicate files 
compared for consistency and transported to SPSS for analysis. The taped key informant and survivor interviews were transcribed and read through to identify themes configured along the lines of topical inquiry (see Appendix for field guides). The text was sorted by the codes (sub-themes) generated from the transcripts and analyzed for similarities and differences.

The accounting approach (also referred to as the 'ingredients approach') to the estimation of the costs of setting up and running a one-stop center was employed to arrive at the cost per client of delivering services in each OSC model. The accounting approach makes use of the quantities and prices of an individual SGBV case and sums it over the expected number of cases in a given setting. This approach is the most commonly-used in empirical estimations due to its appeal: it allows a better understanding of various cost components (Jehle \& Reny, 2001), and in the event of scale-up, program estimates in budgets and resource allocations are easier to comprehend. Another possible approach to estimating the cost of OSCs would be the econometric approach. The latter would involve estimating an econometric model either based on individual cases observed at one OSC or within several OSC settings. This approach was considered inappropriate because of the intended purpose of the cost estimates in this study, which was to estimate the unit cost of attending to SGBV cases. $^{\text {ix }}$

\section{Limitations}

Although this study examined the health and legal needs and outcomes of both adult and child survivors, children's voices are absent from this report. For ethical reasons, only survivor interviewees above the age of 18 were recruited to participate in the study. To gain some sense of outcomes where children are concerned, caregivers of child survivors were interviewed rather than

the children themselves. It is possible that children's actual perspectives on SGBV services received at the OSCs vary from the perspectives provided by their caregivers. 


\section{FINDINGS AND DISCUSSION}

\section{An overview of the study's OSC models}

\section{OSCs in Kenya}

In the recent past, considerable effort has been made by various stakeholders to address SGBV in Kenya. According to Kenya's Division of Reproductive Health, Ministry of Public Health and Sanitation, integrated treatment and care must include the community, legal and justice system, and medical services. ${ }^{\mathrm{x}}$ Most facilities, both government and NGO, provide one or two of the core services on-site and then refer survivors for other support services. The bulk of health facilities were found to offer medical and psychosocial support, and then to refer survivors to police or legal aid support from NGOs. NGO facilities, on the other hand, tended to offer legal aid and psychosocial support, and then refer survivors for medical services and shelter.

Kenya's first OSC, offering free medical and psychosocial services, was established in 2001 by Nairobi Women's Hospital, a private for-profit health facility. With the support of various stakeholders, over 20 more OSCs have been established since, primarily in government health facilities, across the country, including KNH (Nairobi), and MTRH (Eldoret), with the majority established in the midst of Kenya's 2007-08 post-election violence experience. Five stand-alone NGO and legal service providers identified included the Médicins Sans Frontières (MSF)-France Juja Road Center and the MSF-Belgium Kibera Center, The Cradle, Children's Legal Action (CLAN), and the Federation of Women Lawyers (FIDA). Liverpool VCT, Care and Treatment (LVCT) also offers limited OSC services.

The mapping exercise revealed that the three most common forms of gender-based violence handled at these OSCs are sexual, physical and intimate partner violence ${ }^{\mathrm{xi}}$. Sexual violence, as documented within these OSCs, includes rape, 'sodomy'xii and 'defilement. 'xiii Women and children (primarily girls, but also boys) are the primary service seekers in these areas.

\section{OSCs in Zambia}

From 2005 to 2007, CARE Zambia and its partners implemented a pilot project geared toward developing a successful model for one-stop centers in Zambia. The first two pilot one-stop centers (dubbed 'Coordinated Response Centers' (CRCs) in Zambia) were opened in Lusaka and Chipata by CARE Zambia and its partners to ensure direct service delivery to SGBV survivors comprising medical help (including the collection and preservation of criminal evidence), legal support (including reporting the crime to the police and legal advice where needed) and psychological support (including counseling and linking to survivor support groups and, if needed, safe houses or shelters). Both sites were stand-alone sites (not located in a health facility) and driven by NGOs, but with a referral system to the nearby health facility for secondary medical management.

In the meantime, the first actual OSC in Zambia was established in 2006 in the pediatric unit of Lusaka's University Teaching Hospital (Chomba et al., 2010). CARE Zambia's pilot project was later 
expanded, thorough the 'A Safer Zambia' (ASAZA) project from September 2007 to December 2011 (USAID and CARE, 2011). Today, there are a total of eleven such centers located across the country's urban and peri-urban areas (Chomba et al, 2010).

Following the successes scored under the pilot project, eight OSCs were established in seven districts under the ASAZA project, involving a number of SGBV preventive and restorative initiatives. Preventive initiatives include informational, educational and behavior-change communications, while the restorative initiatives involve the provision of direct support to survivors, including medical, psychosocial and legal services. At each ASAZA Coordinated Response Center, there is a team of counselors, paralegal and VSU officers, and clinical staff (mainly nurses), coordinated by a facility manager.

Apart from the two pilot sites that continue to operate as stand-alone centers, all the scale-up sites are health facility-based (3 provincial hospitals and 3 health centres). In 2008, UNICEF also started supporting the implementation of an OSC model at Mansa General Hospital. This OSC relies much more on $\mathrm{MoH}$ staff at the hospital than project staff (with UNICEF and other partners providing supplies and technical assistance) compared to other OSC models in the country.

It has been argued that the stand-alone, NGO-owned model is less traumatic to survivors as it is in a private setting and more flexible in terms of use of space by accommodating emergency transit for SGBV survivors who do not require referral to a safe house (Munalula \& Kanyengo, 2011). On the other hand, medical staff are not available on a 24 hour basis, and, in most cases, clients need to be driven to a health facility. As a result, survivors' access to critical health services (e.g., EC, PEP) within the first 72 hours is hindered, and evidence may also be lost in the process of evacuating a survivor to a health facility. Among the identified advantages of the health facility-based model are: guaranteed medical personnel 24 hours a day; easier access to examination and treatment of SGBV cases, since the examination room is within the building; easy access to PEP, EC and ARVs; and stigma mitigation, given that situating OSCs within a health facility (vis-à-vis having OSCs stand alone) offers more privacy and lessens the likelihood of a survivor being identified and "branded," thus hampering access to services. However, there have been concerns about SGBV survivors shunning hospital settings due to stigma-related fears (Munalula \& Kanyengo, 2011; Undie et al., 2012). In addition, concerns have been raised about the limited space available in some of these contexts (Munalula \& Kanyengo, 2011), which poses challenges for confidentiality and privacy of consultations and examinations.

\section{Effectiveness of OSC models in addressing the short and long-term health needs of survivors}

This study assessed the effectiveness of three OSC models in addressing health needs of survivors, with a focus on availability of services, accessibility, staff, infrastructure, essential equipment and supplies, referral system and guidelines, and follow-up care. Table 3 (below) shows the availability of SGBV-related clinical services reported in the three OSC models studied. 


\section{Clinical Services}

The results show that the stand-alone, NGO-owned OSC model and the health facility-based OSC owned by an NGO did not offer healthcare services to survivors reporting SGBV to their Centers (including basic clinical services, such as HIV testing, PEP, and emergency contraception), but referred survivors to external sources of health care. On the other hand, all three health facilitybased, hospital-owned OSCs were found to offer healthcare services, although only MTRH in Kenya offered the complete range of essential clinical services.

Table 3: Clinical Services and psychosocial support provided at the various One-Stop Centers

\begin{tabular}{|c|c|c|c|c|c|}
\hline & Zambia & Zambia & Zambia & Kenya & Kenya \\
\hline Services & $\begin{array}{l}\text { Burma } \\
\text { NGO-based } \\
\text { stand alone }\end{array}$ & $\begin{array}{l}\text { Mazabuka } \\
\text { NGO “owned" }\end{array}$ & $\begin{array}{l}\text { Mansa } \\
\text { Hospital } \\
\text { "owned" }\end{array}$ & $\begin{array}{l}\text { KNH } \\
\text { Hospital } \\
\text { "owned" }\end{array}$ & $\begin{array}{l}\text { MTRH } \\
\text { Hospital } \\
\text { "owned" }\end{array}$ \\
\hline \multicolumn{6}{|l|}{ A: Clinical services } \\
\hline HIV counselling and testing & No & HIV counselling only & Yes & Yes & Yes \\
\hline Provision of PEP (adult) & No & No & Yes & No & Yes \\
\hline Provision of PEP (paediatric) & No & No & Yes & No & Yes \\
\hline Pregnancy testing & No & No & Yes & No & Yes \\
\hline Provision of EC & No & No & No & Yes & Yes \\
\hline Treatment of physical injuries & No & No & No & No & Yes \\
\hline Forensic examination (adult) & No & No & No & No & Yes \\
\hline Forensic examination (paediatric) & No & No & Yes & No & Yes \\
\hline $\begin{array}{l}\text { Signing of the police medical } \\
\text { report form }\end{array}$ & No & No & No & No & Yes \\
\hline \multicolumn{6}{|l|}{ B: Psychosocial support } \\
\hline Trauma counselling provided & Yes & Yes & Yes & Yes & Yes \\
\hline Referred to off-site safe house & Yes & Yes & No & Yes & No \\
\hline Survivor groups & Yes & Yes & No & Yes & Yes \\
\hline
\end{tabular}

The stand-alone, NGO-owned model and the health facility-based, NGO-owned model (both located in Zambia) were not set up with the adequate infrastructure and relevant staff to offer SGBV related health care services to survivors. The facility inventory data further revealed that these two OSC models were lacking in essential equipment and supplies required for a range of SGBV related clinical services. For instance, the OSCs did not have EC, analgesia, HIV rapid test kits, and PEP drugs.

The health facility-based, hospital-owned OSC model facilities were comparatively better off in terms of infrastructure, relevant clinical staff, and essential equipment and supplies, which enabled them to offer essential SGBV-related clinical services to survivors within their premises, or at least within the wider hospital setting. At the time of the assessment, KNH OSC did have medical doctors (psychiatrists) stationed at the center, but it did not have medical doctors specifically for clinical services on-site. For clinical services, adult clients were seen at the Accident and Emergency 
Department's gynecology room, while children were seen at the pediatric ward. Despite nurses being trained in forensic collection of evidence for SGBV, forensic evidence is no longer being collected at $\mathrm{KNH}$ due to weak linkages between the hospital and the police. Previously, samples taken from survivors by KNH nurses were not picked up by the police for forwarding to the forensic laboratory or to the Government Chemist. The samples thus remained in storage, leading to a shortage in storage space at the hospital.

At the MTRH, the OSC exclusively provides SGBV services and is run by two medical doctors, four nurse counselors and a records clerk. Clinical services are offered at the center by the medical doctors, while nurse counselors provide psychosocial support for both adults and children. Services are offered round the clock and there is a doctor and a nurse on call for survivors during the night and on weekends. In the doctors' room, examinations, forensic preservation, ARV prophylaxis and emergency contraception are provided, while counseling and psychosocial support are provided in the counseling room.

A review of records of 394 cases in the health facility-based, hospital-owned OSCs in Kenya confirmed that survivors had received essential clinical services in response to SGBV. These services included pregnancy test (Gravidex), RPR test for syphilis, HVS to detect the presence of sperm, HIV test (Elisa/Determine), and provision of PEP and EC. About 70 percent of the cases reported were related to sexual violence, with defilement accounting for 36 percent of reported cases, and rape, 34 percent. In Zambia, defilement accounted for about five percent of cases while rape accounted for one percent. ${ }^{\text {xiv }}$

Where OSCs do not include health services, as in the case of the NGO-owned OSC models (both stand-alone and health facility-based), there is need for a referral network that links the facility to the health sector and other sectors and services. In this study, we assessed the referral systems and guidelines of the two OSC models that did not incorporate health services in order to find out how the immediate health needs of the survivors were addressed. The findings showed that the two OSCs had written guidelines for the referral of survivors to other services in place. YWCA Burma did have written guidelines/protocols for the clinical management of SGBV as well, while Mazabuka OSC did not. The existing referral systems and guidelines were found to be inadequate to meet survivor needs, however. For instance, in the stand-alone, NGO-owned model, there were written guidelines for referral of survivors to other services, but the guidelines did not include the phone numbers and contact people at each referral point. Neither NGO-owned OSC had special provisions for examining and treating infants and children in their written guidelines or protocols for the clinical management of SGBV, nor did their general guidelines explicitly address procedures for removing a child (or an adult) from an unsafe domestic environment. On the other hand, these issues were addressed by the hospital-owned OSCs (KNH and MTRH), although the written guidelines at MTRH did not explicitly address procedures for removing a child (or an adult) from an unsafe domestic environment. Mansa OSC (also hospital-owned) did not have written guidelines or protocols for the clinical management of SGBV. 
At the time of the study, YWCA Burma, KNH, and MTRH were the only OSCs that had special aids for examining children (e.g., toys, crayons, paper, etc.). Overall, the hospital-owned OSCs were better prepared to meet the needs of children. They were also the only OSCs with a social worker on-site (KNH and MTRH, specifically) to attend to the social services needs of children and adults.

The referral systems of health facility-based, hospital-owned OSCs (specifically, Mansa and $\mathrm{KNH}$ ) in regard to clinical services involved referral to another department within the same hospital.

Overall, the hospital-owned OSCs have the capacity to offer effective health care services which address short and long-term health needs of adult and child survivors. The same capacity is lacking in the NGO-owned models, marked by unavailability of staff, incomplete infrastructure, equipment and supplies.

Among the health facility-based, hospital-owned models, it was found that the MTRH (Kenya) approach (in which the OSC is exclusively for SGBV services, most offered under one roof) offered the most comprehensive health care to survivors, including forensic collection of evidence and signing of police medical report forms. The signing of police medial report forms at the OSC is an important procedure that enhances the chances of positive legal outcomes for survivors that would like to take legal action. Of all the OSCs, MTRH was the only one that handled this procedure.

Nonetheless, the NGO-owned OSC were the only ones that were staffed with paralegals and VSU officers on-site.

\section{Psychosocial support services}

Counseling is an important part of SGBV services in that it reduces the psychological stress experienced by survivors. Approaches to providing this critical service include one-on-one counseling and/or group therapy, and where children are involved, both children and their caregivers can be counseled. The counseling process begins when survivors present themselves to an OSC in order to deal with the immediate trauma of violence. It also prepares them for HIV and pregnancy tests which in turn inform the clinical response.

All the OSC models provided psychosocial support services. Psychosocial support was provided mainly by full-time, paid counselors or nurse counselors across all the models, although $\mathrm{KNH}$ also had full-time psychologists and psychiatrists on staff who equally provided this form of support. This was supported by the survivor interview data and record review data. For instance, the record review data in Kenya showed that 83 percent of the survivors met a counselor on their first visit to the KNH and MTRH OSCs. In Zambia, 96 percent of survivors attending the stand-alone, NGOowned OSC and the health facility-based, NGO-owned OSC model met a counselor on the first visit, while 49 percent met a counselor on their first visit to the health facility-based, hospital-owned OSC. All OSCs in this study, except for Mansa OSC, had support groups for SGBV survivors to meet each other and share experiences. Survivor interview data showed that support groups attendees found these forums useful in their healing process: 
The first meeting, I came to release [the] tension that I had in my heart and I saw other ladies there and they were happy. You choose to be happy and I just told myself, there isn't much I can do about it. I've to choose to be bappy (Survivor, Kenya).

The main challenge to attending support groups was transport costs to the OSCs.

There appears to be no remarkable difference in the way the different OSC models offered psychosocial support services as they all had the infrastructure and capacity to offer the services. Referrals to off-site safe houses were offered at Mazabuka, YWCA Burma, and KNH. Overall, however, a higher proportion of survivors attending the NGO-owned OSCs (as opposed to hospital-owned) met a counselor on their first visit, and the NGO-owned OSCs provided referrals to off-site safe houses, unlike the hospital-based models (except for $\mathrm{KNH}$, which also provided this form of psychosocial support). All OSCs in the study ran survivor support groups, apart from Mansa.

\section{Acceptability and effectiveness of the different OSC models in addressing health outcomes}

As psychosocial support is a critical component of health in general and impossible to separate from physical health, questions around this issue formed part of survivor interviews. Psychosocial support was perceived to be highly effective by all survivors and caregivers interviewed. They reported going back to OSCs for follow-ups, supportive counseling, and support group meetings, where these were available.

Survivors were also asked about their perceptions of the medical care that they received at the different OSCs. Questions related to medical care revolved around privacy and confidentiality of services, provider-client relationship, duration of services, accessibility (cost), follow-up care, referrals, and the actual services received. These questions were only applicable to the health facility-based, hospital-owned OSC model facilities (Mansa, KNH, and MTRH) since the other models did not offer medical care services to clients.

The survivor interview data demonstrated that survivors took different routes in seeking medical care. While some reported to the health facilities in the first instance, others reported to the police before being referred to the health facilities for medical care. Survivor interview data suggests that survivors who reported to the police first tended to perceive sexual violence as more of a legal issue than a health issue. Lack of information on the existence of OSCs, their location and services offered was found to be a key challenge to the accessibility of SGBV services in both Kenya and Zambia. Survivors who seek help at the health facility first are likely to receive timely medical attention and to have their medical reports completed to expedite police action in apprehending the perpetrator.

Apart from accessibility concerns, the assessment found that all survivors interviewed perceived the services as acceptable and highly effective in addressing their medical care needs. The services were considered to provide survivors the much needed privacy and confidentiality while seeking care. All survivors and caregivers who sought services in KNH, MTRH and Mansa were very satisfied with 
providers' engagement with them, the type of questions asked, and the empathy shown by providers. A respondent from Zambia, for instance, had this to say:

Because of the way that they received me, they were able to calm me down because of what had happened to me. Yes, you know when I arrived, I found a nurse who welcomed me and she told me, "I am sorry for what happened to your child. I know that you have pain in your heart, but sorry for that." And when the doctor was asking me questions, I felt that she is somebody who cares about people because of the kind of questions she was asking. ... Just looking at her, I felt that she [had] respect (Caregiver, Zambia).

While there was variance in the amount of time spent at the OSCs, survivors generally were of the opinion that they had spent an appropriate amount of time. Time taken while seeking services depended very much on the queue. Survivors reported that they took a long time on the first visit because of the tests done and the waiting time required to obtain the results. All survivors and caregivers also reported to have received free clinical and psychosocial services. Clinical services received by survivors included physical examination, medical tests, treatment, PEP and EC. Although survivors incurred transport costs to the OSCs, they were satisfied with the services and especially with the fact that they were free. A Kenyan survivor reported:

'To me, where I was I had no money. Then I thought, 'Hospital: Money.' I just went home. So later, after [a] suicide attempt, my friend told me that there are counseling services in Kenyatta [National Hospital] and they are free. I didn't know there's anything free."

It was however found that at the KNH OSC, only survivors of sexual violence received free services, while survivors of other forms of GBV (such as physical violence) paid for all the services. In all other centers, services were free, irrespective of the type of violence experienced.

Interviews with survivors showed that no survivor got pregnant after receiving EC and no side effects were reported.

Apart from the health benefits, the medical care offered by OSCs was also perceived by survivors and their caregivers as facilitating the legal process. Interviews with caregivers of child survivors showed that their motivation for visiting OSCs was not only to receive clinical services, but also to obtain a medical report for taking legal action. A caregiver stated:

"YYou know, I wanted to take legal action against that man, so they examined her and they gave me a report .... You know, this one [her child survivor] was hiding it. When I brought her here, I wanted to get a medical report from the doctor so that I can be able to take legal action." (Caregiver, Kenya)

Overall, survivors perceived that the medical care offered in the health facility-based, hospital-owned OSCs in Zambia and Kenya met their health needs as SGBV survivors. These services did not exist in the other two OSC models run by NGOs. Survivors were particularly satisfied with the fact that the services were largely free and had the potential to facilitate the arrest of perpetrators. 


\section{OSC services and legal outcomes of survivors}

The justice and legal components of OSCs remain key in ensuring that survivors receive sound legal advice, take legal action if they so desire, and that the perpetrators of SGBV are prosecuted. However, the prosecution of perpetrators requires the cooperation of the OSCs with the criminal justice systems of their respective countries. It further requires the cooperation of the survivor with the medico-legal services and the police. This study assessed how the OSC services (in particular, medico-legal services and police/legal services) enhanced legal outcomes for survivors. We were specifically interested in finding out whether the perpetrators had been taken to court, and in the outcome of court cases. Table 4 shows the medico-legal and police/legal services offered in the Kenya and Zambia OSC models.

Table 4: Police/legal services offered by the different OSC models

\begin{tabular}{|c|c|c|c|c|c|}
\hline Services & $\begin{array}{l}\text { Burma } \\
\text { Stand-alone } \\
\text { NGO "owned" }\end{array}$ & $\begin{array}{l}\text { Mazabuka } \\
\text { Hospital based, } \\
\text { NGO "owned" }\end{array}$ & $\begin{array}{l}\text { Mansa } \\
\text { Hospital based, } \\
\text { hospital } \\
\text { "owned" }\end{array}$ & $\begin{array}{l}\text { KNH } \\
\text { Hospital } \\
\text { based, } \\
\text { hospital } \\
\text { "owned" }\end{array}$ & $\begin{array}{l}\text { MTRH } \\
\text { Hospital } \\
\text { based, } \\
\text { hospital } \\
\text { "owned" }\end{array}$ \\
\hline \multicolumn{6}{|l|}{ A: Police } \\
\hline Statement-taking from survivor & Yes & Yes & Yes* & No & No \\
\hline Storage of forensic evidence & No & No & Yes* & No & Yes \\
\hline Issuing the police medical report form & Yes & No & Yes* & No & Yes \\
\hline \multicolumn{6}{|l|}{ B: Paralegal } \\
\hline Opening a docket & No & No & Yes* & No & No \\
\hline
\end{tabular}

*Service is provided within the hospital premises, but not right within the OSC itself.

As mentioned previously, only the NGO-owned OSCs (Burma and Mazabuka) had paralegals and VSU officers on-site. Data in Table 4 show that the NGO-owed OSCs provided a broader range of the requisite police/legal services than the health facility-based, hospital-owned OSCs. Although the two NGO-owned OSCs did not open dockets for survivors, paralegal services are well provided in all Zambian OSCs studied, irrespective of model.

Collection and storage of forensic evidence was provided in two health facility-based, hospitalowned OSCs (Mansa and MTRH). The two hospital-owned OSCs in Kenya (KNH and MTRH) did not provide statement-taking from survivors and others. The health facility-based OSCs $(\mathrm{KNH}$, MTRH) did not provide police and legal services on-site, but referred survivors to police stations and NGOs, respectively. Mansa OSC in Zambia referred clients to a VSU officer outside the OSC itself, but still within the Mansa Hospital premises. 
These findings point to some variability in the legal process as it relates to medical care.

Table 5 indicates that despite many cases being referred to the OSCs, few are processed through the criminal justice system. For instance, of the 1,239 cases referred across all OSCs in this study, about 3 percent (34 cases) were apprehended by police, 2 percent ( 29 cases) were taken to court, and only 0.5 percent $(6$ cases) were convicted. One case was dismissed and another withdrawn once in court since the perpetrator was the bread-winner. Other outcomes reported, in cases referred from the stand-alone, NGO-owned OSC model, included a case where the perpetrator and survivor asked to reconcile, another case referred to social welfare, a case resolved privately between perpetrator and survivor, and a case referred to a VSU officer.

Table 5: Legal outcomes of cases handled by different OSCs*

\begin{tabular}{lccccc}
\hline \multicolumn{1}{c}{ Cases } & Burma & Mazabuka & Mansa & KNH & MTRH \\
\hline Cases referred to OSCs & 465 & 193 & 187 & 194 & 200 \\
Perpetrators arrested by police & 14 & 2 & 5 & 0 & 14 \\
Perpetrators released on bail & 2 & 0 & 0 & 0 & 2 \\
Cases taken to court & 14 & 1 & 1 & 0 & 13 \\
Cases completed & 12 & 1 & 0 & 0 & 4 \\
Outcome of cases & & & 0 & 0 & 4 \\
Perpetrators convicted/guilty & 2 & 0 & 0 & 0 & 0 \\
Cases dismissed & 1 & 0 & 0 & 0 & 1 \\
Cases withdrawn once in court & 1 & 0 & 0 & 0 & 0 \\
\hline Other outcomes & 10 & 1 & & 0 \\
\hline
\end{tabular}

* The data in Table 5 represent the legal outcomes of cases handled by the OSCs during the 24 months prior to the beginning of the study - i.e., 24 months before July 2011 in Zambia and 24 months before September 2011 in Kenya.

The health facility-based, hospital-owned OSC model at KNH appeared to have the weakest link with the criminal justice system. Of all the 194 cases referred, none had led to a police arrest, and no perpetrator had been taken to court. YWCA Burma (the stand-alone, NGO-owned model) and MTRH (the health facility-based, hospital-owned model) had the most effective link with the criminal justice system, with 14 perpetrators being arrested and arraigned in court. Out of those arraigned in court, 4 MTRH cases received a guilty verdict and only 2 YWCA Burma cases received a conviction. This could be attributed to the lack of clinical services that characterizes the standalone, NGO-owned OSC model. It is plausible that the cases had insufficient evidence to sustain the charges in court.

The health facility-based, hospital-owned MTRH OSC emerged as the model with the best legal outcomes for survivors. The medico-legal services provided at this facility plausibly enhance the likelihood of timely and concrete evidence collection, including forensic evidence, which is obtained and preserved before cases are taken to court. MTRH aids in the legal process by having an on-site doctor fill in the police medical report form and provide referrals for those in need of legal 
assistance. Unlike in other OSCs, at the MTRH OSC, the doctor goes to court to give the medical report. With several cases pending in court and four perpetrators convicted - one for life, one for 20 years and two others for 15 years each - the MTRH model provides an ideal OSC model environment where the health workers, police, legal experts, and survivors are working together to ensure legal action against perpetrators.

Of note is the fact that Mansa OSC provided all the police/legal services explored by referring survivors to a VSU outside of the OSC itself, but still with the hospital premises. Nonetheless, the legal outcomes for this OSC were unremarkable, raising questions about existing referral systems between the OSC and the VSU.

\section{Characteristics of successful and unsuccessful court cases}

The four successful court cases referred from MTRH were characterized by the survivors being young (4, 5, 9 and 13 years), female, and victims of defilement. This finding was not unexpected as the sexual assault of children is often considered more socially upsetting; hence, most cases where legal action is actually taken involve parents/caregivers taking the case forward on behalf of children. Prosecution in cases of adult survivors, particularly intimate partners, tends to be more complicated.

At YWCA Burma, the two successful cases involved a one year old child and a female survivor age 32, the GBV experienced being defilement and rape, respectively. In all cases, the perpetrators were men. An unsuccessful case which was dismissed in Burma involved a 39 year old female survivor of rape. Table 6 shows the characteristics of successful and unsuccessful court cases.

Table 6: Characteristics of successful and unsuccessful court cases

\begin{tabular}{lll}
\hline Characteristics & Successful & Unsuccessful \\
\hline Case reported within 72 hrs & Yes & No \\
Police physically visited scene of crime & Yes & No \\
Police collected evidence from crime scene & Yes & No \\
Copy of signed PMR form available & Yes & No \\
VSU officer met survivor on first OSC visit & Yes & No \\
Paralegal officer met survivor on first OSC visit & Yes & No \\
\hline
\end{tabular}

From the findings, it is clear that timely reporting of the cases within 72 hours is essential for the outcome of the cases since this ensures that the evidence is collected and preserved in the same location. The role of police in visiting the crime scene and collecting evidence, as well the role of paralegal and VSU officers in providing legal guidance are also important. These findings underscore the importance of medico-legal services in ensuring that the needs of survivors who would like to take legal action, are served. 


\section{Acceptability of the different OSC models to survivors and caregivers in addressing legal outcomes}

Perpetrator prosecution requires a chain of cooperation including the police, medical care givers, social workers, and survivors. The assessment demonstrates that the legal process remains a major challenge for survivors and for multiple reasons. Where services do not exist, such as in the hospitalowned OSCs (KNH and MTRH in Kenya), where only clinical and psychosocial services are offered, survivors are referred for legal services and may face more difficulties in navigating the legal system. The legal outcomes data from Mansa OSC suggest that referrals for legal services may be challenging even when the referral points are within the same hospital setting.

Although in Kenya there have been efforts to involve the police through SGBV training and the establishment of Gender Desks in police stations, survivors and stakeholders felt that the success of these efforts is limited. The police were perceived as being lax in pursuing evidence, and compromised by bribe-taking (from perpetrators), thereby inhibiting the reporting of SGBV cases. A stakeholder reported the unfair consequences survivors face during reporting of cases,

"We have one girl right now who had been abused by a doctor. So this girl went to get the P3 [PMR] form and she was told that she [should bring along] a witness. She is a young girl who came from Nandi, she is 13 years. So the police demanded [that she] get a witness who was there and she came and reported to us, she was so traumatized" (Stakeholder, Kenya).

Survivors reported that police rarely visit crime scenes, and likewise even more rarely capture perpetrators or complete follow up on cases. A rape survivor who later became pregnant and attempted suicide reported: "In fact, they were so rude. Even going to the crime scene, it took ages for them and yet it was just somewhere so near." The police, in several instances, were also accused of releasing perpetrators, to the dismay of survivors.

The silencing of survivors by family and community members plays a huge role in further weakening the chances of perpetrator prosecution and conviction. Survivors are sometimes silenced by societal pressure to have the cases resolved by community leaders, particularly when the perpetrator is a family member. A caregiver reported:

"W]e want these cases to be taken forward, even if this is a family matter. People are saying, "You should not go there. Don't go to the doctor and don't go to the police." "Let's resolve this matter here at home." That is the problem that we have encountered. Even as we are here right now, the people who abused this child are saying that we should talk about this matter at home. We should not go forward... But when they realized that we have come here, they changed their position because this is something which is going to come out in the open. He was arrested yesterday morning." (Caregiver, Kenya).

Cultural pressure not to participate in the legal process is strong. Survivors who make a police report are expected to cooperate and assist the police during investigations, and to be willing to pursue the case until its conclusion. It was reported, however, that some survivors were silenced by 
their family members, and that, in some cases, the police were bribed. Unsurprisingly, therefore, some survivors were simply reluctant to take legal action. In cases involving a close family member, some survivors understandably preferred the matter to be settled informally.

Stakeholders noted that evidence was sometimes lost when some survivors bathed after the assault, washed their clothes, or reported to the police too late. While awareness creation around the chain of evidence among the general public and the police can contribute to the achievement of optimum reporting and follow-through of SGBV cases, a key challenge is to address the myriad of important reasons why survivors do not seek prosecution (including the many ways in which their case can fall through during the legal process, the retribution they may have to face from their family, community, and/or the perpetrator's family (if different from their own), and that fact that their own healing may demand abstaining from a lengthy and traumatizing legal process).

The health facility-based, hospital-owned OSCs will also need to strengthen their linkages with police/legal systems in order to facilitate the arrest of perpetrators and their arraignment in court rather than assuming that women and children have the stamina to pursue cases on their own. Finally, and perhaps ultimately, shifting the stigma from survivor to the perpetrator who committed the violation must play significantly in any prevention campaigns.

\section{Acceptability of different OSC models to key stakeholders}

Building on previous research from South Africa by Vetten and others (2008), this study also assessed the effectiveness of OSCs on health and legal outcomes of survivors by contextualizing practices surrounding SGBV services for future expansion of effective services in Kenya and Zambia. The OSC models studied in Zambia and Kenya provide physical co-location for at least two SGBV services: clinical and psychosocial services, or psychosocial and legal/justice services. Referrals are then given for the third service required. The health facility-based, hospital-owned OSC models offered medical and psychosocial support, and referred survivors to police or legal aid support from NGOs, or within the same hospital setting (as in the case of Mansa OSC). The NGOowned OSC models offered legal aid/justice and/or psychosocial services, or shelter and/or psychosocial services, and networked with health facilities for clinical services. No single model provided all services in one setting.

The idealized OSC, which offers medico-legal and psychosocial services under one roof, was noted by stakeholders as having many advantages in achieving the anticipated outcomes. Such advantages include enhancing privacy and confidentiality, ensuring access to all the required services, cutting down on transportation costs and time, preserving evidence by eliminating movement from one facility to another, minimizing physical and psychological trauma among survivors, and ensuring continuity and momentum of follow up services by both providers and beneficiaries of services.

Proponents of the 'ideal' OSC argued that although the health facility-based, hospital-owned OSCs excelled in the provision of clinical and psychosocial services, linkages to the legal and justice system for purposes of achieving OSC anticipated outcomes remain weak. The weak linkage was attributed 
to poor coordination among stakeholders and unsustainable funding (e.g., for personnel). Stakeholders argued that without an integrated system, most clients will continue to receive clinical and psychosocial support, but those interested in taking legal action will never realize justice. Stakeholders in the health sector also felt that medical, legal and psychosocial services should be provided in one physical location. An informant stated:

"We need a laboratory, a medical room and so on. We need a medical practitioner specifically for gender issues $[G B V]$. We need shelter for survivors, we need a police desk and a lawyer stationed here."

While the NGO-owned stand-alone and the health-facility based, NGO-owned models were perceived to have a strong legal components, their medical and referral systems were weak. Stakeholders argued that this hindered the models from achieving the objective of an OSC, which is to match medical, legal and psychosocial support services. It was noted that medical care is not only crucial for survivors' healing process, but also for adducing evidence to permit legal action by survivors, when desired.

\section{Cost of delivering OSC services}

Another key objective of this assessment was to determine the cost per client of delivering services in each of the OSC models examined in Kenya and Zambia. To estimate these costs, systematic evidence on the cost of setting up and operating an OSC, using the accounting approach, is presented.

The accounting approach (also referred to as the 'ingredients approach') makes use of the quantities and prices of an individual SGBV case and sums it over the expected number of cases in a given setting. The basic configuration is to enumerate specific ingredients or inputs for each case, estimate the quantity of each ingredient, and multiply by its estimated price. This product is then summed up over the ingredients of one client. The cost of responding to all clients in a given setting (such as an OSC or any other geographical area) is then obtained by multiplying the product by the estimated number of clients.

Mathematically:

$C=X \sum_{\mathrm{i}=1}^{\mathrm{n}} Q_{\mathrm{i}} P_{\mathrm{i}}$

Where $\mathrm{Q}_{\mathrm{i}}$ is the quantity of ingredient $\mathrm{i}$

$P_{i}$ is the price of each unit of ingredient $i$

$\mathrm{X}$ is the number of persons treated for SGBV

$\mathrm{C}$ is the cost of treating SGBV.

The data required thus fall in three categories: 1) the number of cases; 2) the quantities of each ingredient used; and 3) the price of each ingredient. 
There were difficulties in obtaining complete information for hospital-based OSCs, particularly in Kenya. Consequently, cost estimates are provided for Zambia alone.

\section{The number of clients}

The number of clients in a year seen at each of the OSCs was captured through the facility inventory form as the primary source of data. Each facility was asked to record the total number of clients received in a period of 12 months from January 1 to December 31, 2010. In all cases (except for in the case of YWCA Burma in Zambia ${ }^{x y}$, these data were provided. In addition, the data provided for Kenyatta National Hospital was deemed an underestimate based on the facility's size and function. To correct these two anomalies (the lack of client data for YWCA Burma and the underestimate for $\mathrm{KNH}$ ), an expected number of clients was computed for each of the 5 health facilities across the two countries. This was based on the total individual client record reviews in each study site. The expected number of clients for Mazabuka, Mansa, and MTRH are consistent with that reported on the facility inventory form. The expected number of clients for YWCA Burma and KNH form the estimates.

Following a comparison of the total number of clients as recorded on the facility inventory forms and information obtained from individual client record reviews in each study site, the expected number of clients was estimated based on weights. The exception to this process was MTRH in Kenya. Unlike other study sites, the estimated total number of clients recorded for MTRH on the facility inventory form was consistent with the individual client record data in this setting.

\section{Start-up costs}

Health facility-based, hospital-owned OSCs share the commonality of being set up within an existing infrastructure. This trait poses challenges for identifying, teasing out, and measuring start-up expenses. In the health facility-based hospital-owned OSC models surveyed (KNH and MTRH of Kenya, and Mansa General Hospital of Zambia), data on start-up costs could therefore not be distinguished from the general costs of hospital operations. On the other hand, in the case of NGOowned OSCs, it was possible to make this distinction and therefore estimate the costs of set-up (see Table 7).

Table 7: Start-up expenses for One-Stop Centers for SGBV (US\$)

\begin{tabular}{|l|c|c|}
\hline \multicolumn{1}{|c|}{ Expenses } & $\begin{array}{c}\text { Health facility } \\
\text { based, NGO } \\
\text { "owned" OSC } \\
\text { Mazabuka }\end{array}$ & $\begin{array}{c}\text { Stand-alone, } \\
\text { NGO "owned" } \\
\text { OSC } \\
\text { YWCA } \\
\text { Burma }\end{array}$ \\
\hline Staff time dedicated to personnel recruitment & 5,068 & - \\
\hline General expenses & 1,160 & 5,885 \\
\hline Medical equipment & & \\
\hline Non-medical equipment & 34,221 & 29,834 \\
\hline Renovation & 5,620 & - \\
\hline Total & 46,069 & 35,719 \\
\hline
\end{tabular}


Mazabuka and YWCA Burma alike do not provide clinical services, apart from HIV counseling, and therefore do not incur medical equipment costs. As they are located in pre-existing establishments, equipment accounts for over 80 percent of the start-up costs. The remaining costs are expended in personnel recruitment, and general expenses. The details of the non-medical equipment costs are shown in Table 8. The motor vehicle is the largest single cost to setting up OSCs for SGBV.

Table 8: Cost of non-medical equipment in US\$

\begin{tabular}{lcc}
\hline \hline & YWCA Burma Rd & Mazabuka \\
\hline Office tables & 1,805 & 640 \\
Office chairs & 1,974 & 789 \\
Office cabinets & 717 & 1,240 \\
Visitors chairs & - & 341 \\
Office computers & 3,114 & 3,701 \\
LCD projector & - & - \\
Printers & 965 & 571 \\
Photocopiers & 1,462 & 1,365 \\
Telephones & 75 & - \\
Fax machines & 306 & - \\
Television sets & 232 & 487 \\
Refrigerators & 487 & 420 \\
Moto Vehicle & 17,312 & 18,000 \\
Digital Camera & - & 351 \\
Decoder & - & 422 \\
Scanner & - & 274 \\
Bookshelves & 1,170 & - \\
Cooker & 214 & - \\
\hline Total & $\mathbf{2 9 , 8 3 4}$ & $\mathbf{2 8 , 6 0 1}$ \\
\hline \hline
\end{tabular}

\section{Number of clients and services provided at various OSCs}

In order to estimate the cost per case of managing SGBV at one-stop centers, knowledge of the number of clients received during a given period is important. Figure 1 shows the estimated number of clients seen in the year 2010 in all five facilities. The results are displayed from the highest number of clients received to the lowest. YWCA Burma Road is estimated to have seen more clients in 2010 compared to other health facilities. Health facility-based, hospital-owned OSCs are estimated to have seen fewer clients compared to NGO-owned OSCs (whether stand-alone or health facility-based). In addition, Kenyan OSCs are estimated to have seen fewer clients than OSCs in Zambia. The difference noted between client loads in Kenya and Zambia is remarkable and suggests that further research on conditions of service uptake would be a worthwhile undertaking. 
Figure 1: Total number of clients seen at the facility in the year 2010

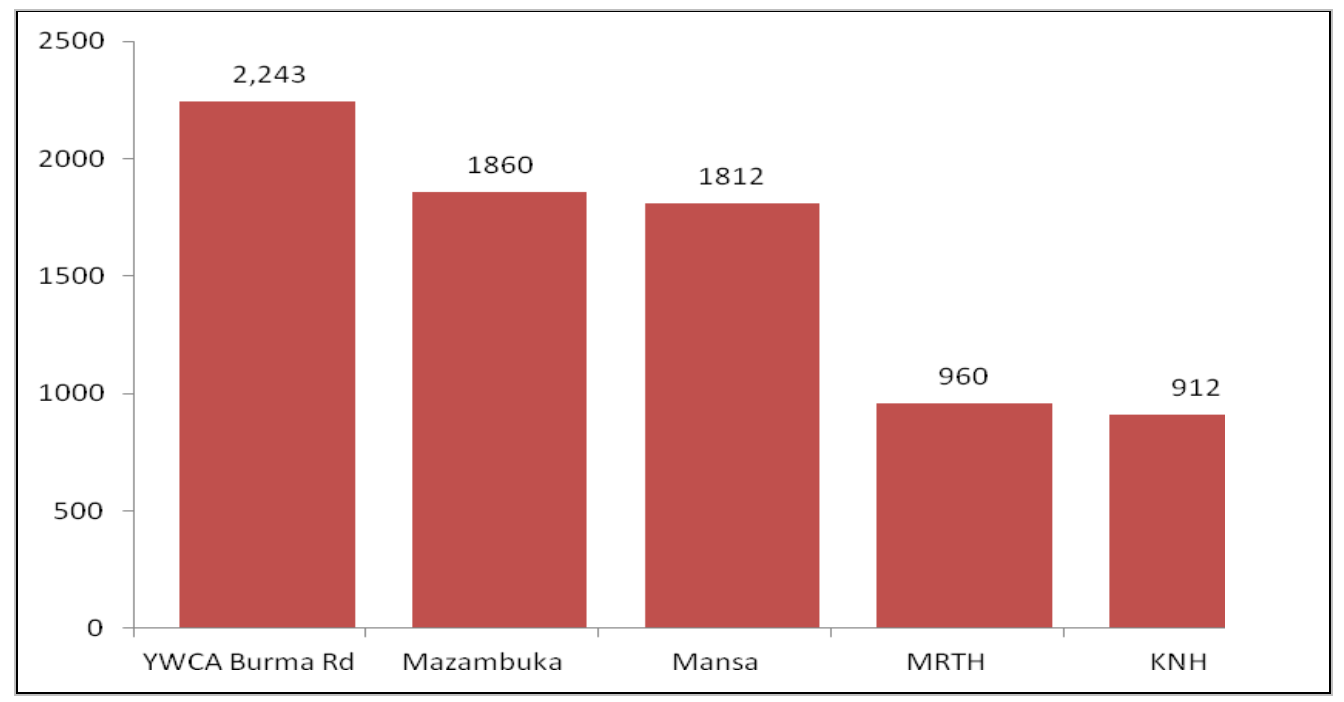

\section{Operational costs}

Operational costs of OSCs are diverse depending on the services provided. In this study, the operational costs of staffing and general expenses related to the provision of services were considered. The staff costs are shown in Table 9. YWCA Burma and Mazabuka of Zambia do not have staff members in the following categories: obstetricians and gynecologists, pediatricians, general practitioners, and midwives/nurses. Of the two sites, Mazabuka alone provides HIV counseling but not testing. Mansa General Hospital, on the other hand, provides clinical services and therefore has two general practitioners (not costed), 1 clinical officer, and 4 nurses. Part of the reason why the one-stop centers at MTRH and KNH of Kenya are not administratively heavy is because these onestop centers are integrated within the existing institutional and operational set-up of the hospitals concerned, and costs were therefore difficult to isolate. Consequently, the cost per case is not provided for these two Kenyan OSCs.

The general expenses of OSCs are shown in Table 10. The items are mainly operational in nature, including costs such as rent, water, electricity, stationary, motor vehicles, etc. In the case of Mazabuka, exemptions were provided for rent, water and electricity. In the case of YWCA Burma, rent was exempted. No estimates were possible for the other three OSCs, due to data limitations. 
Table 9: Staff costs (total annual expenses on remuneration - salary and allowances)

\begin{tabular}{lccccc}
\hline \multicolumn{1}{c}{ Health Facility } & Burma & Mazabuka & Mansa & MTRH & KNH \\
\hline Obs. \& gyn. & - & - & - & - & 380 \\
Pediatrician & - & - & - & - & - \\
General practitioner & - & - & - & 821 & 851 \\
Clinical officer & - & - & 34,464 & - & - \\
Nurse/ Midwife & - & - & 4,561 & 37 & 672 \\
Counselor & 12,671 & 15,205 & 16,725 & 89 & 507 \\
VSU officer & 12,164 & 4,942 & - & - & - \\
Paralegal & 3,041 & 2,534 & - & - & - \\
Site manager & 16,472 & 15,205 & - & - & 284 \\
Data Entry Clerk & 2,534 & 2,534 & - & 51 & 811 \\
Driver & 3,294 & 3,801 & - & - & - \\
Cleaner/ Office Assistant & 1,774 & 1,774 & 2,027 & - & - \\
Guards & 3,548 & 2,534 & - & - & - \\
Total & 55,497 & 48,528 & 57,778 & 1,498 & 3,505 \\
Cost per case & 24.7 & 26.1 & 31.9 & & \\
\hline
\end{tabular}

The combined costs of staff, general expenses and annualized set-up costs are presented in Table 11. The average cost per client is estimated at about US\$33.50 per year for the health facility-based, NGO-owned OSC, Mazabuka. The cost per client for YWCA Burma, a stand-alone, NGO-owned OSC in Zambia, is estimated at US\$31.00.

Table 10: General expenses at static facility in US\$

\begin{tabular}{lcc}
\hline Item & Mazabuka & YWCA Burma \\
\hline OSC space rentals & exempted & exempted \\
Water bill & exempted & 351 \\
Electricity bill & exempted & 468 \\
Telephone bill & 1,053 & 819 \\
Internet connection & 737 & 936 \\
Stationery/ postage & 158 & 187 \\
Materials production/printing & - & 3,022 \\
Repairs to equipment & 789 & 789 \\
Legal expenses (not service) & 175 & 1,404 \\
Cleaning materials, toiletries & 4,632 & 1,216 \\
Motor vehicle spares & 117 & - \\
Motor vehicle servicing costs & 1,949 & 2,339 \\
Motor vehicle insurance & 975 & - \\
Motor vehicle license fees & 88 & - \\
Total & 10,672 & 11,531 \\
\hline Cost per case & $\mathbf{5 . 7}$ & $\mathbf{5 . 1}$ \\
\hline
\end{tabular}


Table 11: Total annual costs in US\$

\begin{tabular}{lll}
\hline Item & Mazabuka & YWCA Burma \\
\hline Labor costs & 48,528 & 55,597 \\
Annualized Set-up (15 years of life) & 3,071 & 2,381 \\
\hline General costs & 10,672 & 11,531 \\
\hline Total costs & 62,271 & 69,509 \\
\hline Cost per case & 33.5 & 31.0 \\
\hline
\end{tabular}

The results suggest that it costs between US\$35,719 and US\$46,069 to start up an NGO-owned one-stop center as a stand-alone structure, or as part of a health facility. It also costs between US $\$ 24.7$ and US\$26.1 per client per year for staff salaries to run these kind of establishments. It costs about US $\$ 31.9$ per client per year for staff salaries to run a health facility-based, hospitalowned one-stop center.

There is no significant difference in the start-up costs between the NGO-owned OSC models. Startup costs for the health facility-based, hospital-owned OSC models could not be derived because services offered within this model are integrated within the hospital set-up. In terms of operational costs, there is also no significant difference between the two NGO-owned OSC models (one, a stand-alone, and the other, health facility-based), while there is a slight difference between them and the health facility-based, hospital-owned OSC model.

\section{Lessons Learned in OSC implementation}

- The health facility-based, hospital-owned OSC model is best-suited for achieving the broadest range of health and legal outcomes. NGO-owned OSC models offered strong psychosocial support and survivors presenting at these OSCs were more likely to be receive counseling during their first visit than their peers that presented at hospital-owned OSCs. However, given their hospital location, health facility-based, hospital-owned OSCs have the capacity to offer a range of services to survivors, including psychosocial support and medical services to survivors. These OSCs have the relevant infrastructure, equipment, supplies and staff to offer required services. As a result, this OSC model is better placed to meet the needs of survivors more comprehensively. Immediate clinical needs, including treatment for physical injury, PEP, ECP, HIV counseling and testing, and treatment for other STIs, could be met at health facility-based, hospital-owned OSCs. These services are not only fundamental in restoring the health of survivors, but also in the collection and preservation of evidence needed to take legal action.

- A multi-disciplinary team of staff ensures the best health outcomes for survivors. An OSC should have, at the minimum, a doctor, social worker, nurse, and counselors (or nurse counselors), all of whom are trained in child-specific care, and in having sensitive, non-judgmental attitudes toward SGBV survivors. This will ensure that survivors are effectively treated, taken through 
relevant tests and counseled as soon as they report to the OSC. Collection of medical evidence to feed into any legal processes would also be guaranteed. At the same time, care must be taken to ensure the maintenance of a survivor-centered approach within OSCs - an approach that centers on the specialized needs of survivors, some of whom may not want to take legal action.

- Psychosocial support services should include support groups for SGBV survivors. Support groups were found to help survivors share their experiences with other survivors, thereby facilitating their healing process. Support groups formed a part of most OSC models in the study.

- Signing of the police medical report forms should take place within OSCs. The forms were only being signed at one health facility-based, hospital-owned OSC, and by a doctor. Advocating for nurses (who tend to outnumber doctors in OSC settings) to complete examinations and sign forensics forms could enhance the quality of care for survivors while lessening the burden on physicians. Although this new role for nurses has been introduced in Kenya's national guidelines for the medical management of SGBV survivors (for example), efforts need to be made to ensure that this is operationalized.

- Collection and storage of forensic evidence by OSCs is critical. This ensures that vital evidence is preserved as survivors receive care. Since the criminal justice system requires a higher burden of proof for SGBV cases, forensic evidence will enhance the chances of convicting perpetrators, should survivors wish to pursue this route.

- Provision of legal services, including legal advice and court preparation, enhances legal outcomes. Timely legal advice provides survivors with needed knowledge to understand that SGBV is not only a medical issue, but also a criminal offence which may be prosecuted if a survivor so desires. Given that survivors are often not aware of the legal/justice channels to follow, provision of legal services will go a long way in reminding survivors of their legal rights. A critical focus of such efforts, however, should be on legal counsel for survivors to aid them in coming to an informed personal decision that is most appropriate for their individual healing, bearing in mind that this decision might not always lead to legal action.

- Integration of medico-legal, psychosocial support and police services in one physical (but not 'stand-alone') location should be promoted. SGBV survivors reporting to such OSCs will obtain all the required services necessary for achieving health (including psychosocial) and legal outcomes in one place. This addresses the accessibility and staffing concerns that were found to inhibit the operation of OSCs.

- The needs of child survivors of SGBV have to be better integrated into all levels of OSC services. A major gap in the OSC models reviewed has to do with child-focused needs in regard to social welfare or general protective services. These need to be incorporated as an integral component of any OSC model and should be taken into account when recruiting and/or training OSC staff. 


\section{RECOMMENDATIONS FOR INTRODUCTION AND SCALE-UP}

Based on the findings, a number of suggestions can be made for the introduction and scale-up of OSCs in Kenya and Zambia.

\section{Infrastructure}

- There is need to establish "ideal” OSCs offering comprehensive SGBV services including clinical, psychosocial and legal to meet the needs of survivors in one physical location. This will address accessibility concerns such as distance and cost of transport to OSCs.

- Given the current SGBV landscape where all services are not offered in one physical location, there is need to strengthen the linkages between different service points in order to achieve comprehensive SGBV services. This will require coordination between the medical and psychosocial support services, and the police department and legal institutions in order to enhance the survivors' pursuit of justice.

\section{Staffing}

- OSCs should need to be adequately staffed, ideally with at least one medical doctor, nurse, social worker, paralegal officer, VSU officer, and counselors. However, given the reality that this model can be very costly for hospitals with sparse human resources, it is recommended that in addition to a full-time counselor, at a minimum, one doctor and one nurse should be 'on call' for SGBV on a 24-hour basis, and designated to prioritize attending to SGBV survivors above other casualty responsibilities. This will not only ensure timely response to the medical and psychosocial support needs of the survivors, but also the collection and preservation of evidence and subsequent linkages with the legal/police for investigations.

- Health workers, social workers, and the police need to be better and more frequently trained on SGBV so that they can detect and appropriately handle both child and adult cases when they come across them in their line of duty. National training guidelines should be produced where they do not exist and in line with SGBV or violence against children (VAC) polices and medical management. Curricula for nursing and medical schools should contain GBV and VAC modules. Care of the child survivor is distinctly different than that of the adult survivor and needs to be recognized as part of training. It is critical that OSC staff are capable of providing child-friendly services. Improved training will enhance the collection and preservation of evidence while survivors will benefit from improved care that minimizes trauma.

- OSCs which do not provide medical services should develop strong referral systems which link them with health facilities. Health workers in general must be made aware that they are dealing 
with a criminal offence and informed of what they need to do before referring clients elsewhere for further support. MTRH OSC worked with lower level facilities within its catchment area and was able to ensure the proper handling of many survivors prior to issuing referrals.

- It would be pragmatic to ensure that trained nurses within OSCs have the legal right to perform forensic examinations, and to sign the medical forms necessary for ensuring that evidence can be entered into court.

\section{Funding}

- Funding for OSCs needs to be adequate and sustainable. Where activities are underfunded or funds run out, the brunt is borne by survivors, who may experience a delay in obtaining muchneeded medical care, as well as their desired legal outcomes. While it is reasonable to start-up an OSC with donor funds, local funding options should be explored early in the process to ensure continuity of services. CARE's ASAZA project in Zambia provides a useful example of OSC set-up and institution-building by an NGO, coupled with eventual hand-over of OSCs to the Zambia Ministry of Health.

- The cost of starting up OSCs could be leveraged where the center concerned is established within a health facility. Such OSCs are also likely to benefit from other economies of scale, including access to hospital staff, infrastructure, equipment and supplies. That said, it is important for OSC models developed to be replicated and reasonably costed in order for countries to plan for the expansion of quality services in an appropriate manner. 


\section{CONCLUSION}

In conclusion, the health facility-based, hospital-owned OSC model appears to be the most ideal model for ensuring medico-legal outcomes, especially when there is a strong linkage with legal aid centers and the police department, as was the case with MTRH. Compared to the other models in this assessment, it would be the most appropriate model for scale-up in both Kenya and Zambia. It offers comparative advantages in terms of costs of start-up, availability of medical staff, equipment, supplies, and infrastructure. The model is also easier to sustain, being built in to a pre-existing hospital structure, and mitigates the risks of stigmatizing survivors, given that it is not a stand-alone structure. 
ii "Gender-based violence" (GBV) refers to all forms of violence and/or physical, mental, economic or social abuse that happen to women, girls, men and boys because of their gender. GBV includes violent acts such as rape and other forms of sexual abuse and sexual slavery, domestic violence, human trafficking, economic and social abuse, and harmful traditional practices such as early or forced marriage, female genital mutilation, sexual cleansing and property grabbing. World Health Organization. 2003. Throughout this report, however, the term "SGBV" is used, rather than "GBV" in order to make the distinction between sexual violence and genderbased violence. Although some violence is gender-based, not all forms are. The term "sexual and gender-based violence" therefore comprises male-on-male (children and adult) violence, for example. On the other hand, the term "GBV" does not include these types of violence as it refers only to violence that is between the genders.

iii For more information on the basic components of the OSC model in humanitarian settings more generally, see UNICEF (n.d.).

iv Workshop report on the establishment of one stop centers and referral mechanism for survivors of sexual and gender based violence held on 6 th- 7 th $^{\text {th }}$ December 2010 at Nairobi Safari Club, Nairobi Kenya. Task Force on the Implementation of the Sexual Offences Act in collaboration with UNODC and GTZ.

v Mazabuka and YWCA Burma OSCs are two of eight Coordinated Response Centers (CRCs) for SGBV in Zambia that were operating under the ASAZA project at the time of the study. It is important to note that other CRCs in Zambia had/have medical staff on-site, unlike Mazabuka and YWCA Burma at the time of this particular study.

vi See above comment.

vii The $A$ Safer Zambia (ASAZA) project was a CARE Zambia-led SGBV Coordinated Response Program funded by the United States Mission under the Presidential Women's Justice and Empowerment Initiative (WJEI) and the European Union (EU) grant for the Expansion of the Coordinated Response to SGBV in Zambia. Other partners in ASAZA include World Vision Zambia, Young Women's Christian Association, Women and Law in Southern Africa, Catholic Relief Services, International Justice Mission, Zambia Police-Victim Support Unit, Child Justice Forum, and the Ministry of Health. Although two of the Zambia OSCs included in this study (Mazabuka and YWCA Burma) were being managed by the ASAZA project during data collection, the ASAZA project came to an end in December 2011. Since that time, the OSCs, or 'Coordinated Response Centers' (CRCs) have been under the management of the Ministry of Health, and are now funded by the government (USAID and CARE, 2011). Currently, World Vision provides technical support to the Ministry of Health in the operation of the CRCs.

viii See Appendix for study tools.

ix We acknowledge that there are myriad costs to survivors associated with seeking services, including intangible costs, such as the opportunity costs of lost time. However, personal costs of survivors (e.g., transportation to facilities, cost of health examinations, administrative costs for examination forms and patient file opening where these are not free, etc.) were not factored into the costing model.

x Report on Conference Proceedings of the Sexual and Gender Based Violence: First Annual Coast Policy Conference, December, 2010.

xi It should be noted that there is an overlap between these documented forms of gender-based violence, as intimate partner violence can be physical and/or sexual, and more (e.g., psychological, economic).

xii Defined as 'forced or consensual anal intercourse, usually between male-to-male' USAID \& CARE (2011:49).

xiii As stated in the simplified version of Kenya's Sexual Offences Act (2006:3), '[A] child is anyone below the age of 18 years. Having sexual intercourse with a child is illegal and any person who has sex with a child is guilty of the offence called defilement, even if the child agreed to have sex with that person.'

xiv The most commonly-reported forms of violence in Zambia were (non-sexual) physical violence (32\%), emotional abuse (21\%), and child neglect $(12 \%)$.

xv At the time of data collection, this particular health facility was unable to make these data available. 


\section{REFERENCES}

Baxter P and Jack S, 2008. Qualitative case study methodology: study design and implementation for novice researchers. The Qualitative Report 13(4): 544-559.

Bramsen, Elklit, Nielsen, 2009. Danish model for treating victims of rape and sexual assault: the multidisciplinary public approach. Journal of Aggression, Maltreatment, and Trauma 18: 886-905.

Brown D, Riley L, Butchart A, Meddings R, Kann, L and Harvey A. 2009. Exposure to physical and sexual violence and adverse health behaviours in African children: results from the Global Schoolbased Student Health Survey. Bulletin of the World Health Organisation. 87:447-455.

Chomba E, Murray L, Kautzman M et al., 2010. Integration of services for victims of child sexual abuse at the university teaching hospital one-stop centre. Journal Tropical Medicine. Epub 2010 Jul 14.

Heise, L, Ellsberg, M, and Gotemoeller, M. 1999. Ending violence against women: Populations reports volume 27, number 4. Baltimore: Johns Hopkins University, School of Public Health

Jones, Lisa, 2009. Executive Summary: findings from a UNH multi-site evaluation of children's advocacy centers (CAC). www.unh.edu/ccrc/multi-site evaluation children.html

Jehle, GA and Reny, PJ. 2001. Advance microeconomic theory. London: Addison Wesley.

Keesbury J and Askew I, 2010. Comprehensive responses to gender based violence in low-resource settings: Lessons learned from implementation. Population Council. Lusaka, Zambia.

Kenya National Bureau of Statistics (KNBS) and ICF Macro. 2010. Kenya Demographic and Health Survey 2008-09. Calverton, Maryland: KNBS and ICF Macro.

Munalula, C and Kanyengo, B 2011. A Safer Zambia (ASAZA): Model for a Coordinated Response to GBV under the Women Justice Empowerment Initiative (WJEI) Program. Care International. Presentation at the Africa Regional SGBV Network Annual Partners Meeting, February 7-10, 2011, Lusaka, Zambia (http://www.svri.org/ASAZA.pdf).

MEASURE Demographic Health Survey, Zambia, 2007. http://www.measuredhs.com/pubs/pdf/FR211/FR211\%5Brevised-05-12-2009\%5D.pdf

Miller A and Rubin D, 2009. The contribution of child's advocacy centers to felony prosecutions of child sexual abuse. Child Abuse \& Neglect 33:12-18.

Newman B, Dannenfelser P, and Pendleton D, 2005. Child abuse investigations: reasons for using child advocacy centers and suggestions for improvement. Child and Adolescent Social Work Journal. 22 (2): 165-181. 
Population Council, 2008. Sexual and gender-based violence in Africa: Key issues for programming. Population Council: Nairobi, Kenya.

Population Council, Sida, and ICRH, 2010. Sexual and gender based Violence: First Annual Coast Policy Conference, 2010 report on conference proceedings.

Reza A, Breiding MJ, Gulaid J, Mercy JA, Blanton C, Mthethwa Z, Bamrah S, Dahlberg LL, Anderson M. (2009). "Sexual violence and its health consequences for female children in Swaziland: A cluster survey study." The Lancet. 373 (9679):1966-1972.

Snell L, 2009. "Child Advocacy Centres: one stop on the road to performance-based child protection.” The Reason Center Policy Study No. 306.

http://www.policyarchive.org/handle/10207/bitstreams/5820.pdf

Stavropoulos J. 2006. Violence against Girls in Africa: A Retrospective Survey in Ethiopia, Kenya and Uganda. Addis Ababa: African Child Policy Forum

UNAIDS. 2006. Violence against Women and Girls in the Era of HIV/ AIDS: A Situation and Response Analysis in Kenya, June 2006. UNAIDS.

Undie C, Maternowska MC, Mak'anyengo M, Keesbury J, Askew I, 2012. Routine screening for IPV in public health care settings in Kenya: An assessment of acceptability. APHIA II OR Project in Kenya/ Population Council: Nairobi, Kenya.

UNICEF (n.d.). Briefing not on coordinated care responses to survivors of sexual violence in postconflict settings: What are the options?

UNICEF, CDC, Together for Girls, Government of Kenya, 2012. Summary Findings and Response Plan: Violence against Children in Kenya, Findings from a 2010 National Survey.

Nairobi, Kenya: UNICEF Kenya, Division of Violence Prevention, National Center for Injury Prevention and Control, Centers for Disease Control and Prevention, the Government of Kenya.

UNICEF, CDC, MUHAS, 2011. Violence against Children in Tanzania: Findings from a National Survey, 2009. Summary Report on the Prevalence of Sexual, Physical and Emotional Violence, Context of Sexual Violence, and Health and Behavioural Consequences of Violence Experienced in Childhood. Dar es Salaam, Tanzania: UNICEF Tanzania, Division of Violence Prevention, National Center for Injury Prevention and Control, Centers for Disease Control and Prevention, and Muhimbili University of Health and Allied Sciences, 2011.

USAID, CARE, 2011. ASAZA (A Safer Zambia) Final Narrative Report: February 2008 to December 2011. Unpublished report. 
Vetten L, Jewkes R, Sigsworth R, Christofides N, Loots L, Dunseith O, 2008. Tracking Justice: The attrition of rape cases through the criminal justice system in Gauteng.Johannesburg: Tshwaranang Legal Advocacy Centre, the South African Medical Research Council and the Centre for the Study of Violence and Reconciliation. Available at: http://www.tlac.org.za/wpcontent/uploads/2012/01/Tracking-Justice.pdf

World Health Organization. 2003. Guidelines for medico-legal care for victims of sexual violence. Geneva: World Health Organization. Geneva: World Health Organization.

Zimbabwe National Statistics Agency, 2012. National Baseline Survey on Life Experiences of Adolescents (Preliminary Report) 2012. 


\section{APPENDICES}

\section{Appendix 1: Facility inventory tool}

Instructions to the data collector: Please request that the in-charge of each facility assist you in completing this form.

The objectives of this process are to:

\section{Document the presence of core elements of each OSC model}

2. Gather costing data for key components of OSC model

Remember that the objective of the inventory is to identify equipment and facilities that currently exist and are in working order-and not to evaluate the performance of the staff or clinic.

You are required to directly observe the conditions indicated on this form. In all cases you should verify that the items exist by actually observing them yourself - if you are not able to observe them, then code accordingly. For each item, circle the code most suitable response or describe as appropriate. Some questions will require additional information to be written in the indicated blank.

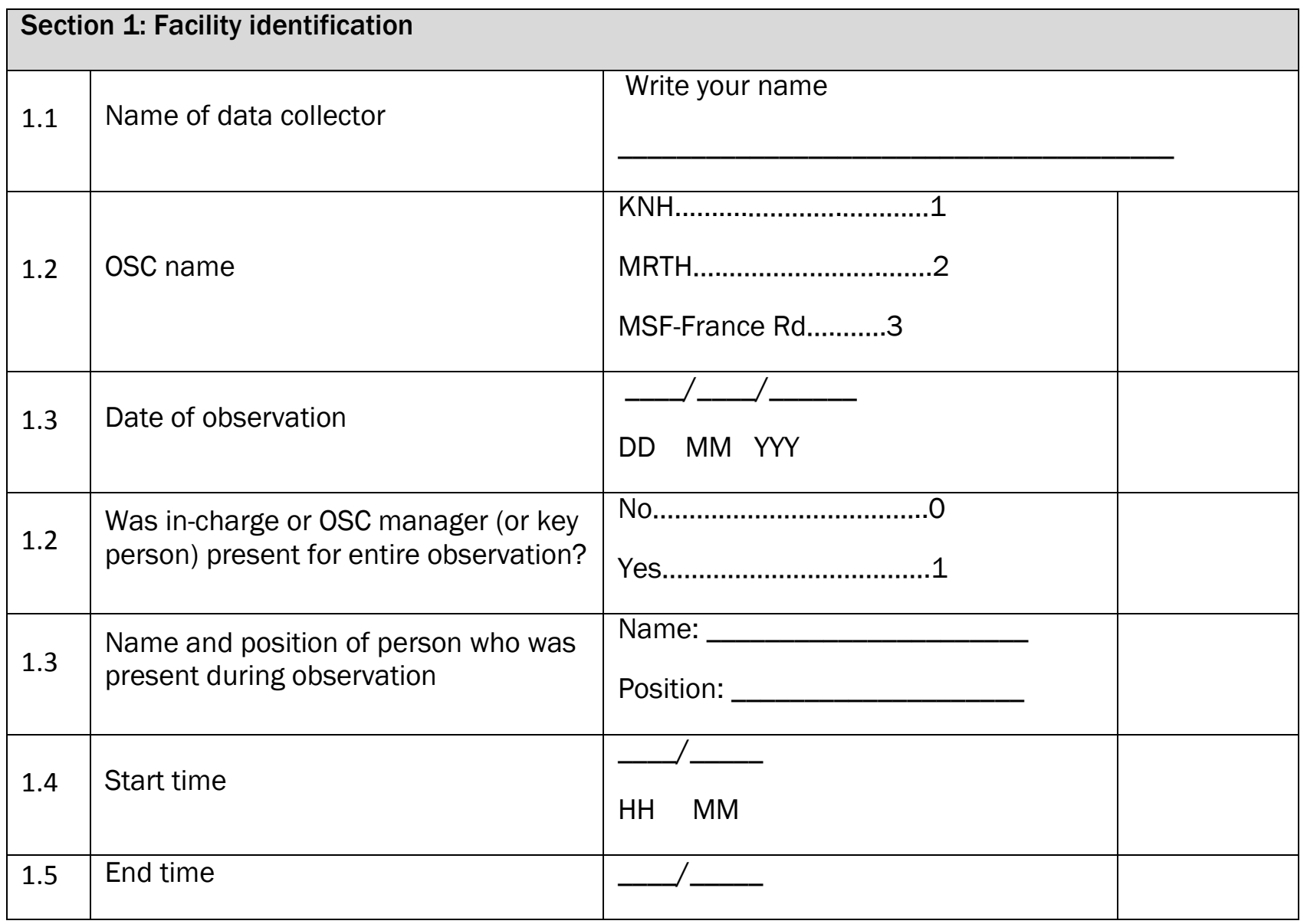




\begin{tabular}{|c|c|c|c|c|c|}
\hline & \multicolumn{4}{|c|}{$\begin{array}{l}\text { Section 2: Service availability } \\
\text { This section should be completed with the assistance of the facility-in charge or knowledgeable staff who can } \\
\text { provide the following information. No direct observations are required for this section. }\end{array}$} & \multirow[b]{2}{*}{$\begin{array}{l}\text { Situation now } \\
\text { (2011) }\end{array}$} \\
\hline & & & $\begin{array}{l}\text { Situation in } 1^{\text {st }} \\
\text { year }(2006 \text { or } \\
2008)\end{array}$ & $\begin{array}{l}\text { Situation in } \\
2010\end{array}$ & \\
\hline 2.2 & Where is this OSC located? & $\begin{array}{l}\text { Within hospital/health center.........1 } \\
\text { On hospital grounds......................... } \\
\text { Not located in a health facility.......... }\end{array}$ & & & \\
\hline 2.3 & $\begin{array}{l}\text { What month and year did this OSC } \\
\text { open? }\end{array}$ & & $\overline{\mathrm{MM}} / \mathrm{YY}$ & & \\
\hline 2.4 & $\begin{array}{l}\text { On WEEKDAYS, during what hours } \\
\text { does this OSC operate? }\end{array}$ & $\begin{array}{l}\text { Opening time } \frac{}{\mathrm{HH} / \mathrm{MM}} \\
\text { Closing time } \frac{}{\mathrm{HH} / \mathrm{MM}}\end{array}$ & $\longrightarrow$ & $-1-$ & $\longrightarrow$ \\
\hline 2.5 & $\begin{array}{l}\text { On Saturdays . during what hours } \\
\text { does this OSC operate? }\end{array}$ & $\begin{array}{l}\text { Opening time } \frac{}{\mathrm{HH} / \mathrm{MM}} \\
\text { Closing time } \frac{}{\mathrm{HH} / \mathrm{MM}}\end{array}$ & $\longrightarrow$ & $-1-$ & 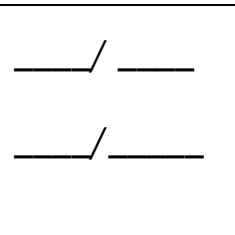 \\
\hline 2.6 & $\begin{array}{l}\text { On Sundays. during what hours } \\
\text { does this OSC operate? }\end{array}$ & $\begin{array}{l}\text { Opening time } \frac{}{\mathrm{HH} / \mathrm{MM}} \\
\text { Closing time }\end{array}$ & 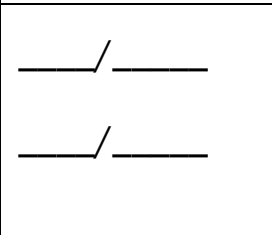 & $-1-$ & 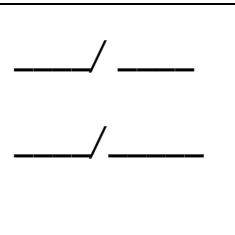 \\
\hline
\end{tabular}




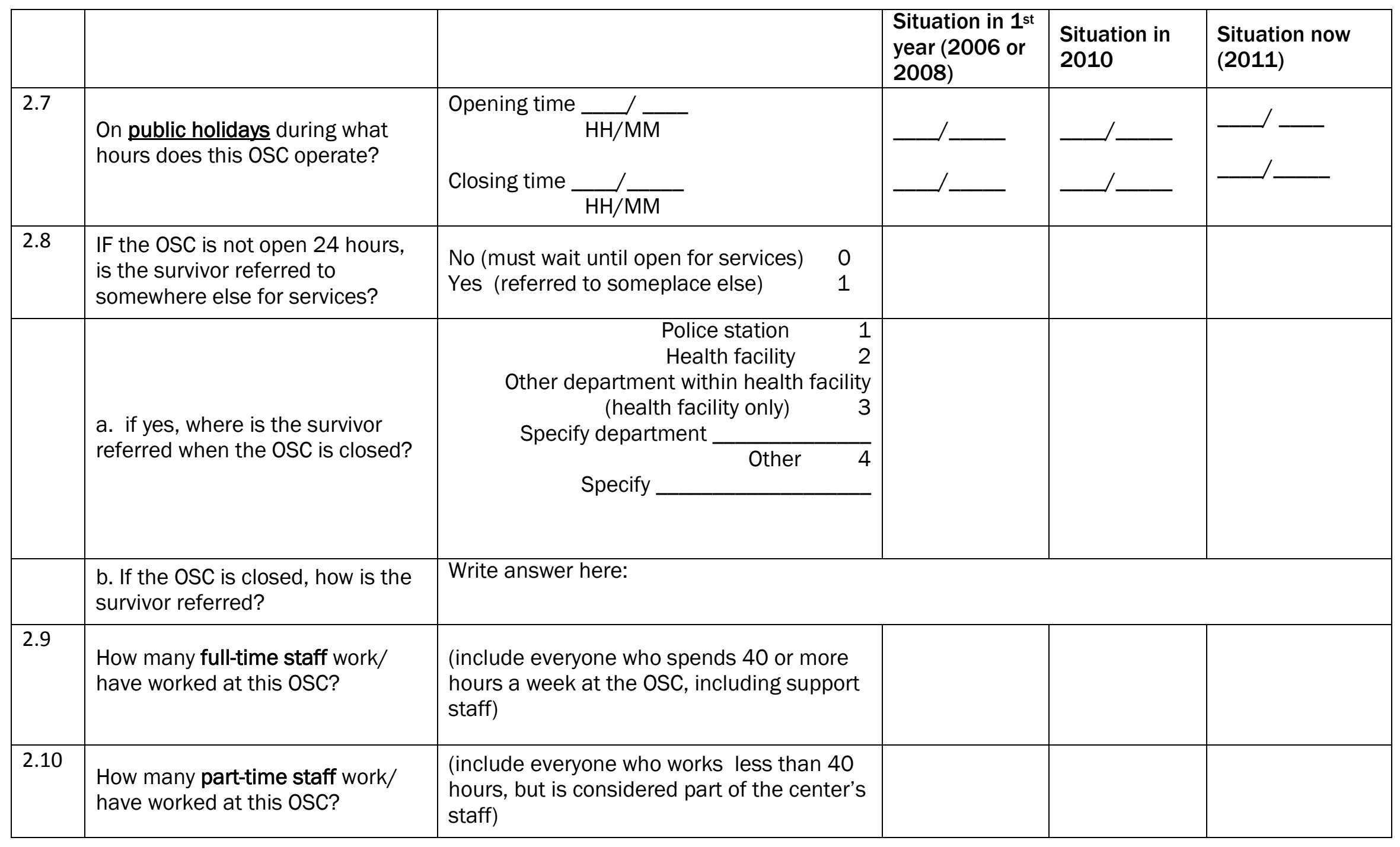




\begin{tabular}{|c|c|c|c|}
\hline Obtai & is information from the OSC's database. If it is not & ailable, the data collectors will need tc & nanually tabulate from the records \\
\hline \multirow[b]{2}{*}{2.11} & \multirow[b]{2}{*}{ Dates of 12-month periods } & $\begin{array}{l}\text { First } 12 \text { months of operation ( } 2006 \\
\text { or } 2008)\end{array}$ & \multirow{2}{*}{$\begin{array}{l}\text { Client load for } 2010 \\
\text { Year beginning: January 1, } 2010 \\
\text { Year ending: December 31, } 2010\end{array}$} \\
\hline & & $\begin{array}{l}\text { Year beginning } \\
\text { * must correspond with } 2.3 \\
\text { Year ending }\end{array}$ & \\
\hline \multirow[t]{14}{*}{2.12} & $\begin{array}{l}\text { Data gathered from: } \\
\text { OSC database } \quad 1 \\
\text { Data collectors compiled it } 2 \\
\end{array}$ & & \\
\hline & Total number of clients & & \\
\hline & Total number female & & \\
\hline & Total number under age 10 & & \\
\hline & Total number under age 16 & & \\
\hline & Total number receiving HIV test & & \\
\hline & Total number receiving HIV PEP & & \\
\hline & Total number receiving EC & & \\
\hline & Total number receiving paralegal services & & \\
\hline & Total number receiving counselling services & & \\
\hline & Total number receiving VSU services & & \\
\hline & $\begin{array}{l}\text { Total number spending at least } 1 \text { night in safe } \\
\text { house }\end{array}$ & & \\
\hline & Total number returning for at least 1 follow-up visit & & \\
\hline & Total number with at least 1 court hearing & & \\
\hline
\end{tabular}




\begin{tabular}{|c|c|c|c|c|c|c|c|c|c|}
\hline \multicolumn{10}{|c|}{ STAFFING } \\
\hline $\begin{array}{l}2.13 \text { As of December } \\
2010, \text { what staff were } \\
\text { available at the OSC? } \\
\text { (write names for } \\
\text { each staff below) }\end{array}$ & $\begin{array}{c}0=\text { not at OSC } \\
1=\text { Full time at } \\
\text { OSC } \\
2=\text { on-call from } \\
\text { another location/ } \\
\text { organization }\end{array}$ & $\begin{array}{l}\text { Days available } \\
\text { (M-Su) }\end{array}$ & $\begin{array}{c}\text { Hours } \\
\text { worked } \\
\text { per } \\
\text { week }\end{array}$ & $\begin{array}{c}\text { Trained in GBV } \\
\text { management? } \\
\qquad(\mathrm{Y} / \mathrm{N})\end{array}$ & $\begin{array}{l}\text { Gross } \\
\text { monthly } \\
\text { salary } \\
\text { (Ksh) }\end{array}$ & $\begin{array}{l}\text { Salary } \\
\text { paid by } \\
\text { the } \\
\text { OSC? } \\
(\mathrm{Y} / \mathrm{N})\end{array}$ & $\begin{array}{l}\text { Additional } \\
\text { allowances } \\
\text { (list } \\
\text { individually) }\end{array}$ & $\begin{array}{l}\text { Allowance } \\
\text { s paid by } \\
\text { the OSC? }\end{array}$ & $\begin{array}{c}\text { Still working } \\
\text { with OSC } \\
\text { today? }\end{array}$ \\
\hline $\begin{array}{l}\text { Obstetrician/ } \\
\text { gynaecologist }\end{array}$ & Total number & & & & & & & & \\
\hline \multicolumn{10}{|l|}{1.} \\
\hline Pediatrician & Total number & & & & & & & & \\
\hline \multicolumn{10}{|l|}{1.} \\
\hline General practitioner & Total number & & & & & & & & \\
\hline \multicolumn{10}{|l|}{1.} \\
\hline \multicolumn{10}{|l|}{2.} \\
\hline Clinical officer & Total number & & & & & & & & \\
\hline \multicolumn{10}{|l|}{1.} \\
\hline \multicolumn{10}{|l|}{2.} \\
\hline Nurse/ Midwife & Total number & & & & & & & & \\
\hline \multicolumn{10}{|l|}{1.} \\
\hline \multicolumn{10}{|l|}{2.} \\
\hline 3. & & & & & & & & & \\
\hline
\end{tabular}




\begin{tabular}{|c|c|c|c|c|c|c|c|c|c|}
\hline $\begin{array}{l}2.13 \text { As of December } \\
2010, \text { what staff } \\
\text { were available at the } \\
\text { OSC? } \\
\text { (write names for } \\
\text { each staff below) }\end{array}$ & $\begin{array}{c}0=\text { not at OSC } \\
1=\text { Full time at } \\
\text { OSC } \\
2=\text { on-call from } \\
\text { another location/ } \\
\text { organization }\end{array}$ & $\begin{array}{l}\text { Days available } \\
\text { (M-Su) }\end{array}$ & $\begin{array}{l}\text { Hours } \\
\text { worked } \\
\text { per } \\
\text { week }\end{array}$ & $\begin{array}{c}\text { Trained in } \\
\text { GBV } \\
\text { management } \\
?(\mathrm{Y} / \mathrm{N})\end{array}$ & $\begin{array}{l}\text { Gross } \\
\text { monthly } \\
\text { salary } \\
(\text { ZMK })\end{array}$ & $\begin{array}{l}\text { Salary } \\
\text { paid by } \\
\text { the } \\
\text { OSC? } \\
(\mathrm{Y} / \mathrm{N})\end{array}$ & $\begin{array}{c}\text { Additional } \\
\text { allowances } \\
\text { (list } \\
\text { individually) }\end{array}$ & $\begin{array}{c}\text { Allowances } \\
\text { paid by the } \\
\text { OSC? }\end{array}$ & $\begin{array}{l}\text { Still working } \\
\text { with OSC today? }\end{array}$ \\
\hline $\begin{array}{l}\text { Professional } \\
\text { counsellor }\end{array}$ & Total number & & & & & & & & Total number \\
\hline \multicolumn{10}{|l|}{1.} \\
\hline \multicolumn{10}{|l|}{2.} \\
\hline & & & & & & & & & \\
\hline VSU officer & Total number & & & & & & & & Total number \\
\hline \multicolumn{10}{|l|}{1.} \\
\hline \multicolumn{10}{|l|}{2.} \\
\hline Paralegal & Total number & & & & & & & & Total number \\
\hline \multicolumn{10}{|l|}{1.} \\
\hline \multicolumn{10}{|l|}{2.} \\
\hline Site manager & Total number & & & & & & & & Total number \\
\hline \multicolumn{10}{|l|}{1.} \\
\hline 2. & & & & & & & & & \\
\hline
\end{tabular}




\begin{tabular}{|c|c|c|c|c|c|c|c|c|c|}
\hline $\begin{array}{l}2.13 \text { As of December } \\
2010, \text { what staff } \\
\text { were available at the } \\
\text { OSC? } \\
\text { (write names for } \\
\text { each staff below) }\end{array}$ & $\begin{array}{c}0=\text { not at OSC } \\
1=\text { Full time at } \\
\text { OSC } \\
2=\text { on-call from } \\
\text { another location/ } \\
\text { organization }\end{array}$ & $\begin{array}{c}\text { Days available } \\
\text { (M-Su) }\end{array}$ & $\begin{array}{l}\text { Hours } \\
\text { worked } \\
\text { per } \\
\text { week }\end{array}$ & $\begin{array}{c}\text { Trained in } \\
\text { GBV } \\
\text { management } \\
?(\mathrm{Y} / \mathrm{N})\end{array}$ & $\begin{array}{l}\text { Gross } \\
\text { monthly } \\
\text { salary } \\
\text { (Ksh) }\end{array}$ & $\begin{array}{l}\text { Salary } \\
\text { paid by } \\
\text { the } \\
\text { OSC? } \\
(\mathrm{Y} / \mathrm{N})\end{array}$ & $\begin{array}{l}\text { Additional } \\
\text { allowances } \\
\text { (list } \\
\text { individually) }\end{array}$ & $\begin{array}{c}\text { Allowances } \\
\text { paid by the } \\
\text { OSC? }\end{array}$ & $\begin{array}{l}\text { Working with } \\
\text { OSC today? }\end{array}$ \\
\hline \multicolumn{3}{|c|}{$\begin{array}{l}\text { Administrative/ management support } \\
\text { Total number }\end{array}$} & & & & & & & Total number \\
\hline \multicolumn{10}{|l|}{1.} \\
\hline \multicolumn{10}{|l|}{2.} \\
\hline Driver & Total number & & & & & & & & Total number \\
\hline \multicolumn{10}{|l|}{1.} \\
\hline \multicolumn{10}{|l|}{2.} \\
\hline Other (specify) & Total number & & & & & & & & Total number \\
\hline 1. & & & & & & & & & \\
\hline
\end{tabular}




\begin{tabular}{|c|c|c|c|c|c|}
\hline \multicolumn{2}{|c|}{$\begin{array}{l}2.13 \text { As of December 2010, what services were } \\
\text { provided at the OSC? }\end{array}$} & \multirow[t]{2}{*}{$\begin{array}{l}\text { Provided at OSC? } \\
\text { Write YES or NO }\end{array}$} & \multirow[t]{2}{*}{$\begin{array}{l}\text { Protocol is to provide } \\
\text { at OSC during first visit } \\
\text { Write YES or NO }\end{array}$} & \multirow[t]{2}{*}{$\begin{array}{l}\text { Protocol is to provide at } \\
\text { OSC during follow-up visit } \\
\text { Write YES or NO }\end{array}$} & \multirow[t]{2}{*}{$\begin{array}{l}\text { Referred for service } \\
\text { (write name of where } \\
\text { referred to) }\end{array}$} \\
\hline Clinical services & HIV counselling and testing & & & & \\
\hline & Provision of PEP (adult) & & & & \\
\hline & Provision of PEP (paediatric) & & & & \\
\hline & Pregnancy testing & & & & \\
\hline & Provision of EC & & & & \\
\hline & Treatment of physical injuries & & & & \\
\hline & Forensic examination (adult) & & & & \\
\hline & $\begin{array}{l}\begin{array}{l}\text { Forensic examination } \\
\text { (paediatric) }\end{array} \\
\end{array}$ & & & & \\
\hline & $\begin{array}{l}\text { Signing of the police medical } \\
\text { report form }\end{array}$ & & & & \\
\hline & Other: & & & & \\
\hline & Other: & & & & \\
\hline \multirow[t]{7}{*}{ Police } & Statement-taking from survivor & & & & \\
\hline & Statement-taking from others & & & & \\
\hline & Collection of forensic evidence & & & & \\
\hline & Storage of forensic evidence & & & & \\
\hline & $\begin{array}{l}\text { Issuing the police medical report } \\
\text { form }\end{array}$ & & & & \\
\hline & Other: & & & & \\
\hline & Opening a docket & & & & \\
\hline \multirow[t]{3}{*}{ Paralegal } & Legal advice provided & & & & \\
\hline & Court preparation provided & & & & \\
\hline & Other: & & & & \\
\hline \multirow{4}{*}{$\begin{array}{l}\text { Psychosocial } \\
\text { support }\end{array}$} & Trauma counselling provided & & & & \\
\hline & Safe house available & & & & \\
\hline & $\begin{array}{l}\text { Survivors groups that meet } \\
\text { regularly }\end{array}$ & & & & \\
\hline & $\begin{array}{l}\text { Community outreach conducted } \\
\text { by OSC staff }\end{array}$ & & & & \\
\hline
\end{tabular}




\begin{tabular}{|c|c|c|c|}
\hline & & $\begin{array}{l}\text { First } 12 \text { months of operation } \\
\text { (2006 or 2008) }\end{array}$ & 2010 \\
\hline \multirow[t]{7}{*}{2.14} & $\begin{array}{l}\text { Did you conduct any outreach activities? } \\
\text { (if yes, ask a--f) } \\
\text { (If no, skip section) }\end{array}$ & - Write YES or NO & \\
\hline & a. Community meetings (stakeholder or caregiver) & & \\
\hline & $\begin{array}{l}\text { b. Sensitization for other service providers } \\
\text { (police/health care, etc) }\end{array}$ & & \\
\hline & c. Survivors' groups & & \\
\hline & d. Men's network & & \\
\hline & e. Schools outreach & & \\
\hline & f. Other (specify ___ & & \\
\hline \multirow[t]{11}{*}{2.15} & Tell me about the COMMUNITY MEETINGS & $\bullet$ & \\
\hline & Approximately how many were held each year? & - __ number/year & __ number/year \\
\hline & Approximately how many people attend each meeting? & - _ number or participants & _ number or participants \\
\hline & Cost of materials produced for meetings & - & \\
\hline & Media costs (radio, TV, newspaper) & $\bullet$ & \\
\hline & Teas/ lunch/ refreshments & $\bullet$ & \\
\hline & Venue hire & $\bullet$ & \\
\hline & Per diems/ allowances for participants & $\bullet$ & \\
\hline & Per diems/ allowances for staff & $\bullet$ & \\
\hline & Transportation allowances for staff & - & \\
\hline & $\begin{array}{l}\text { Number of days a month dedicated to planning and } \\
\text { conducting community outreach activities } \\
\text { Staff member } 1 \text { position: } \\
\text { Staff member } 2 \text { position: } \\
\text { Staff member } 3 \text { position: }\end{array}$ & $\begin{array}{l}\text { 1: days a month } \\
\text { 2: days a month } \\
\text { 3: days a month }\end{array}$ & $\begin{array}{l}\text { 1: days a month } \\
\text { 2: days a month } \\
\text { 3: days a month }\end{array}$ \\
\hline
\end{tabular}




\begin{tabular}{|c|c|c|c|}
\hline & & $\begin{array}{l}\text { Expenditures in first } 12 \text { months of } \\
\text { operation }\end{array}$ & Expenditures in last 12 months under study \\
\hline \multirow[t]{11}{*}{2.16} & $\begin{array}{l}\text { Tell me about the SENSITIZATIONS FOR OTHER } \\
\text { SERVICE PROVIDERS }\end{array}$ & $\bullet$ & \\
\hline & Approximately how many were held each year? & - __ number/year & __ number/year \\
\hline & $\begin{array}{l}\text { Approximately how many people attend each } \\
\text { meeting? }\end{array}$ & - _ number or participants & __ number or participants \\
\hline & Cost of materials produced for meetings & $\bullet$ & \\
\hline & Media costs (radio, TV, newspaper) & $\bullet$ & \\
\hline & Teas/ lunch/ refreshments & $\bullet$ & \\
\hline & Venue hire & $\bullet$ & \\
\hline & Per diems/ allowances for participants & $\bullet$ & \\
\hline & Per diems/ allowances for staff & $\bullet$ & \\
\hline & Transportation allowances for staff & $\bullet$ & \\
\hline & $\begin{array}{l}\text { Number of days a month dedicated to planning } \\
\text { and conducting community outreach activities } \\
\text { Staff member } 1 \text { position: } \\
\text { Staff member } 2 \text { position: } \\
\text { Staff member } 3 \text { position: }\end{array}$ & $\begin{array}{l}\text { 1: days a month } \\
\text { 2: days a month } \\
\text { 3: days a month }\end{array}$ & $\begin{array}{l}\text { 1: days a month } \\
\text { 2: days a month } \\
\text { 3: days a month }\end{array}$ \\
\hline \multirow[t]{10}{*}{2.17} & Tell me about the SURVIVORS GROUPS & $\bullet$ & \\
\hline & Approximately how many were held each year? & - __ number/year & ___ number/year \\
\hline & $\begin{array}{l}\text { Approximately how many people attend each } \\
\text { meeting? }\end{array}$ & - $\quad$ number or participants & __ number or participants \\
\hline & Cost of materials produced for meetings & $\bullet$ & \\
\hline & Media costs (radio, TV, newspaper) & $\bullet$ & \\
\hline & Teas/ lunch/ refreshments & $\bullet$ & \\
\hline & Venue hire & $\bullet$ & \\
\hline & Per diems/ allowances for participants & $\bullet$ & \\
\hline & Per diems/ allowances for staff & $\bullet$ & \\
\hline & Transportation allowances for staff & $\bullet$ & \\
\hline
\end{tabular}




\begin{tabular}{|c|c|c|c|}
\hline & & $\begin{array}{l}\text { First } 12 \text { months of operation (2006 } \\
\text { or 2008) }\end{array}$ & 2010 \\
\hline & $\begin{array}{l}\text { Number of days a month dedicated to planning } \\
\text { and conducting community outreach activities } \\
\text { Staff member } 1 \text { position: } \\
\text { Staff member } 2 \text { position: } \\
\text { Staff member } 3 \text { position: }\end{array}$ & $\begin{array}{l}\text { 1: days a month } \\
\text { 2: days a month } \\
\text { 3: days a month }\end{array}$ & $\begin{array}{l}\text { 1: days a month } \\
\text { 2: days a month } \\
\text { 3: days a month }\end{array}$ \\
\hline \multirow[t]{11}{*}{2.18} & Tell me about the MEN'S NETWORKS & $\bullet$ & \\
\hline & Approximately how many were held each year? & - __ number/year & ___ number/year \\
\hline & $\begin{array}{l}\text { Approximately how many people attend each } \\
\text { meeting? }\end{array}$ & - $\quad$ number or participants & ___ number or participants \\
\hline & Cost of materials produced for meetings & $\bullet$ & \\
\hline & Media costs (radio, TV, newspaper) & - & \\
\hline & Teas/ lunch/ refreshments & - & \\
\hline & Venue hire & $\bullet$ & \\
\hline & Per diems/ allowances for participants & - & \\
\hline & Per diems/ allowances for staff & $\bullet$ & \\
\hline & Transportation allowances for staff & $\bullet$ & \\
\hline & $\begin{array}{l}\text { Number of days a month dedicated to planning } \\
\text { and conducting community outreach activitieaff } \\
\text { member } 1 \text { position: } \\
\text { Staff member } 2 \text { position: } \\
\text { Staff member } 3 \text { position: }\end{array}$ & $\begin{array}{l}\text { 1: days a month } \\
\text { 2: days a month } \\
\text { 3: days a month }\end{array}$ & $\begin{array}{l}\text { 1: days a month } \\
\text { 2: days a month } \\
\text { 3: days a month }\end{array}$ \\
\hline \multirow[t]{6}{*}{2.19} & Tell me about the SCHOOLS OUTREACHES & $\bullet$ & \\
\hline & Approximately how many were held each year? & - _ number/year & __ number/year \\
\hline & $\begin{array}{l}\text { Approximately how many people attend each } \\
\text { meeting? }\end{array}$ & - $\quad$ number or participants & __ number or participants \\
\hline & Cost of materials produced for meetings & $\bullet$ & \\
\hline & Media costs (radio, TV, newspaper) & - & \\
\hline & Teas/ lunch/ refreshments & $\bullet$ & \\
\hline
\end{tabular}




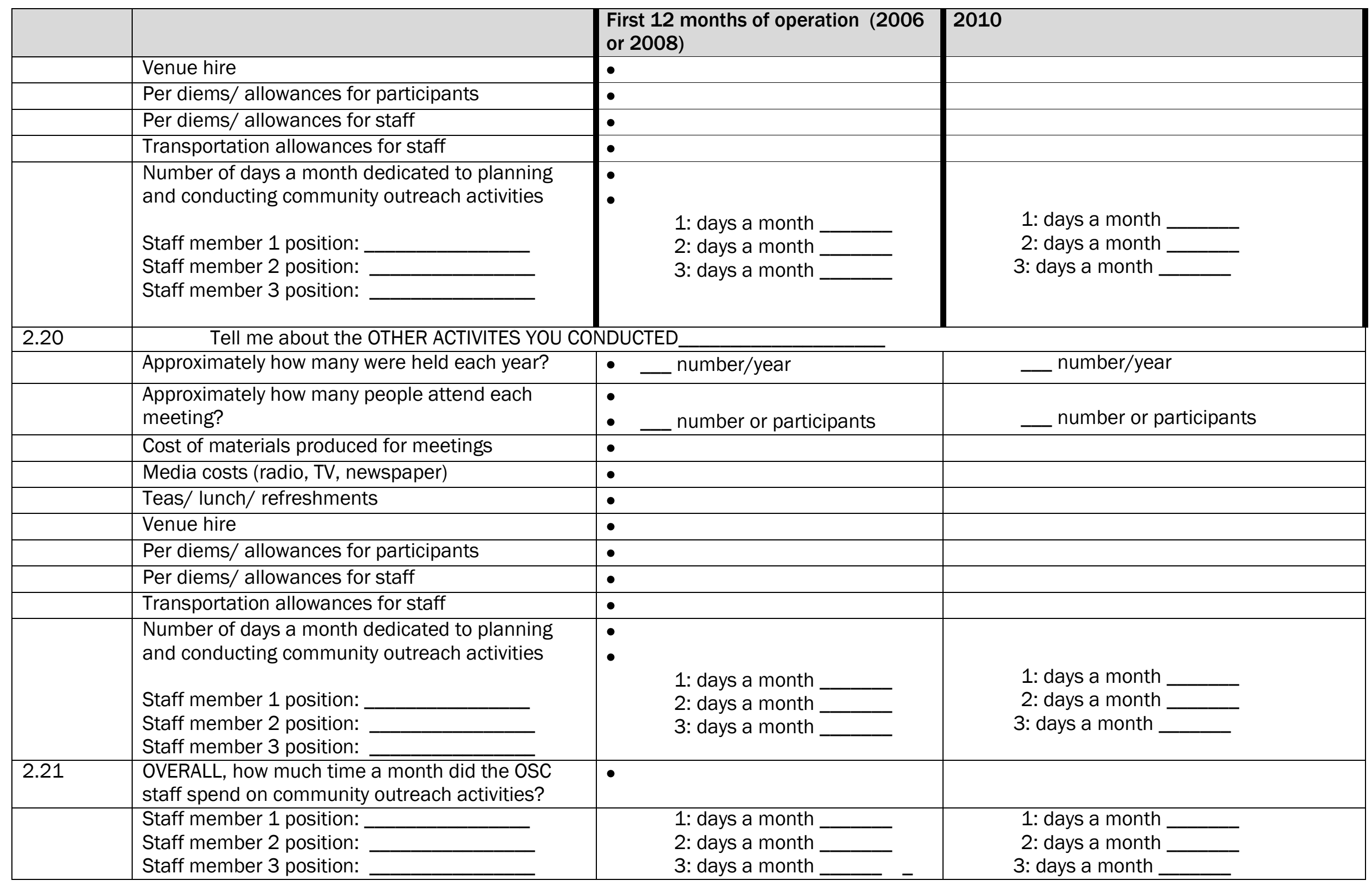




\begin{tabular}{|c|c|c|c|c|c|c|c|c|}
\hline \multicolumn{9}{|c|}{ Section 3: Training costs } \\
\hline 3.1 & $\begin{array}{l}\text { Total number of trainings THAT OSC } \\
\text { PARTCIIPATED IN }\end{array}$ & \multicolumn{3}{|c|}{$\begin{array}{l}\text { Total number in first } 12 \text { months of } \\
\text { operation }\end{array}$} & \multicolumn{4}{|c|}{ Total number in 12 months under study } \\
\hline \multicolumn{9}{|c|}{ Complete the following for each training } \\
\hline & & Training 1 & Training 2 & Training 3 & Training 4 & Training 5 & Training 6 & Training 7 \\
\hline 3.2 & Month and year of training & $\overline{(\mathrm{MM} / \mathrm{YY})}$ & $\overline{(\mathrm{MM} / \mathrm{YY})}$ & $\overline{(\mathrm{MM}} / \overline{\mathrm{YY})}$ & $\overline{(\mathrm{MM} / \mathrm{YY})}$ & $\overline{(\mathrm{MM} / \mathrm{YY})}$ & $\overline{(\mathrm{MM} / \mathrm{YY})}$ & $\overline{(\mathrm{MM} / \mathrm{YY})}$ \\
\hline \multirow[t]{2}{*}{3.3} & $\begin{array}{l}\text { Within first } 12 \text { months of operation (2006 or } \\
\text { 2008) } \\
\text { Within } 2101 \ldots . . .1\end{array}$ & & & & & & & \\
\hline & How many days was the training? & __ days & ___days & ___days & __ days & ___days & _ days & _ days \\
\hline 3.4 & Total number of staff trained & ___people & _people & _ people & ___people & __people & people & people \\
\hline 3.5 & 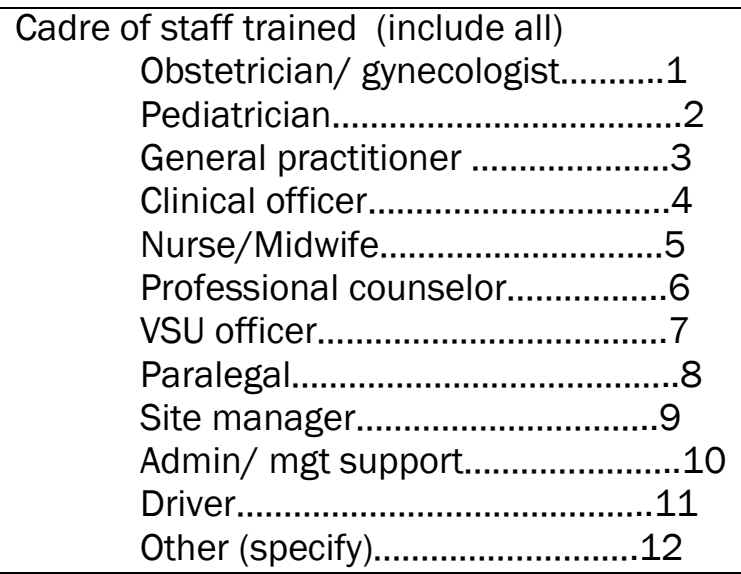 & & & & & & & \\
\hline
\end{tabular}




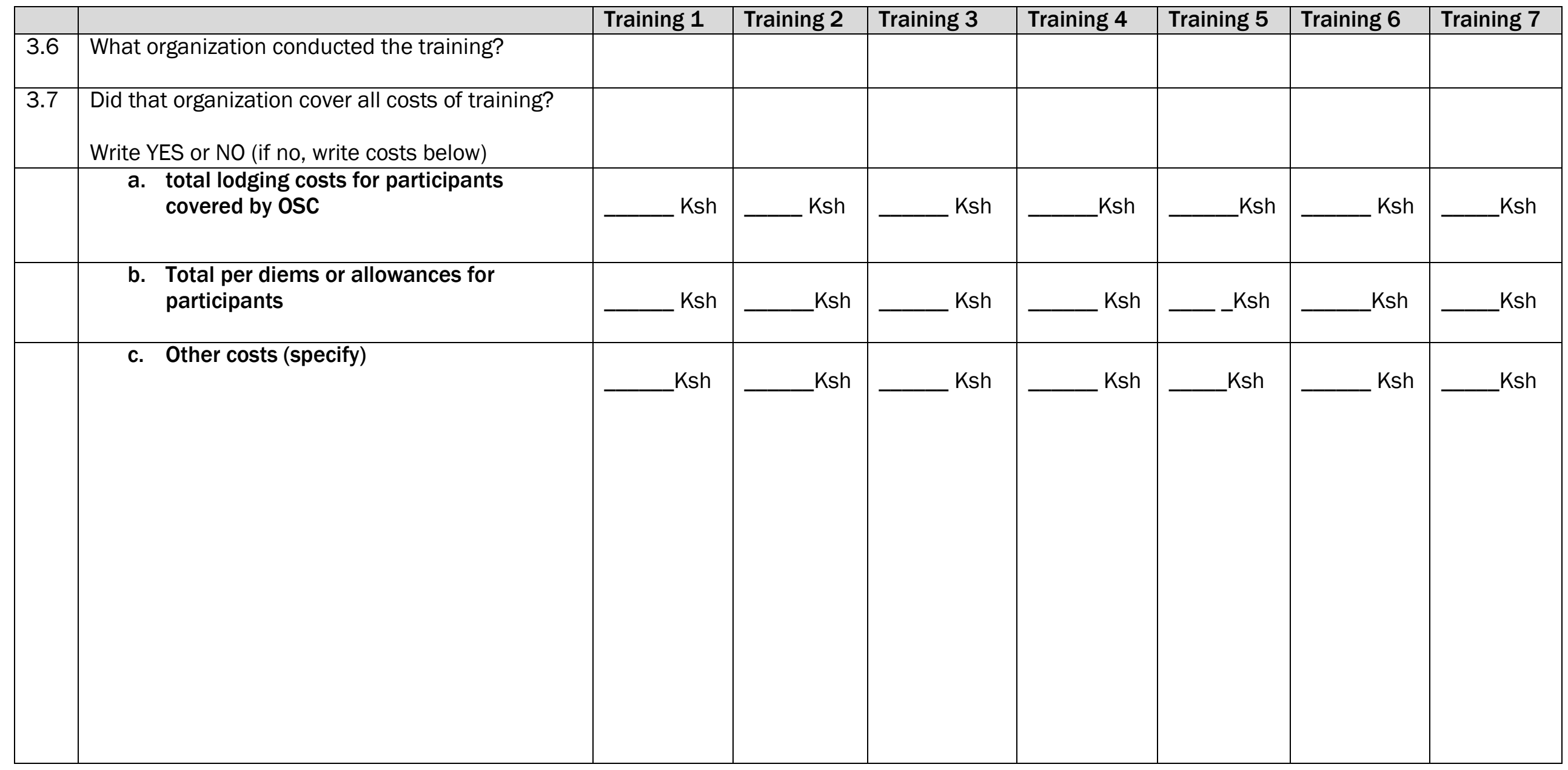




\begin{tabular}{|c|c|c|c|c|c|c|c|c|c|}
\hline & \multicolumn{9}{|c|}{$\begin{array}{l}\text { Section 4: General infrastructure } \\
\text { Now get up and move around. This section requires the data collector to physically verify the existence of these services/facilities. }\end{array}$} \\
\hline & & Room 1 & Room 2 & Room 3 & Room 4 & Room 5 & Room 6 & Room 7 & Room 8 \\
\hline 4.1 & $\begin{array}{l}\text { In total, how many rooms does the } \\
\text { OSC have? (include all client/admin } \\
\text { rooms, kitchens, showers, toilets) }\end{array}$ & \multirow{2}{*}{\multicolumn{8}{|c|}{ Total number of rooms }} \\
\hline & a. Is there a kitchen? $\mathrm{Y} / \mathrm{N}$ & & & & & & & & \\
\hline & b. Number of toilets & \multicolumn{8}{|c|}{ Do the staff and survivors use the same toilet? $\mathrm{Y} / \mathrm{N}$} \\
\hline & $\begin{array}{l}\text { c. Is there a shower for survivors } \\
\text { to use? }\end{array}$ & \multicolumn{8}{|c|}{ Are there towels? $\mathrm{Y} / \mathrm{N}$} \\
\hline & $\begin{array}{l}\text { d. How many of these rooms are } \\
\text { used for client/admin } \\
\text { services? }\end{array}$ & \multicolumn{8}{|c|}{$\begin{array}{l}\text { Total number of rooms used for client/admin services__ } \\
\text { (Should be total number of rooms minus toilets and kitchens. If not, write explanatory note) }\end{array}$} \\
\hline 4.2 & $\begin{array}{l}\text { What is the name/designation for } \\
\text { each of the rooms where client/admin } \\
\text { services are provided? ALL } \\
\text { QUESTIONS BELOW PERTAIN TO THE } \\
\text { ROOMS INDICATED HERE }\end{array}$ & & & & & & & & \\
\hline 4.3 & $\begin{array}{l}\text { What services are provided in each } \\
\text { room? (multiple responses allowed) } \\
1=\text { reception } \\
2=\text { client waiting area } \\
3=\text { medical services room } \\
4=\text { counselling } \\
5=\text { Police (VSU) services } \\
6=\text { Paralegal services } \\
7=\text { store room } \\
8=\text { administrative office } \\
9=\text { other (specify) }\end{array}$ & & & & & & & & \\
\hline 4.4 & $\begin{array}{l}\text { Dimension of each room (in square } \\
\text { meters) }\end{array}$ & & & & & & & & \\
\hline
\end{tabular}




\begin{tabular}{|c|c|c|c|c|c|c|c|c|c|}
\hline & & Room 1 & Room 2 & Room 3 & Room 4 & Room 5 & Room 6 & Room 7 & Room 8 \\
\hline 4.5 & $\begin{array}{c}\text { Does this room have a door? } \\
\text { Write YES or NO }\end{array}$ & & & & & & & & \\
\hline 4.6 & $\begin{array}{l}\text { Can conversations be heard from the } \\
\text { outside? } \\
\quad \text { Write YES or NO }\end{array}$ & & & & & & & & \\
\hline 4.7 & $\begin{array}{l}\text { Can clients be seen from the outside? } \\
\text { Write YES or NO }\end{array}$ & & & & & & & & \\
\hline 4.8 & $\begin{array}{l}\text { Is this room unlocked at all times the } \\
\text { OSC is open? } \\
\text { Write YES or NO }\end{array}$ & & & & & & & & \\
\hline 4.9 & $\begin{array}{l}\text { Is this room used for any other } \\
\text { purposes? } \\
\text { Write YES (SPECIFY) or NO }\end{array}$ & & & & & & & & \\
\hline 4.10 & $\begin{array}{l}\text { Was this room renovated during the } \\
\text { first } 12 \text { months of the OSCs } \\
\text { operation? ( } 2006 \text { or } 2008) \\
\text { Write YES (specify) or NO }\end{array}$ & & & & & & & & \\
\hline 4.11 & $\begin{array}{l}\text { Total amount spent renovating the OSC } \\
\text { Indicate TOTAL amount in KSh }\end{array}$ & during the & rst $12 \mathrm{mc}$ & s of opera & n $(2006$ & 08) (for al & ooms) & & \\
\hline 4.12 & $\begin{array}{l}\text { What were the costs of renovating } \\
\text { each room during the first } 12 \text { months } \\
\text { of operation (2006 or 2008)? } \\
\text { Indicate amount spent per room in } \\
\text { Ksh (should equal total in } 3.8 a \text { ) }\end{array}$ & & & & & & & & \\
\hline 4.13 & $\begin{array}{l}\text { Total amount spent maintaining and/o } \\
\text { Indicate TOTAL amount in Ksh }\end{array}$ & repairing $t$ & OSC du & 2010 (for & rooms) & & & & \\
\hline 4.14 & $\begin{array}{l}\text { What were the costs of renovating } \\
\text { each room during } 2010 ? \\
\text { Indicate amount spent per room in } \\
\text { Ksh (should equal total }\end{array}$ & & & & & & & & \\
\hline
\end{tabular}




\begin{tabular}{|c|c|c|c|}
\hline \multicolumn{4}{|c|}{$\begin{array}{l}\text { This section requires the data collector to physically verify the existence of these services/facilities } \\
\text { within the rooms of the OSC. }\end{array}$} \\
\hline & & & $\begin{array}{l}\text { Indicate room \#where } \\
\text { found (see sect. 3) }\end{array}$ \\
\hline \multicolumn{4}{|c|}{ If medical services are not provided, skip to question 4.13} \\
\hline 5.1 & $\begin{array}{l}\text { Is there an examination } \\
\text { couch? }\end{array}$ & 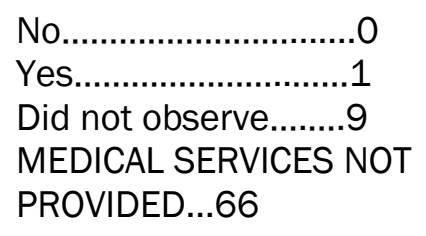 & \\
\hline 5.2 & $\begin{array}{l}\text { Is there a working angle } \\
\text { lamp? }\end{array}$ & $\begin{array}{l}\text { No................................ } \\
\text { Yes.......................... } \\
\text { Did not observe.......9 } \\
\text { MEDICAL SERVICES NOT } \\
\text { PROVIDED...66 }\end{array}$ & \\
\hline 5.3 & Is there a speculum? & $\begin{array}{l}\text { No............................ } \\
\text { Yes.......................... } \\
\text { Did not observe.......9 } \\
\text { MEDICAL SERVICES NOT } \\
\text { PROVIDED...66 }\end{array}$ & \\
\hline 5.4 & $\begin{array}{l}\text { Are there examination } \\
\text { gloves? }\end{array}$ & 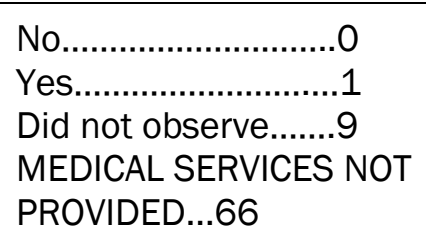 & \\
\hline 5.5 & $\begin{array}{l}\text { Is there a sharps } \\
\text { container? }\end{array}$ & 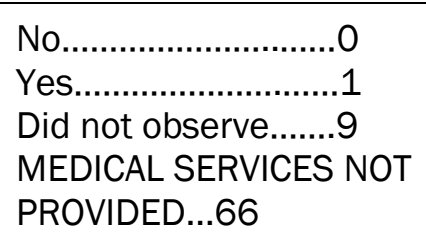 & \\
\hline 5.6 & $\begin{array}{l}\text { Is there a lockable medical } \\
\text { supply cabinet? }\end{array}$ & $\begin{array}{l}\text { No................................. } \\
\text { Yes........................ } \\
\text { Did not observe......9 } \\
\text { MEDICAL SERVICES NOT } \\
\text { PROVIDED...66 }\end{array}$ & \\
\hline 5.7 & Are there swabs? & $\begin{array}{l}\text { No................................. } \\
\text { Yes........................ } \\
\text { Did not observe.......9 }\end{array}$ & \\
\hline 5.8 & Are there blood tubes? & $\begin{array}{l}\text { No............................... } \\
\text { Yes........................ } \\
\text { Did not observe.......9 }\end{array}$ & \\
\hline
\end{tabular}




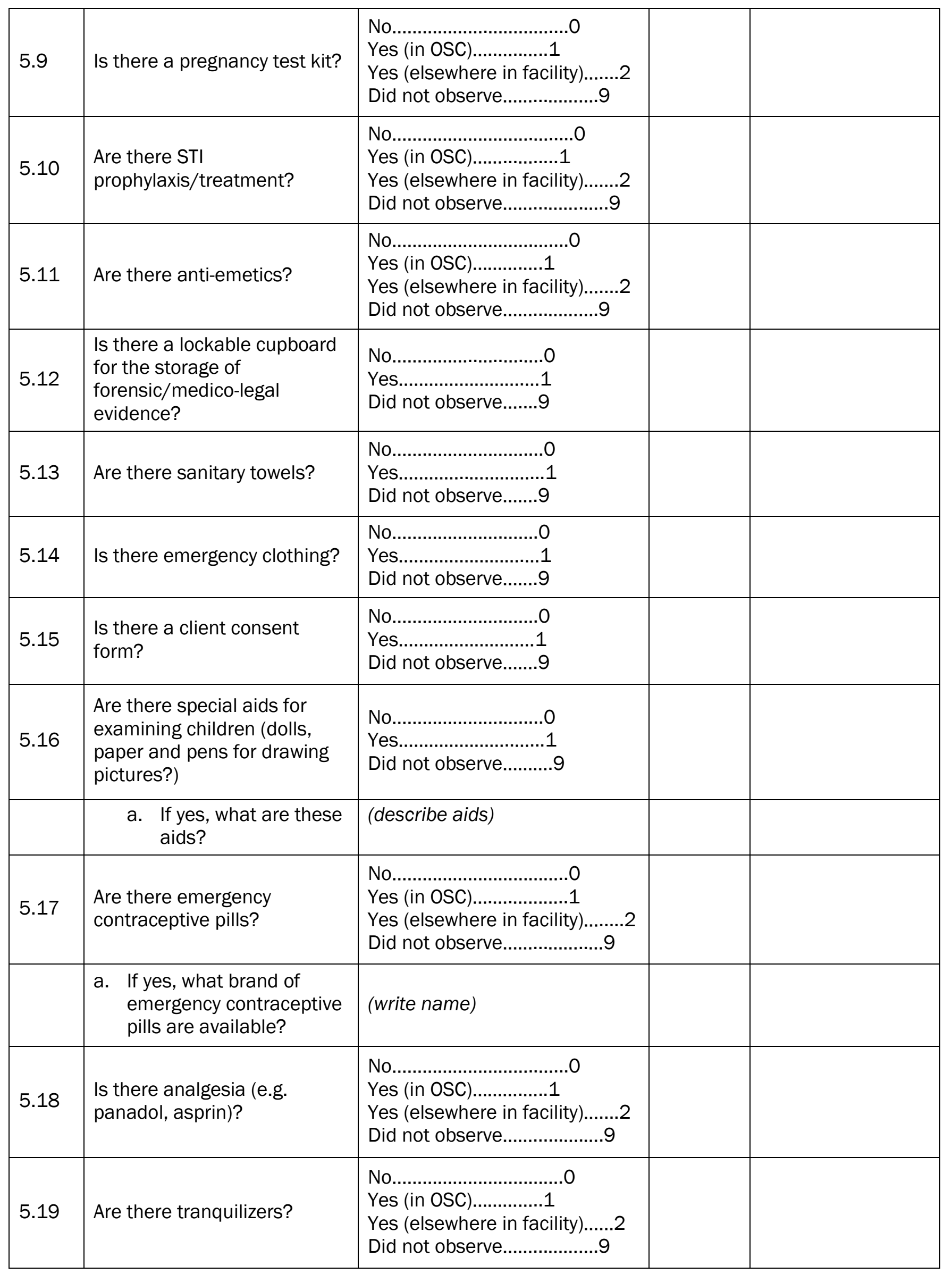




\begin{tabular}{|c|c|c|c|}
\hline \multicolumn{3}{|c|}{ HIV Services } & \\
\hline 5.20 & $\begin{array}{l}\text { Is there a HIV rapid test kit in } \\
\text { the OSC? }\end{array}$ & 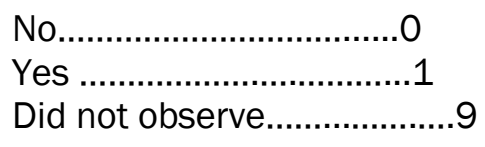 & \\
\hline 5.21 & $\begin{array}{l}\text { Are there post-exposure } \\
\text { prophylaxis (PEP) drugs to } \\
\text { prevent HIV? }\end{array}$ & 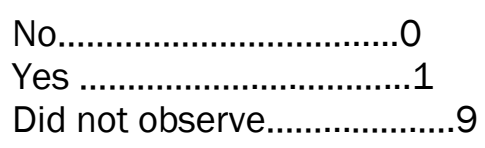 & \\
\hline 5.22 & $\begin{array}{l}\text { How many days of PEP drugs } \\
\text { are provided during initial } \\
\text { visit? }\end{array}$ & $\begin{array}{l}3 \text { days of pills.................. } \\
28 \text { days of pills.................2 } \\
\text { Other }\end{array}$ & $\mathrm{n} / \mathrm{a}$ \\
\hline 5.23 & $\begin{array}{l}\text { When are PEP clients advised } \\
\text { to return to the facility for a } \\
\text { follow-up HIV test? }\end{array}$ & ___ weeks & $\mathrm{n} / \mathrm{a}$ \\
\hline
\end{tabular}

\begin{tabular}{|c|c|c|c|}
\hline $\begin{array}{l}\text { Sect } \\
\text { This } \\
\text { whe } \\
\text { NOT } \\
\text { FOU }\end{array}$ & $\begin{array}{l}\text { 6: Referrals and guidelines } \\
\text { ction requires the data collector to physic } \\
\text { services are provided. } \\
\text { FIRST LOOK FOR GUIDELINES IN THE ROO } \\
\text { THERE, THEN LOOK FOR GUIDELINES IN }\end{array}$ & $\begin{array}{l}\text { ally verify the existence of } t \\
\text { US/AREAS WHERE SERIVICE } \\
\text { HE ADMINSITRATION ROON }\end{array}$ & $\begin{array}{l}\text { s in the room } \\
\text { ED. IF NOT }\end{array}$ \\
\hline & & & $\begin{array}{l}\text { Indicate room } \\
\text { \#where found } \\
\text { (see sect. 3) }\end{array}$ \\
\hline 6.1 & $\begin{array}{l}\text { Do OSC records clearly indicate if a } \\
\text { survivor presents for GBV services? }\end{array}$ & 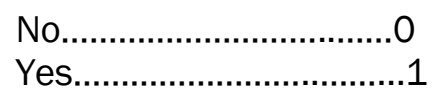 & \\
\hline 6.2 & $\begin{array}{l}\text { Do OSC records indicate if a client } \\
\text { receives follow-up care? }\end{array}$ & No.................................... & \\
\hline 6.3 & $\begin{array}{l}\text { Does the OSC have written guidelines or } \\
\text { protocols for the clinical management of } \\
\text { GBV? }\end{array}$ & No................................. & \\
\hline & $\begin{array}{l}\text { a. Are the clinical management } \\
\text { guidelines available in or nearby the } \\
\text { examination room? }\end{array}$ & 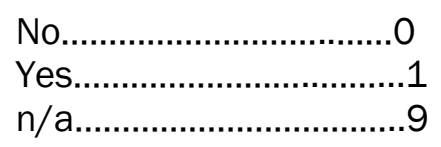 & \\
\hline & $\begin{array}{l}\text { b. Do they include special provisions } \\
\text { for examining and treating infants } \\
\text { and children? }\end{array}$ & 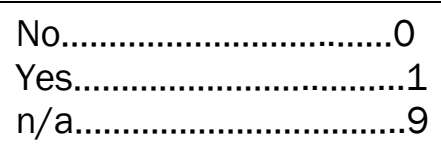 & \\
\hline 6.4 & $\begin{array}{l}\text { Does the OSC provide leaflets or } \\
\text { handouts for survivors? }\end{array}$ & 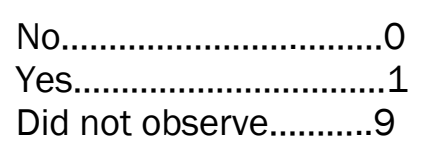 & \\
\hline & $\begin{array}{l}\text { Do these client materials address } \\
\text { medication provided for SV } \\
\text { survivors? }\end{array}$ & 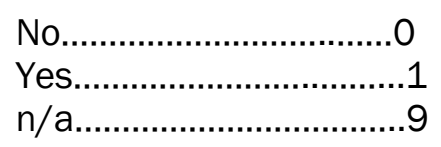 & \\
\hline
\end{tabular}




\begin{tabular}{|c|c|c|}
\hline & $\begin{array}{l}\text { b. Do these client materials address } \\
\text { support services for rape survivors, } \\
\text { such as NGOs? }\end{array}$ & 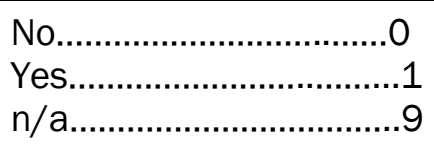 \\
\hline \multirow[t]{4}{*}{6.5} & $\begin{array}{l}\text { Does the OSC have written guidelines } \\
\text { for referral of survivors to other } \\
\text { services? }\end{array}$ & 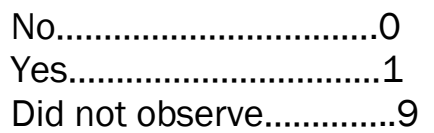 \\
\hline & $\begin{array}{l}\text { a. Do the referral guidelines include } \\
\text { phone numbers and contact people } \\
\text { at each referral point? }\end{array}$ & 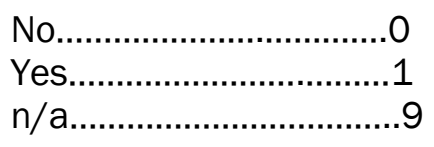 \\
\hline & $\begin{array}{l}\text { b. Do the referral guidelines explicitly } \\
\text { address procedures for removing a } \\
\text { child from an unsafe domestic } \\
\text { environment? }\end{array}$ & 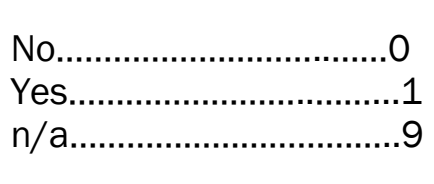 \\
\hline & $\begin{array}{l}\text { c. Do the referral guidelines explicitly } \\
\text { address procedures for removing an } \\
\text { adult from an unsafe domestic } \\
\text { environment? }\end{array}$ & 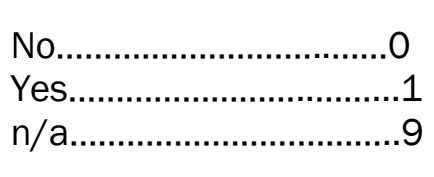 \\
\hline
\end{tabular}




\begin{tabular}{|c|c|c|c|c|c|c|c|}
\hline \multicolumn{8}{|c|}{$\begin{array}{l}\text { Section 7: Non-medical equipment purchased, start-up and ongoing } \\
\text { Ask the center manager or accountant first for this information. You } \\
\text { Fill in any blanks and verify with the organization funding the centre } \\
\text { Source of data (specify) }\end{array}$} \\
\hline & & \multicolumn{3}{|c|}{$\begin{array}{l}\text { Expenditures in first } 12 \text { months of operation } \\
\text { (2006 or } 2008)\end{array}$} & \multicolumn{3}{|c|}{ Expenditures in 2010} \\
\hline & & $\begin{array}{l}\text { Total number } \\
\text { purchased in } \\
\text { year }\end{array}$ & $\begin{array}{l}\text { Purchase } \\
\text { date (s) }\end{array}$ & $\begin{array}{l}\text { Total } \\
\text { purchase price } \\
\text { (indicate currency) }\end{array}$ & $\begin{array}{l}\text { Total number } \\
\text { purchased in } \\
\text { year }\end{array}$ & $\begin{array}{l}\text { Purchase } \\
\text { date }\end{array}$ & $\begin{array}{l}\text { Total purchase } \\
\text { price } \\
\text { (indicate currency) }\end{array}$ \\
\hline 7.1 & Office tables & & & & & & \\
\hline 7.2 & Office chairs & & & & & & \\
\hline 7.3 & Office cabinets & & & & & & \\
\hline 7.4 & Visitors chairs & & & & & & \\
\hline 7.5 & Office computers & & & & & & \\
\hline 7.6 & LCD projector & & & & & & \\
\hline 7.7 & Printers & & & & & & \\
\hline 7.8 & Photocopiers & & & & & & \\
\hline 7.9 & Telephones & & & & & & \\
\hline 7.10 & Fax machines & & & & & & \\
\hline 7.11 & Television sets & & & & & & \\
\hline 7.12 & Refrigerators & & & & & & \\
\hline 7.13 & Vehicle 1 (indicate make and model) & & & & & & \\
\hline 7.14 & Vehicle 2 (indicate make and model) & & & & & & \\
\hline 7.15 & Other (specify) & & & & & & \\
\hline 7.16 & Other (specify) & & & & & & \\
\hline
\end{tabular}




\begin{tabular}{|c|c|c|c|c|c|c|c|}
\hline \multicolumn{8}{|c|}{$\begin{array}{l}\text { Section 8: Medical equipment and supplies purchased, s } \\
\text { Does this center purchase any medical supplies for use in } \\
\text { If no, skip this section } \\
\text { Source of data (specify) }\end{array}$} \\
\hline & & \multicolumn{3}{|c|}{ 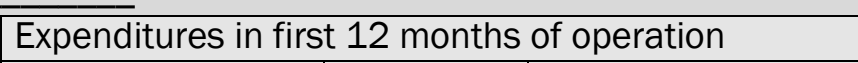 } & \multicolumn{3}{|c|}{ Expenditures in 12 months under study } \\
\hline & & $\begin{array}{l}\text { Total number } \\
\text { purchased in year }\end{array}$ & $\begin{array}{l}\text { Purchase } \\
\text { date (s) }\end{array}$ & \begin{tabular}{|l} 
Total \\
purchase price \\
(indicate currency)
\end{tabular} & $\begin{array}{l}\text { Total number } \\
\text { purchased in } \\
\text { year }\end{array}$ & $\begin{array}{l}\text { Purchase } \\
\text { date }\end{array}$ & $\begin{array}{l}\text { Total purchase } \\
\text { price } \\
\text { (indicate currency) }\end{array}$ \\
\hline \multirow[t]{14}{*}{8.1} & Examination items & & & & & & \\
\hline & Speculums & & & & & & \\
\hline & Receivers & & & & & & \\
\hline & Gallipots & & & & & & \\
\hline & Trays & & & & & & \\
\hline & Plastic medium sized bowls & & & & & & \\
\hline & $\begin{array}{l}\text { Draw sheets (Can be disposable in } \\
\text { which case no need for mackintosh) }\end{array}$ & & & & & & \\
\hline & Draw mackintosh & & & & & & \\
\hline & Examination couch & & & & & & \\
\hline & Examination angular lamp & & & & & & \\
\hline & Sanitary towels & & & & & & \\
\hline & Cotton wool balls & & & & & & \\
\hline & Gauze balls & & & & & & \\
\hline & Surgical gloves & & & & & & \\
\hline \multirow[t]{4}{*}{8.2} & Forensic evidence collection & & & & & & \\
\hline & Specimen tubes & & & & & & \\
\hline & Sterile urine containers & & & & & & \\
\hline & High Vaginal Swabs & & & & & & \\
\hline
\end{tabular}




\begin{tabular}{|c|c|c|c|c|c|}
\hline & $\begin{array}{l}\text { Expenditures in first } 12 \text { months of } \\
\text { operation }\end{array}$ & $\begin{array}{l}\text { Expenditures in } \\
12 \text { months under } \\
\text { study }\end{array}$ & $\begin{array}{l}\text { Expenditures in } \\
\text { first } 12 \text { months of } \\
\text { operation }\end{array}$ & $\begin{array}{l}\text { Expenditures } \\
\text { in } 12 \text { months } \\
\text { under study }\end{array}$ & $\begin{array}{l}\text { Expenditures in first } \\
12 \text { months of } \\
\text { operation }\end{array}$ \\
\hline & Ordinary swabs & & & & \\
\hline & Police medical report forms & & & & \\
\hline & Specimen tubes & & & & \\
\hline & $\begin{array}{l}\text { Wide sheets of paper for survivor to } \\
\text { stand on when removing clothes in } \\
\text { readiness for examination or during } \\
\text { up right examination }\end{array}$ & & & & \\
\hline & Paper bags & & & & \\
\hline & Lockable filing cabinets & & & & \\
\hline & Camera & & & & \\
\hline \multirow[t]{11}{*}{8.3} & Infection prevention & & & & \\
\hline & Plastic medium sized buckets & & & & \\
\hline & Mutton cloth & & & & \\
\hline & Gloves & & & & \\
\hline & Disposable gloves & & & & \\
\hline & Plastic pedal bins & & & & \\
\hline & Disposable bin liners & & & & \\
\hline & Sharps containers & & & & \\
\hline & Syringes and needles & & & & \\
\hline & Soap for hand washing & & & & \\
\hline & Paper towels & & & & \\
\hline \multirow[t]{6}{*}{8.4} & Treatment & & & & \\
\hline & STI Antibiotics & & & & \\
\hline & Hepatitis B Vaccine & & & & \\
\hline & Tetanus Toxoid & & & & \\
\hline & PEP ARVs for adults & & & & \\
\hline & PEP ARVs for children & & & & \\
\hline
\end{tabular}




\begin{tabular}{|l|l|}
\hline \multicolumn{2}{|l}{} \\
\hline & Emergency contraceptive pills \\
\hline & Analgesics for adults \\
\hline & Analgesics for children \\
\hline & Wound cleaning agents \\
\hline & Suturing materials \\
\hline & Bandages and splints \\
\hline & Syringes and needles \\
\hline 8.5 & Special equipment for children \\
\hline & Chairs for children \\
\hline & Anatomic dolls \\
\hline & Toys, games \\
\hline 8.6 & Stationery including pencils, crayons \\
\hline & Safe houses and social support \\
\hline & Beds \\
\hline & Tables for safe house \\
\hline & Linens \\
\hline & Changing clothes for adults and children \\
\hline & Soap and face towel \\
\hline & Food at shelter \\
\hline & $\begin{array}{l}\text { Cash transfers for maintenance of } \\
\text { survivors outside home }\end{array}$ \\
\hline & Educational support for relocated children \\
\hline & Food packs \\
\hline & Transportation reimbursement \\
\hline & Other material support (specify) \\
\hline & Other \\
\hline & \\
\hline &
\end{tabular}

\begin{tabular}{|c|c|c|c|c|c|}
\hline \multicolumn{3}{|c|}{ Expenditures in first 12 months of operation } & \multicolumn{3}{|c|}{ Expenditures in 12 months under study } \\
\hline $\begin{array}{l}\text { Total number } \\
\text { purchased in } \\
\text { year }\end{array}$ & $\begin{array}{l}\text { Purchase } \\
\text { date (s) }\end{array}$ & $\begin{array}{l}\text { Total } \\
\text { purchase price } \\
\text { (indicate currency) }\end{array}$ & $\begin{array}{l}\text { Total number } \\
\text { purchased in } \\
\text { year }\end{array}$ & $\begin{array}{l}\text { Purchas } \\
\text { e date }\end{array}$ & $\begin{array}{l}\text { Total purchase } \\
\text { price } \\
\text { (indicate currency) }\end{array}$ \\
\hline & & & & & \\
\hline & & & & & \\
\hline & & & & & \\
\hline & & & & & \\
\hline & & & & & \\
\hline & & & & & \\
\hline & & & & & \\
\hline & & & & & \\
\hline & & & & & \\
\hline & & & & & \\
\hline & & & & & \\
\hline & & & & & \\
\hline & & & & & \\
\hline & & & & & \\
\hline & & & & & \\
\hline & & & & & \\
\hline & & & & & \\
\hline & & & & & \\
\hline & & & & & \\
\hline & & & & & \\
\hline & & & & & \\
\hline & & & & & \\
\hline & & & & & \\
\hline & & & & & \\
\hline
\end{tabular}




\begin{tabular}{|c|c|c|c|}
\hline & & $\begin{array}{l}\text { Expenditures in first } 12 \text { months of } \\
\text { operation ( } 2006 \text { or } 2008)\end{array}$ & Expenditures in 2010 \\
\hline 9.1 & General operating expenses & $\bullet$ & \\
\hline 9.2 & Source of data (specify) & & \\
\hline 9.3 & $\begin{array}{l}\text { Staff time dedicated to personnel recruitment } \\
\text { Staff member } 1 \text { salary } \\
\text { Staff member } 2 \text { salary } \\
\text { Staff member } 3 \text { salary }\end{array}$ & $\begin{array}{l}\text { 1: days a month } \\
\text { 2: days a month } \\
\text { 3: days a month }\end{array}$ & $\begin{array}{l}\text { 1: days a month } \\
\text { 2: days a month } \\
\text { 3: days a month }\end{array}$ \\
\hline 3.4 & $\begin{array}{l}\text { Personnel recruitment costs (newspaper adverts, } \\
\text { transport, relocation, etc.) }\end{array}$ & $\bullet$ & $\bullet$ \\
\hline 9.5 & OSC space rentals & $\bullet$ & $\bullet$ \\
\hline 9.6 & Water bill & $\bullet$ & $\bullet$ \\
\hline 9.7 & Electricity bill & $\bullet$ & $\bullet$ \\
\hline 9.8 & Telephone bill & $\bullet$ & $\bullet$ \\
\hline 9.9 & Internet connection & $\bullet$ & • \\
\hline 9.10 & Stationery/ postage & $\bullet$ & $\bullet$ \\
\hline 9.11 & Materials production/printing & $\bullet$ & $\bullet$ \\
\hline 9.12 & $\begin{array}{l}\text { External technical assistance (consultants to } \\
\text { support program implementation) }\end{array}$ & • & - \\
\hline 9.13 & $\begin{array}{l}\text { Legal expenses (not related to legal service } \\
\text { provision) }\end{array}$ & $\bullet$ & $\bullet$ \\
\hline 9.14 & $\begin{array}{l}\text { Cleaning materials, toiletries and/or general } \\
\text { services }\end{array}$ & $\bullet$ & $\bullet$ \\
\hline
\end{tabular}




\begin{tabular}{|c|c|c|c|}
\hline & & $\begin{array}{l}\text { Expenditures in first } 12 \text { months of } \\
\text { operation (2006 or } 2008)\end{array}$ & Expenditures in 2010 \\
\hline 9.15 & Motor vehicle spares & - & $\bullet$ \\
\hline 9.16 & Motor vehicle servicing costs & • & • \\
\hline 9.17 & Motor vehicle insurance & - & - \\
\hline 9.18 & Motor vehicle license fees & - & - \\
\hline 9.19 & Repairs to equipment/ office furniture & - & - \\
\hline \multirow[t]{2}{*}{9.20} & Other (specify) & - & $\bullet$ \\
\hline & & KM Per month & KM Per month \\
\hline \multirow[t]{2}{*}{9.21} & Vehicle expenses & & \\
\hline & $\begin{array}{l}\text { Did this data come from log books? } \\
\begin{array}{c}0=\text { no } \\
1=\text { yes }\end{array}\end{array}$ & & \\
\hline A & January & & \\
\hline B & February & & \\
\hline $\mathrm{C}$ & March & & \\
\hline D & April & & \\
\hline$E$ & May & & \\
\hline $\mathrm{F}$ & June & & \\
\hline G & July & & \\
\hline $\mathrm{H}$ & August & & \\
\hline I & September & & \\
\hline$J$ & October & & \\
\hline $\mathrm{K}$ & November & & \\
\hline $\mathrm{L}$ & December & & \\
\hline
\end{tabular}


Appendix 2: OSC Record Review Datasheet

\begin{tabular}{|c|c|c|c|}
\hline \multicolumn{4}{|c|}{ Record identifiers } \\
\hline 1 & OSC name & $\begin{array}{cc}\text { KNH } & \mathbf{1} \\
\text { MRTH } & \mathbf{2} \\
\text { MSF-F } & \mathbf{3}\end{array}$ & [_] \\
\hline 2 & Data collector's name & Name_ & \\
\hline 3 & Today's date & [ & \\
\hline 4 & Time began review & [_/__L] & \\
\hline 5 & Time ended review & [_L_L_ $]$ & \\
\hline 6 & Questionnaire Number & 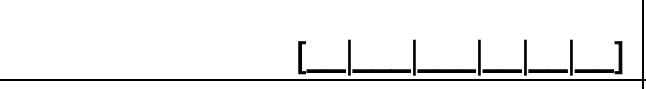 & \\
\hline 7 & What records were consulted for this case? & & \\
\hline & a) Incident Report & \begin{tabular}{cc|} 
Yes & 1 \\
No & 2
\end{tabular} & [_] \\
\hline & b) Case status book & \begin{tabular}{rr|} 
Yes & 1 \\
No & 2
\end{tabular} & [_] \\
\hline & c) Police Medical Report Form & \begin{tabular}{cc|} 
Yes & 1 \\
No & 2
\end{tabular} & [_] \\
\hline & d) Police Case Records & \begin{tabular}{cc|} 
Yes & 1 \\
No & 2
\end{tabular} & [_] \\
\hline & e) Counselor's book & \begin{tabular}{cc|} 
Yes & 1 \\
No & 2
\end{tabular} & [_] \\
\hline & f) Other & specify & [_] \\
\hline & $\begin{array}{l}\text { g) Medical records from hospital or health } \\
\text { clinic }\end{array}$ & \begin{tabular}{cc|} 
Yes & $\mathbf{1}$ \\
No & $\mathbf{2}$ \\
\end{tabular} & [_] \\
\hline & h) Paralegal book & \begin{tabular}{cc|} 
Yes & 1 \\
No & 2
\end{tabular} & [_] \\
\hline
\end{tabular}

SECTION 1: DEMOGRAPHIC DATA

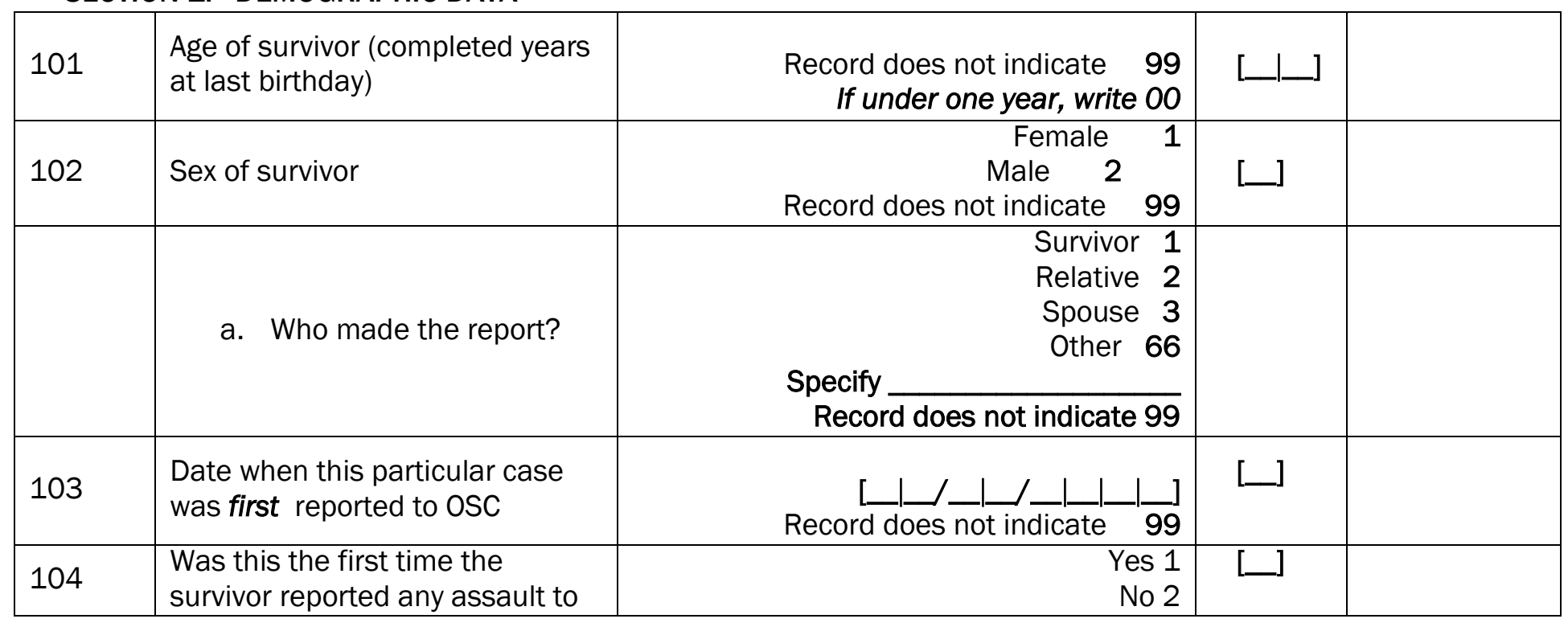




\begin{tabular}{|c|c|c|c|c|}
\hline & this OSC? & Record does not indicate & & \\
\hline & $\begin{array}{l}\text { a. If no, when was the first } \\
\text { time the survivor } \\
\text { reported any assault to } \\
\text { this OSC? }\end{array}$ & $\begin{array}{r}{\left[\_/ \ldots \text { Record does not indicate }\right.} \\
\text { N/A }\end{array}$ & [_] & \\
\hline \multirow[t]{2}{*}{105} & $\begin{array}{l}\text { Was this particular case reported } \\
\text { to the OSC within } 72 \text { hours of } \\
\text { assault? }\end{array}$ & $\begin{array}{rr}\text { Yes } & 1 \\
\text { No } & 2 \\
\text { Record does not indicate } & 99\end{array}$ & [—] & \\
\hline & $\begin{array}{l}\text { a. What was the date of the } \\
\text { assault/incident that this } \\
\text { report pertains to? }\end{array}$ & Record does not indicate & [_] & \\
\hline \multirow[t]{2}{*}{106} & $\begin{array}{l}\text { Where did the survivor report the } \\
\text { case first? }\end{array}$ & $\begin{array}{rr}\text { Police station/post } & 1 \\
\text { Hospital } & 2 \\
\text { Health center } & 3 \\
\text { OSC first point of contact } & 4 \\
\text { Follow-on from court case } & 5 \\
\text { Other } & 66 \\
\text { Specify } & \\
\text { Record does not indicate } & 99\end{array}$ & [_] & \\
\hline & $\begin{array}{l}\text { a. If EVER reported to a } \\
\text { police post, what is the } \\
\text { name of the police } \\
\text { station/post? }\end{array}$ & \begin{tabular}{rr}
\multicolumn{3}{c}{ Name of Police station/post } \\
N/A & 88 \\
Record does not indicate & 99
\end{tabular} & [—] & \\
\hline \multirow[t]{4}{*}{107} & $\begin{array}{l}\text { Type of GBV } \\
\text { (multiple responses possible) }\end{array}$ & \begin{tabular}{lccc} 
Yes No & & & \\
Rape & 1 & 2 & \\
Defilement & 1 & 2 & \\
Physical Violence (non-sex) & 1 & 2 & \\
Property grabbing & 1 & 2 & \\
Record does not indicate & 99 & \\
Other & \multicolumn{2}{c}{66} & \\
Specify & & & \\
Emotional abuse & 1 & 2 & \\
Early marriage & 1 & 2 & \\
Child neglect & 1 & 2 & \\
Child abuse (non-sexual or physical) & 12 \\
Child support & 1 & 2 &
\end{tabular} & $\begin{array}{l}\text { A. [_] } \\
\text { B. [_] } \\
\text { C. [_] } \\
\text { D. [_] } \\
\text { E. [_] } \\
\text { F. [_] } \\
\text { G. [_] } \\
\text { H. [_] } \\
\text { I. [_] } \\
\text { J. [_] } \\
\text { K. [_] }\end{array}$ & \\
\hline & $\begin{array}{l}\text { Was the survivor using alcohol at } \\
\text { the time of the assault/incident? }\end{array}$ & $\begin{array}{ll}\text { Yes } & 1 \\
\text { No } & 2 \\
\text { Record does not indicate } & 99\end{array}$ & [ & \\
\hline & $\begin{array}{l}\text { a. Was the perpetrator } \\
\text { using alcohol at the time } \\
\text { of the assault/incident? }\end{array}$ & $\begin{array}{rr}\text { Yes } & 1 \\
\text { No } & 2 \\
\text { Record does not indicate } & 99\end{array}$ & [ & \\
\hline & $\begin{array}{l}\text { b. Were either the survivor } \\
\text { or the perpetrator using } \\
\text { any other drugs at the } \\
\text { time of the } \\
\text { assault/incident? }\end{array}$ & 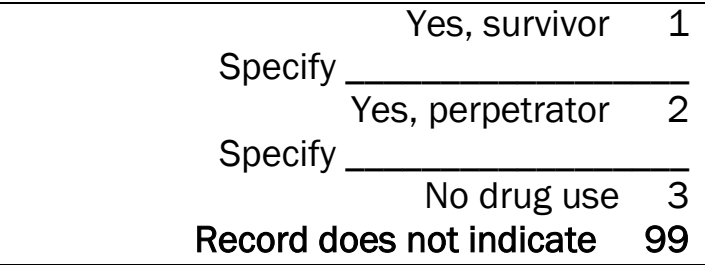 & & \\
\hline 108 & Location of assault/ incident & 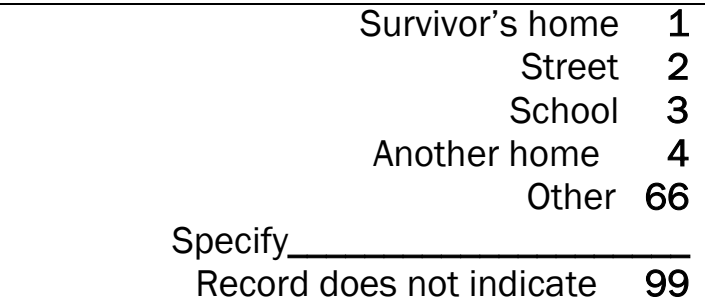 & [ $]$ & \\
\hline
\end{tabular}




\begin{tabular}{|c|c|c|c|c|}
\hline & $\begin{array}{l}\text { a. Province where assault } \\
\text { occurred }\end{array}$ & Name: & [_] & \\
\hline & $\begin{array}{l}\text { b. District where assault } \\
\text { occurred }\end{array}$ & $\begin{array}{l}\text { Name: } \\
\quad \text { Record does not indicate } 99\end{array}$ & [_] & \\
\hline & $\begin{array}{l}\text { c. Town where assault } \\
\text { occurred }\end{array}$ & $\begin{array}{l}\text { Name: } \\
\text { Record does not indicate } \quad 99\end{array}$ & [_] & \\
\hline & $\begin{array}{l}\text { d. Compound where assault } \\
\text { occurred }\end{array}$ & $\begin{array}{l}\text { Name: } \\
\text { Record does not indicate } 99\end{array}$ & [_] & \\
\hline 109 & Sex of perpetrator & $\begin{array}{r}\text { Female } 1 \\
\text { Male } 2 \\
\text { Record does not indicate } \quad 99\end{array}$ & [_] & \\
\hline 110 & $\begin{array}{l}\text { Age of perpetrator (completed } \\
\text { years at last birthday) }\end{array}$ & Record does not indicate $\left[-{ }_{99}\right]$ & [_L_ ] & \\
\hline 111 & $\begin{array}{l}\text { Relationship of perpetrator to } \\
\text { survivor }\end{array}$ & $\begin{array}{r}\text { Father } 1 \\
\text { Mother 2 } \\
\text { Brother } 3 \\
\text { Sister } 4 \\
\text { Uncle } 5 \\
\text { Auntie } 6 \\
\text { Grandfather } 7 \\
\text { Grandmother } 8 \\
\text { No relationship } 9 \\
\text { Husband } 10 \\
\text { Wife } 11 \\
\text { Cousin } 12 \\
\text { Other } 66\end{array}$ & [_] & \\
\hline 112 & $\begin{array}{l}\text { Did the survivor have a } \\
\text { disability? }\end{array}$ & $\begin{array}{rr}\text { Yes } & 1 \\
\text { No } & 2 \\
\text { Record does not indicate } & 99\end{array}$ & [_] & $\begin{array}{l}\text { If no or } 99 \text {, } \\
\text { skip to } \\
\text { section } 2\end{array}$ \\
\hline & $\begin{array}{l}\text { a. What type of disability } \\
\text { did the survivor have? }\end{array}$ & $\begin{array}{r}\text { Blind } 1 \\
\text { Deaf } 2 \\
\text { Mental impairment } 3 \\
\text { Physical impairment } 4 \\
\text { Other } 66\end{array}$ & [_] & \\
\hline & $\begin{array}{l}\text { b. Were any special } \\
\text { provisions made for the } \\
\text { disabled survivor? }\end{array}$ & $\begin{array}{rr}\text { No special provisions made } 1 \\
\text { Sign language interpreter provided } 2 \\
\text { Counselor assisted w/ interview } 3 \\
\text { Other } 66 \\
\text { Specify_ } \\
\text { N/A } & 88 \\
\text { Record does not indicate } & 99\end{array}$ & [_] & \\
\hline
\end{tabular}


Section 2: Medical Information

\begin{tabular}{|c|c|c|c|c|}
\hline 200 & $\begin{array}{l}\text { Are hospital/health facility records } \\
\text { available to review? }\end{array}$ & $\begin{array}{lll}\text { Yes } & 1 \\
\text { No } & 2\end{array}$ & [_] & \multirow{3}{*}{$\begin{array}{l}\text { If no for all, skip } \\
\text { to section } 3 \\
\text { If yes to any, } \\
\text { complete } \\
\text { section } 2\end{array}$} \\
\hline & $\begin{array}{l}\text { a. Is there a Police Medical } \\
\text { Report Form available to } \\
\text { review? }\end{array}$ & $\begin{array}{ll}\text { Yes } & 1 \\
\text { No } & \mathbf{2}\end{array}$ & [_] & \\
\hline & $\begin{array}{l}\text { b. Is there any other source of } \\
\text { medical information } \\
\text { available? }\end{array}$ & $\begin{array}{lll} & \text { Yes } & 1 \\
\text { Write source } & \text { No } & 2 \\
\end{array}$ & [_] & \\
\hline 201 & $\begin{array}{l}\text { Did survivor change clothes/bath } \\
\text { following GBV? }\end{array}$ & $\begin{array}{rr}\text { Yes } & 1 \\
\text { No } & 2 \\
\text { Record does not indicate } & 99\end{array}$ & [_] & \\
\hline 202 & $\begin{array}{l}\text { Was any clothing or debris } \\
\text { collected from survivor's body as } \\
\text { evidence? }\end{array}$ & $\begin{array}{rr}\text { Yes } & 1 \\
\text { No } & 2 \\
\text { Record does not indicate } & 99\end{array}$ & [_] & \\
\hline \multirow[t]{6}{*}{203} & $\begin{array}{l}\text { Is there a copy of the signed police } \\
\text { medical report in the file? }\end{array}$ & 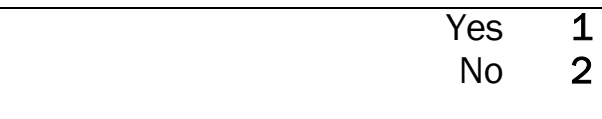 & [_] & \\
\hline & $\begin{array}{l}\text { a. Name of the health facility } \\
\text { where medical report form } \\
\text { was completed (signed by } \\
\text { doctor) }\end{array}$ & $\begin{array}{l}\text { Name of signing health facility } \\
\qquad \text { N/A } 88\end{array}$ & [_] & \\
\hline & $\begin{array}{l}\text { a. Date completed (signed by } \\
\text { doctor) at health facility }\end{array}$ & Record does not indicate & [_] & \\
\hline & $\begin{array}{l}\text { b. Name of police station that } \\
\text { issued the medical report }\end{array}$ & Name of issuing police station & & \\
\hline & form & N/A 88 & & \\
\hline & $\begin{array}{l}\text { c. Date issued from police } \\
\text { station }\end{array}$ & Record does not indicate & [_] & \\
\hline \multirow[t]{2}{*}{204} & $\begin{array}{l}\text { Name of facility where survivor } \\
\text { received medical care }\end{array}$ & Name__ & & \\
\hline & a. Date medical care provided & Record does not indicate $\frac{1}{99}$ & [_] & \\
\hline 205 & $\begin{array}{l}\text { Did survivor experience } \\
\text { penetrative vaginal or anal sexual } \\
\text { assault? }\end{array}$ & $\begin{array}{rr}\text { Yes } & 1 \\
\text { No } & 2 \\
\text { N/A } & 88 \\
\text { Record does not indicate } & 99 \\
\end{array}$ & [_] & $\begin{array}{l}\text { If no, skip to } \\
212\end{array}$ \\
\hline \multirow[t]{2}{*}{206} & $\begin{array}{l}\text { Was a pregnancy test (Gravidex) } \\
\text { conducted? }\end{array}$ & 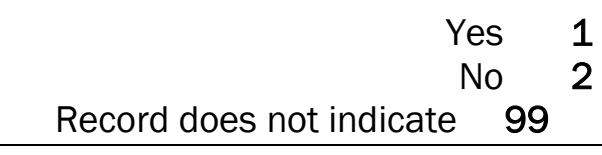 & [ـ] & $\begin{array}{l}\text { If no, skip to } \\
207\end{array}$ \\
\hline & a. What were the results? & $\begin{array}{c}\text { R or } \AA=\text { Reactive (positive) } \\
\text { NR= Non-Reactive (negative) } \\
\text { N/A } 88 \\
\text { Record does not indicate } 99\end{array}$ & [_] & \\
\hline 207 & $\begin{array}{l}\text { Was a Rapid Plasma Reagent } \\
\text { (RPR) test conducted for syphilis? }\end{array}$ & $\begin{array}{rr}\text { Yes } & 1 \\
\text { No } & 2 \\
\text { Record does not indicate } & 99 \\
\end{array}$ & [_] & $\begin{array}{l}\text { If no, skip to } \\
208\end{array}$ \\
\hline
\end{tabular}




\begin{tabular}{|c|c|c|c|c|}
\hline & a. What were the results? & $\begin{array}{cc}\text { R or } \AA=\text { Reactive (positive) } & 1 \\
\text { NR= Non-Reactive (negative) } & 2 \\
\text { N/A } & 88 \\
\text { Record does not indicate } & 99\end{array}$ & [_] & \\
\hline \multirow[t]{2}{*}{208} & $\begin{array}{l}\text { Was a high vaginal swab (HVS) } \\
\text { conducted to detect presence of } \\
\text { sperm? }\end{array}$ & $\begin{array}{rr}\text { Yes } & 1 \\
\text { No } & 2 \\
\text { Record does not indicate } & 99 \\
\end{array}$ & & $\begin{array}{l}\text { If no, skip to } \\
209\end{array}$ \\
\hline & a. What were the results? & $\begin{array}{r}\mathrm{SP}=\text { Spermatoza present } \\
\text { Spermatoza not present (absent } \\
\text { not seen) } \\
\text { N/A } 88 \\
\text { Record does not indicate } \quad 99\end{array}$ & [_] & \\
\hline \multirow[t]{3}{*}{209} & $\begin{array}{l}\text { Was an HIV test conducted? } \\
\text { (Elisa/Determine tests) }\end{array}$ & $\begin{array}{rr}\text { Yes } & 1 \\
\text { No } & 2 \\
\text { Record does not indicate } & 99\end{array}$ & [_] & $\begin{array}{l}\text { If no, skip to } \\
210\end{array}$ \\
\hline & $\begin{array}{l}\text { a. What were the results? } \\
\text { * confirm with the facility if there } \\
\text { are special codes used for the } \\
\text { results }\end{array}$ & $\begin{array}{r}\text { Exposed/ RVD positive (go to b) } \\
\text { Not Exposed/ RVD negative } \\
\text { Status Unknown (maternal or } \\
\text { adult survivor) } \\
\text { N/A } 88 \\
\text { Record does not indicate } 99\end{array}$ & [—] & $\begin{array}{l}\text { if } 2,3,88 \text { or } 99 \\
\text { skip to } 210\end{array}$ \\
\hline & $\begin{array}{l}\text { b. If positive (exposed), was } \\
\text { the survivor referred to } \\
\text { ART/ HART } \\
\text { department/clinic? }\end{array}$ & $\begin{array}{rr}\text { Yes } & 1 \\
\text { No } & 2 \\
\text { N/A } & 88 \\
\text { Record does not indicate } & 99\end{array}$ & [_] & \\
\hline \multirow[t]{2}{*}{210} & Was PEP given to survivor? & $\begin{array}{rr}\text { Yes } & 1 \\
\text { No } & 2 \\
\text { Record does not indicate } & 99\end{array}$ & [_] & $\begin{array}{l}\text { If no, skip to } \\
211\end{array}$ \\
\hline & $\begin{array}{l}\text { a. How many days supply of PEP } \\
\text { was given during the first visit? } \\
\text { *confirm how many pills are given } \\
\text { per day at each facility }\end{array}$ & 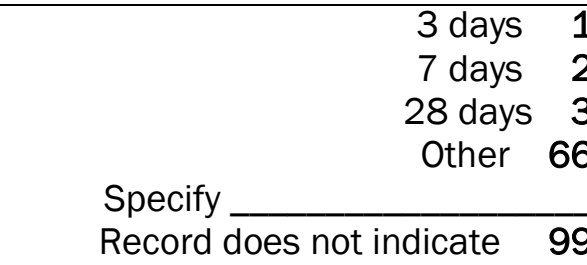 & [_] & \\
\hline 211 & $\begin{array}{l}\text { Was the emergency contraception } \\
\text { pill (ECP) given to survivor? } \\
\text { (Postinor-2, microgynon, } \mathrm{COC}= \\
\text { combined oral contraceptives) }\end{array}$ & $\begin{array}{rr}\text { Yes } & 1 \\
\text { No } & 2 \\
\text { Record does not indicate } & 99\end{array}$ & [_] & \\
\hline 212 & $\begin{array}{l}\text { Did survivor experience physical } \\
\text { violence? }\end{array}$ & $\begin{array}{rr}\text { Yes } & 1 \\
\text { No } & 2 \\
\text { Record does not indicate } & 99\end{array}$ & [_] & $\begin{array}{l}\text { If no, skip to } \\
\text { section } 3\end{array}$ \\
\hline 213 & $\begin{array}{l}\text { What type of physical violence was } \\
\text { experienced? }\end{array}$ & $\begin{array}{rr}\text { Bruises } & 1 \\
\text { Cuts/lacerations } & 2 \\
\text { Broken limbs/bones (\#\#) } & 3 \\
\text { Burns } & 4 \\
\text { Other } & 66 \\
\text { Specify } & \\
\text { N/A } & 88 \\
\text { Record does not indicate } & 99\end{array}$ & [__ ] & \\
\hline 214 & $\begin{array}{l}\text { Did the survivor receive ANY } \\
\text { medical treatment for the physical } \\
\text { violence (i.e. antibiotics, sutures, } \\
I D=\text { drainage, } T T=\text { tetanus toxoid, } \\
\text { pain relief or analgesic (panado), } \\
\text { Hepatitis B) }\end{array}$ & $\begin{array}{rr}\text { Yes } & 1 \\
\text { No } & 2 \\
\text { Record does not indicate } & 99\end{array}$ & [—_] & \\
\hline
\end{tabular}


Section 3: Police/Legal Services

\begin{tabular}{|c|c|c|c|c|}
\hline 300 & $\begin{array}{l}\text { Were police records (apart from Medical } \\
\text { Report Form) available for review? }\end{array}$ & \begin{tabular}{cc|} 
Yes & 1 \\
No & 2
\end{tabular} & [_] & \\
\hline \multirow[t]{4}{*}{301} & $\begin{array}{l}\text { Did a VSU officer meeting with the survivor } \\
\text { during the FIRST visit to the OSC? }\end{array}$ & $\begin{array}{rr}\text { Yes } & 1 \\
\text { No } & 2 \\
\text { Record does not indicate } & 99\end{array}$ & [_] & \\
\hline & $\begin{array}{l}\text { a. Was the survivor referred to meet } \\
\text { with a VSU officer at a later time? }\end{array}$ & $\begin{array}{rr}\text { Yes } & 1 \\
\text { No } & 2 \\
\text { Record does not indicate } & 99\end{array}$ & [_] & \\
\hline & $\begin{array}{l}\text { b. Date survivor FIRST met with VSU } \\
\text { officer }\end{array}$ & Record does not indicate & [_] & \\
\hline & $\begin{array}{l}\text { c. Location where the survivor met the } \\
\text { VSU officer }\end{array}$ & $\begin{array}{lc}\text { This OSC } & 1 \\
\text { Police station/post } & 2 \\
\quad \text { Name_ } & \\
\text { Other Specify } & \\
\text { Record does not indicate } 99 & 99\end{array}$ & [_] & \\
\hline \multirow[t]{4}{*}{302} & $\begin{array}{l}\text { Did a paralegal officer meet with the } \\
\text { survivor during the FIRST visit to the OSC? }\end{array}$ & $\begin{array}{rr}\text { Yes } & 1 \\
\text { No } & 2 \\
\text { Record does not indicate } & 99\end{array}$ & [_] & \\
\hline & $\begin{array}{l}\text { a. Was the survivor referred to meet } \\
\text { with a paralegal at a later time? }\end{array}$ & \begin{tabular}{rr|} 
Yes & 1 \\
No & 2 \\
Record does not indicate & 99 \\
\end{tabular} & [_] & \\
\hline & $\begin{array}{l}\text { b. Date survivor FIRST met with } \\
\text { paralegal }\end{array}$ & Record does not indicate & [_] & \\
\hline & $\begin{array}{l}\text { c. Location where survivor met } \\
\text { paralegal }\end{array}$ & $\begin{array}{lc}\text { This OSC } & 1 \\
\text { Other } & 2 \\
\quad \text { Specify_ } & \\
\text { Record does not indicate } & 99 \\
\end{array}$ & [_] & \\
\hline \multirow[t]{3}{*}{303} & Was a docket opened? & $\begin{array}{rr}\text { Yes (go to 303a) } & 1 \\
\text { No (go to 303b) } & 2 \\
\text { Record does not indicate } & 99\end{array}$ & [_] & \\
\hline & a. If yes, at what police station? & Name $\overline{\text { Record does not indicate } \quad 99}$ & [_] & \\
\hline & b. If no, why not? & $\begin{array}{cr}\text { Case resolved at OSC } & 1 \\
\text { Other } & 66 \\
\text { Specify } & \\
\end{array}$ & [_] & $\begin{array}{l}\text { Skip to } \\
\text { section } 4\end{array}$ \\
\hline 304 & $\begin{array}{l}\text { Did the police take a statement from the } \\
\text { survivor? }\end{array}$ & $\begin{array}{rr}\text { Yes } & 1 \\
\text { No } & 2 \\
\text { Record does not indicate } & 99 \\
\end{array}$ & [_] & \\
\hline 305 & $\begin{array}{l}\text { Did the police take statements from at least } \\
1 \text { other witness? }\end{array}$ & \begin{tabular}{rr|} 
Yes & 1 \\
No & 2 \\
Record does not indicate & 99 \\
\end{tabular} & [_] & \\
\hline 306 & $\begin{array}{l}\text { Did the police physically visit the crime } \\
\text { scene? }\end{array}$ & $\begin{array}{rr}\text { Yes } & 1 \\
\text { No } & 2 \\
\text { Record does not indicate } & 99\end{array}$ & [_] & $\begin{array}{l}\text { If no, skip to } \\
308\end{array}$ \\
\hline
\end{tabular}




\begin{tabular}{|c|c|c|c|c|}
\hline 307 & $\begin{array}{l}\text { Did the police collect at least } 1 \text { piece of } \\
\text { evidence from the crime scene? }\end{array}$ & $\begin{array}{rr}\text { Yes } & 1 \\
\text { No } & 2 \\
\text { N/A } & 88 \\
\text { Record does not indicate } & 99\end{array}$ & [_] & \\
\hline & a. If yes, what type of evidence? & Indicate type of evidence & & \\
\hline \multirow[t]{5}{*}{308} & Did the police arrest the perpetrator? & $\begin{array}{rr}\text { Yes } & 1 \\
\text { No } & 2 \\
\text { Record does not indicate } & 99\end{array}$ & [_] & $\begin{array}{l}\text { If no, skip to } \\
309\end{array}$ \\
\hline & a. What was the date of arrest? & $\begin{array}{r}{[-1 / A} \\
\text { Record does not indicate }\end{array}$ & & \\
\hline & $\begin{array}{l}\text { b. How many days elapsed from first report to } \\
\text { OSC and arrest? }\end{array}$ & $\begin{array}{rr}\text { Number of days } \\
\text { N/A } & \mathbf{8 8} \\
\text { Record does not indicate } & 99\end{array}$ & [_] & \\
\hline & c. How long was the perpetrator held in cells? & $\begin{array}{rr}\text { Number of days } & \\
\text { N/A } & \mathbf{8 8} \\
\text { Record does not indicate } & 99\end{array}$ & [_] & \\
\hline & d. Was the perpetrator released on bail? & $\begin{array}{rrr}\text { Yes } & 1 \\
\text { No } & 2 \\
\text { Record does not indicate } & 99 \\
\text { Amount of bond } & \text { Ksh }\end{array}$ & [_] & \\
\hline 309 & Was the case taken to court? & $\begin{array}{rr}\text { Yes (go to 311) } & \mathbf{1} \\
\text { No (go to 310) } & \mathbf{2} \\
\text { Record does not indicate } & 99\end{array}$ & {$[-]$} & \\
\hline 310 & Why was case not taken to court? & $\begin{array}{rr}\text { Survivor did not want } & 1 \\
\text { Could not find perpetrator } & 2 \\
\text { Matter resolved at OSC } & 3 \\
\text { Survivor never returned } & 4 \\
\text { Case recommended for court but } \\
\text { no further record } & 5 \\
\text { Other } & 66 \\
\text { N/A } & 88 \\
\text { Record does not indicate } & 99\end{array}$ & [_] & $\begin{array}{l}\text { Skip to } \\
\text { section } 4\end{array}$ \\
\hline \multirow[t]{2}{*}{311} & $\begin{array}{l}\text { Did the survivor receive at least } 1 \text { session of } \\
\text { pre-court counseling from the paralegal? }\end{array}$ & $\begin{array}{rr}\text { Yes } & 1 \\
\text { No } & 2 \\
\text { N/A } & 88 \\
\text { Record does not indicate } & 99\end{array}$ & [_] & \\
\hline & a. If yes, number of counseling sessions & 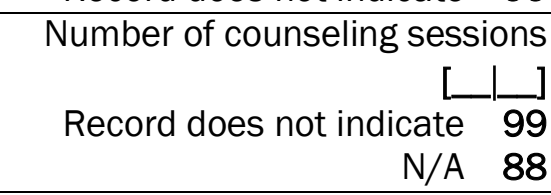 & & \\
\hline 312 & Name of Court & & [_] & \\
\hline & & Record does not indicate 99 & & \\
\hline 313 & Sex of Judge & $\begin{array}{rr}\text { Female } & 1 \\
\text { Male } & 2 \\
\text { N/A } & 88 \\
\text { Record does not indicate } & 99\end{array}$ & [_] & \\
\hline
\end{tabular}




\begin{tabular}{|c|c|c|c|c|}
\hline 314 & Date of first hearing & $\begin{array}{r}\text { Record does not indicate } \\
\text { N/A } 88\end{array}$ & [_] & \\
\hline \multirow[t]{2}{*}{315} & Number of times postponed & $\begin{array}{rr}\text { Number of postponements } & \\
\text { N/A } & 88 \\
\text { Record does not indicate } & 99\end{array}$ & [___ & \\
\hline & a. Date of last hearing & $\begin{array}{l}\text { Record does not indicate } \\
98\end{array}$ & [_] & \\
\hline 316 & Has the court case been completed? & $\begin{array}{rr}\text { Yes } & 1 \\
\text { No } & 2 \\
\text { N/A } & 88 \\
\text { Record does not indicate } & 99\end{array}$ & [_] & $\begin{array}{l}\text { If no, skip to } \\
318\end{array}$ \\
\hline \multirow[t]{3}{*}{317} & What was the outcome of the case? & $\begin{array}{cr}\text { Dismissed } & 1 \\
\text { Perp found guilty } & 2 \\
\text { Perp found innocent } & 3 \\
\text { Other } & 66 \\
\text { Specify } & \text { N/A } \\
\text { Record does not indicate } \quad 98\end{array}$ & [_] & \\
\hline & $\begin{array}{l}\text { a. If case was dismissed, what were the } \\
\text { reasons for dismissal }\end{array}$ & 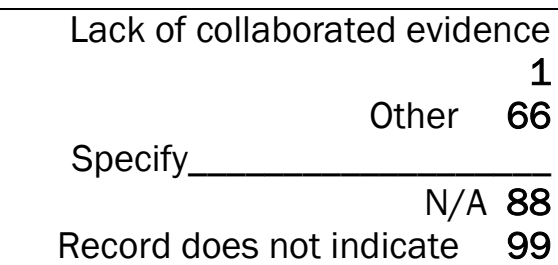 & [_] & \\
\hline & $\begin{array}{l}\text { b. If the perpetrator was found guilty, } \\
\text { what was the sentence? }\end{array}$ & $\begin{array}{r}\text { Number of years [_] } \\
\text { Number of Months [ } \\
\text { Specify } \\
\text { Write 'Ll' for life imprisonment } 66 \\
\text { N/A 88 } \\
\text { Record does not indicate } \\
999\end{array}$ & [_] & \\
\hline \multirow[t]{3}{*}{318} & $\begin{array}{l}\text { Was case withdrawn once it was entered into } \\
\text { court? }\end{array}$ & $\begin{array}{r}\text { Yes 1 } \\
\text { No 2 } \\
\text { N/A 88 } \\
\text { Record does not indicate } \quad 99\end{array}$ & [_] & $\begin{array}{l}\text { If no, skip to } \\
\text { section } 4\end{array}$ \\
\hline & a. Reason for withdrawal & $\begin{array}{rr}\text { Perpetrator is bread winner } & 1 \\
\text { Perpetrator is a relative } & 2 \\
\text { Survivor not happy with court } \\
\text { process } & 3 \\
\text { Settled out of court } & 4 \\
\text { Other } 66 \\
\text { Specify_ N }\end{array}$ & [_] & \\
\hline & $\begin{array}{l}\text { b. How many times was the case heard } \\
\text { before withdrawal? }\end{array}$ & $\begin{array}{r}\text { After } \\
\left(\text { e.g., } 4^{\text {th }}\right) \\
\text { number } \\
\text { N/A } 88 \\
\text { Record does not indicate } \quad 99\end{array}$ & [_] & \\
\hline
\end{tabular}


Section 4: Psychosocial support

\begin{tabular}{|c|c|c|c|c|c|}
\hline 401 & $\begin{array}{l}\text { Did a counselor meet with the } \\
\text { survivor during the FIRST visit } \\
\text { to this OSC? }\end{array}$ & Yes & $\begin{array}{r}1 \\
\text { No } \\
2 \\
99\end{array}$ & [_] & \\
\hline 402 & $\begin{array}{l}\text { Was the survivor referred to a } \\
\text { safe house or shelter (e.g. CIC } \\
\text { or women's shelter)? }\end{array}$ & Yes & $\begin{array}{r}1 \\
\text { No } \\
2 \\
99\end{array}$ & [_] & \\
\hline 403 & $\begin{array}{l}\text { Was the survivor referred to a } \\
\text { survivor's group/network? }\end{array}$ & Yes & $\begin{array}{r}1 \\
\text { No } \\
2 \\
99\end{array}$ & [_] & $\begin{array}{l}\text { If no, skip to } \\
\text { section } 5\end{array}$ \\
\hline \multirow[t]{2}{*}{404} & $\begin{array}{l}\text { Did the survivor attend at } \\
\text { least } 1 \text { survivor's group } \\
\text { meeting? }\end{array}$ & Yes & $\begin{array}{r}1 \\
\text { No } \\
2 \\
99\end{array}$ & [_] & \\
\hline & $\begin{array}{l}\text { a. In total, how many } \\
\text { survivors groups meetings } \\
\text { were attended? }\end{array}$ & $\begin{array}{l}\text { Number of meetings } \\
\text { Record does not indicate }\end{array}$ & $\overline{99}$ & [_] & \\
\hline
\end{tabular}

Section 5: Follow-up care

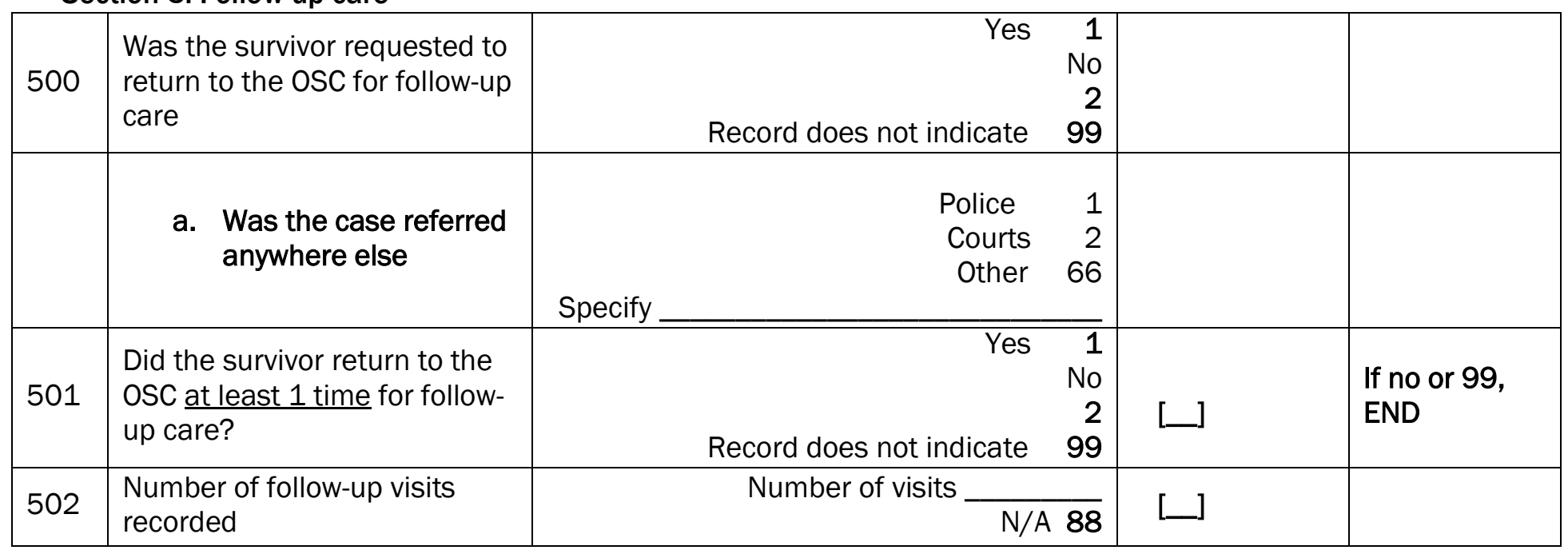




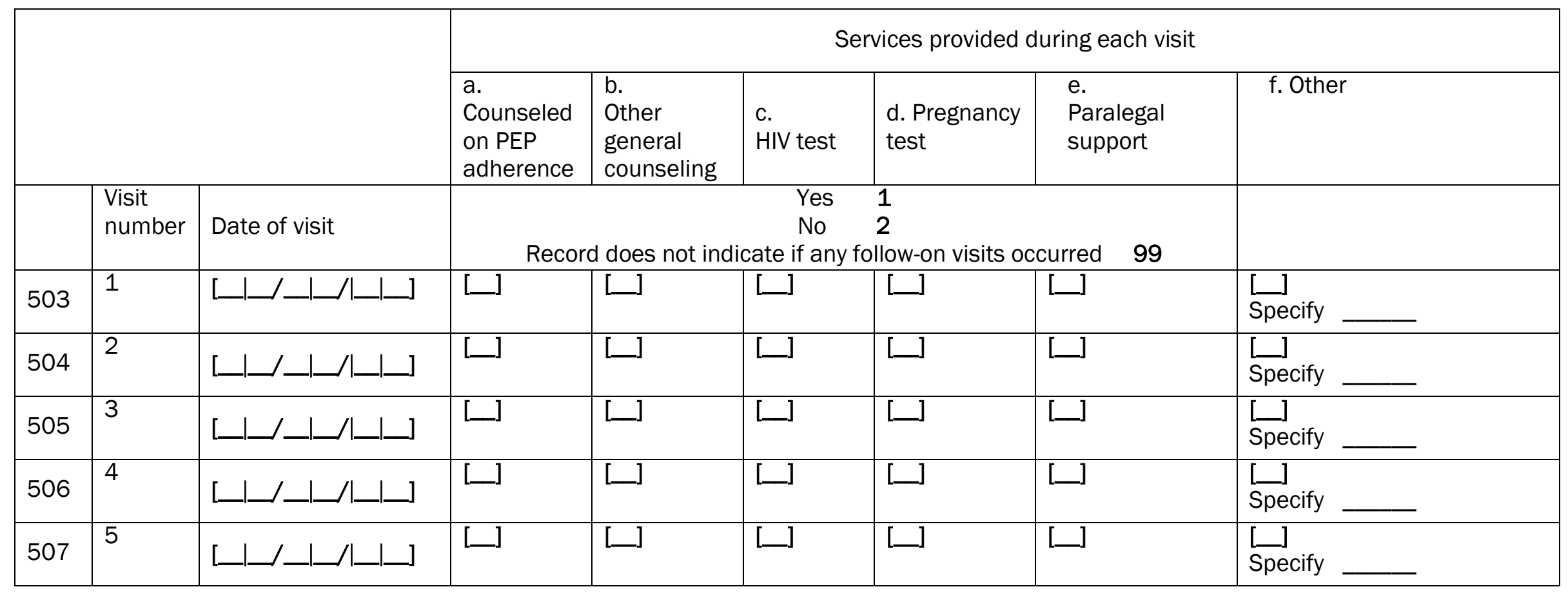

Other notes on client records/ case: 


\section{Appendix 3: Guide for Key Informant Interviews with Program Managers and Stakeholders}

\section{NOTE TO THE FACILITATOR:}

After completing informed consent procedures, the interviewer will conduct a semi-structured discussion with the key informant using the following questions as a guide. Prompting questions will be used to elicit an open-ended response, which can then be directed using probing questions as needed.

The note taker should include the following information at the beginning of each session's transcript.

\begin{tabular}{|c|c|}
\hline Interview date & $\overline{\mathrm{DD}} / \overline{\mathrm{MM} / \mathrm{YY}}$ \\
\hline $\begin{array}{l}\text { Respondent type (circle } \\
\text { letter) }\end{array}$ & $\begin{array}{l}\text { a. Donor } \\
\text { b. OSC program manager (HQ) } \\
\text { c. OSC center manager (on-site) } \\
\text { d. Health facility head/ in-charge } \\
\text { e. Doctor } \\
\text { f. Nurse } \\
\text { g. Paralegal } \\
\text { h. VSU officer } \\
\text { i. Counselor } \\
\text { j. National government representative } \\
\text { k. Magistrate } \\
\text { l. Justice NGO }\end{array}$ \\
\hline OSC Affiliation & $\begin{array}{ll}\text { a. } & \text { KNH } \\
\text { b. } & \text { MRTH } \\
\text { c. } & \text { MSF-France } \\
\text { d. } & \text { All sites }\end{array}$ \\
\hline Interviewer name & \\
\hline Note-taker name & \\
\hline Location of Interview & \\
\hline Start time & $\overline{\mathrm{HH}} / \overline{\mathrm{MM}}$ \\
\hline End time & $\overline{\mathrm{HH}} / \overline{\mathrm{MM}}$ \\
\hline
\end{tabular}




\section{Questions for Key Informant Interviews with Program Managers and Stakeholders}

Informational statement read by the interviewer:

Today we would like to talk to you about the set-up and services provided by one-stop centers (OSCs) for responding to gender-based violence. In Kenya, there are over 20 such OSCs currently in operation. This study is looking at 3 of these centers (KNH, MRTH, and MSF- France) to better understand the strengths and challenges associated with different approaches to the OSC model. This study is also being conducted in Zambia, and the results from both countries will be used to inform GBV programs in other countries.

You have been selected for this interview because you (or your organization) have been involved in the operation of these centers in this country.

1. Are you familiar with the three OSCs involved in this study?

- Which, if any, of the three OSCs involved in this study do you work with/ are you most familiar with?

- Note to interviewer: some national-level participants may not be involved with one specific site, but will rather be able to comment on the approach in general. The questioning for these respondents will need to be general, but the interviewer is urged to focus questioning on the three facilities included in this study, if possible.

2. What is your particular involvement with the OSCs in Kenya [or the center that the respondent is most familiar with]?

3. In your opinion, what is the value of providing GBV care in a OSC setting?

- What are the core services provided at the OSC that you are most familiar with?

Overall assessment of OSC functionality

4. Thinking specifically about [insert name of OSC respondent works at or is most familiar with], how successful do you think this OSC has been in meeting all the different needs of a GBV survivor in a coordinated, comprehensive manner?

- Are there any differences between the quality of clinical, police/legal, or social support (counseling) services provided at this OSC?

- Is one service stronger than the others? Why do you think that is?

- How well are all these services integrated? Do the different providers/sectors work well together?

- What could be improved about this coordination?

5. Data indicates that a large proportion of those who report to OSCs are children. Do you think that the services provided at the OSCs do a good enough job at addressing the needs of these young survivors?

- What special provisions are in place for child survivors?

- In your opinion, how well do these provisions work?

- What else needs to be done to improve care for children?

6. In general, do you think survivors who report to this OSC receive quality clinical care?

- What are the gaps in these services?

- What are the strengths?

- Probe for issues related to: policies and guidelines, facility capacity, providers, community demand for services

- What can be improved?

- How well do they address the medical needs of children? (if not mentioned) 
7. In general, do you think that the survivors who report to this OSC receive necessary support from the police?

- What are the gaps in these services?

- What are the strengths?

- Probe for issues related to: policies and guidelines, facility capacity, providers, community demand for services

- What can be improved?

- How well do police handle cases involving children? (if not mentioned)

8. In general, do you think that the survivors who report to this OSC receive the support they need to be able to successfully pursue their case in court?

- What are the gaps in these services?

- What are the strengths?

- Probe for issues related to: policies and guidelines, facility capacity, providers, community demand for services

- What can be improved?

- How well do OSCs prepare children (and their parents) for successful court hearings, including both the collection of evidence and court appearances?

9. In general, do you think that the survivors who report to this OSC receive the social support they need to recover psychologically?

- What are the gaps in these services?

- What are the strengths?

- Probe for issues related to: policies and guidelines, facility capacity, providers, community demand for services

- What can be improved?

- How well do the OSCs address the needs of children and their parents?

Potential for sustainability and replicablity

10. Ideally, what are the next steps for this OSC?

11. What organizations currently provide financial support for this OSC?

- Can the OSC sustain its operations without this support?

12. In your opinion, what are the elements of the OSC that are most sustainable in the longterm?

- What are the least sustainable elements?

- What can government or partners do to ensure the sustainability of this OSC?

13. In your opinion, do we need more OSCs in Kenya or do we have enough?

- So far OSCs have only been introduced in urban or peri-urban areas. Do you think that it could be successful in rural areas? Why or why not?

- Could it work in rural health centers?

14. Do you have anything else to add?

Thank you for your time and valuable contributions. 


\section{Appendix 4: In-depth Interview Guide for Survivors}

\section{NOTE TO THE FACILITATOR:}

After completing informed consent procedures, the interviewer will conduct a semi-structured discussion with the survivor using the following questions as a guide. Prompting questions will be used to elicit an open-ended response, which can then be directed using probing questions as needed.

The note taker should include the following information at the beginning of each session's transcript.

\begin{tabular}{|c|c|}
\hline Interview date & $\overline{\mathrm{DD}} / \overline{\mathrm{MM}} / \overline{\mathrm{YY}}$ \\
\hline Respondent type (circle letter) & $\begin{array}{l}\text { a. GBV survivor } \\
\text { b. Parent of GBV survivor }\end{array}$ \\
\hline Respondent's age & (years) \\
\hline Respondent's gender & $\begin{array}{ll}\text { a. } & \text { Male } \\
\text { b. } & \text { Female }\end{array}$ \\
\hline OSC Affiliation & $\begin{array}{ll}\text { a. } & \text { KNH } \\
\text { b. } & \text { MRTH } \\
\text { c. } & \text { MSF-France }\end{array}$ \\
\hline Interviewer name & \\
\hline Note-taker/ counselor name & \\
\hline Location of Interview & \\
\hline Start time & $\overline{\mathrm{HH}} / \overline{\mathrm{MM}}$ \\
\hline End time & $\overline{\mathrm{HH}} / \overline{\mathrm{MM}}$ \\
\hline
\end{tabular}


Informational statement read by the interviewer:

Thank you for agreeing to speak with us today. We are conducting a review of one-stop centers (OSC) that provide care to survivors of gender-based violence. Our objective is to understand what is working well in the OSC and what can be improved. As someone who received services from one of these facilities, your opinion is very valuable to us.

Today we will ask you questions only about the services you received from the OSC (insert name of specific facility), and not about the GBV you experienced. If at any time these questions become too difficult to answer, you are welcome to end the interview. My colleague (insert notetaker, counselor's name) is a trained counselor, so she can provide support if you need it. We can also refer you to other professionals who can help.

1. Now, if it is ok with you, we'd like to begin by talking about your FIRST visit to the one-stop center.

- Do you remember the day of the week that you went to the OSC? What time of day was it?

- Probe: did they report on a weekend or night? If so, was the OSC open, did they have to wait until the OCS opened?

- When you arrived, who were you greeted by? What did they tell you?

- What was the reason you sought care at the OSC?

- Probe for: rape, defilement, domestic violence, other

- How long did you have to wait before you received services?

- Did this seem like it was too long or just the right amount of time?

- What happened next, can you briefly review the different steps that you were taken through from beginning to end?

- In total, how much time did you spend in the OSC from beginning to end of your first visit?

- Did this seem like it was too long or just the right amount of time?

- Were you asked to pay for any services?

- What services and how much?

2. After that first visit, did you return to the OSC for any other services?

- What services did you return for?

- Probe for: survivors groups, follow-up medical care or testing, police matters, meetings with paralegals, meetings with counselors

- How many times did you return?

- Would you have liked to return to the OSC more times than you did?

- If yes, what kept you from returning?

- Probe for: limited transport, community stigma, partner didn't approve/know

3. Now I would like to ask you some questions about the medical care you received from the OSC.

- During your first visit to the OSC, did you receive any medical care?

- If not during your first visit, did you ever receive medical care from the OSC? (if no, skip this section)

- Where was the medical care provided? Did you feel the room protected your privacy?

- Did you see a doctor at any time during your first visit to the OSC?

- Did you feel the doctors and nurses were respectful to you?

- How long did the medical exam take?

- Did this seem like it was too long or just the right amount of time?

- During your first visit, did you receive a drug called emergency contraception (EC) which is used to prevent pregnancy? 
- If no, did the provider discuss it with you?

- If yes, did you take both pills? Did you experience any side-effects?

- Did you become pregnant soon after? Do you think that pregnancy was caused by the GBV you experienced?

- During your first visit, did you receive a drug to prevent HIV transmission (called PEP)?

- If no, did the provider discuss it with you?

- If yes, how many pills were you given to take home with you?

- Did the provider take enough time to explain how the drug works, its side effects and answer your questions?

- Did you experience any side-effects? What were they?

- Did you take the drug for all 28 days?

- After the first visit, did you return to the OSC for any more health services?

- What services were they?

- How would you improve the medical care you received from the OSC?

-

4. Now I would like to ask you some questions about the counseling and social services you received from the OSC.

- During your first visit to the OSC, did you meet with a counselor?

- If not on your first visit, did you ever meet with a counselor? (if no, skip this section)

- Where did you meet with the counselor? Did you feel the room protected your privacy?

- Did you feel that the counselor was respectful to you?

- Did you feel that it safe for you to go back to your own home at the time of your first visit to the OSC?

- If not, were the OSC staff able to find you alternate accommodation?

- Where was this accommodation located? How long did you stay there? What did you do after you left?

- What services did the counselor provide during your first visit?

- Probe for: counseling, referrals to other services, provided clothes/food, etc.

- During your first visit, were you invited to participate in survivors groups? If no, when were you invited to participate?

- How many survivors group meetings have you attended?

- Do you feel that survivors groups are useful for the participants?

- Have you ever returned to the OSC for any additional social services or counseling (apart from survivors groups)?

- How many return visits have you made to see social services or counseling?

- What services did you receive?

- How would you improve the counseling and social services you received from the OSC?

5. Now I would like to ask you some questions about the police services you received from the OSC.

- During your first visit to the OSC, did you meet with a VSU officer?

○ If not on the first visit, did you ever meet with a VSU officer? (if no, skip this section)

- Where did you meet with the VSU officer? Did you feel the room protected your privacy?

- Did the VSU officer take a statement from you?

- Did you feel that the VSU officer was respectful to you?

- Were you given a police medical report form for the doctor to sign?

- Did the doctor sign the report form?

- Was the signed report form returned to the police?

- If not, did you keep the form? Why? 
- Did you decide to pursue the case in court? Why or why not?

- To the best of your knowledge, did the police:

- Ever visit the scene of the crime?

- Take a statement from other witnesses?

- Take a statement from the perpetrator?

- Was the perpetrator arrested? How long was the perpetrator in the cells?

- After the first visit, did you return to the OSC to meet with the VSU officer?

- Did you meet with the VSU officer at the police station?

- How many times?

- What was the purpose of these meetings?

- How would you improve the police services you received from the OSC?

6. Now I would like to ask you some questions about the legal services you received from the OSC.

- During your first visit to the OSC, did you meet with a paralegal?

$\circ$ If not on your first visit, did you ever meet with a paralegal?

- How many times in total have you met with a paralegal from the OSC?

- Where did you meet with the paralegal? Did you feel the room protected your privacy?

- What services did the paralegal provide?

- Do you feel that the paralegal was respectful to you?

- How would you improve the legal services provided at the OSC

- Did you decide to take your case to court? Why or why not?

- If yes, do you feel that you were adequately prepared for court by the paralegal?

- Do you think that the police collected enough evidence to adequately prosecute the case?

- Some people say that they find the court hearing intimidating. Did you find your court hearing intimidating?

- Were you happy with the outcome?

- What could have been done to improve your experience with the court?

7. Were you referred by any care provider in the OCS to any additional services that not offered at the OSC?

- What were these services?

- Did you seek them?

- Why or why not?

8. Overall, are you happy with the care and services provided to you at the OSC?

- Do you have any recommendations for improving services?

9. Do you have any other comments? 